\title{
LAUP- $95-1282$
}

The:

PRODUCTION OF AN ENGLISH/ROSSIAN GLOSSARY OF TERYINOLOGY FOR RUCLEAR matERIALS CONTROL AND ACCOUNTING

\section{RECEIVED \\ MAY 08 1995 . \\ OSTI}

Author(s): Sergej Schachowskof and Hastings A. Smf th, Jr.

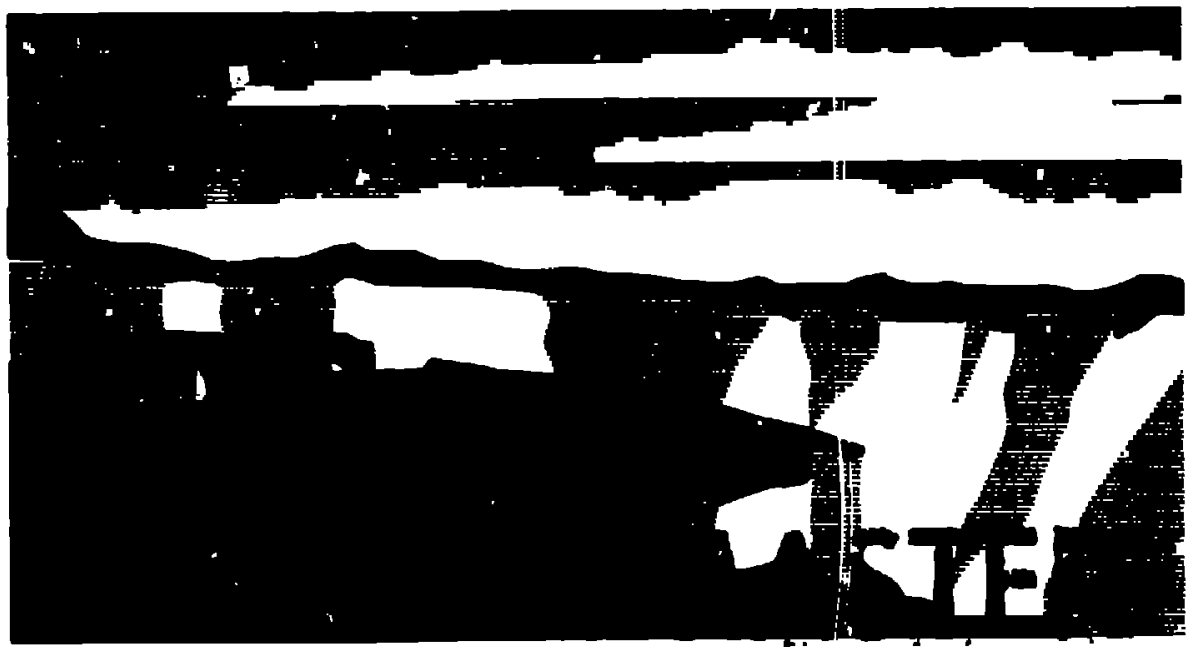

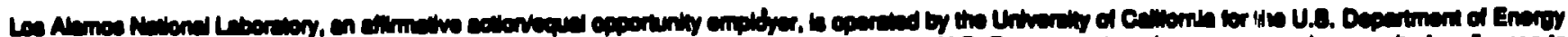

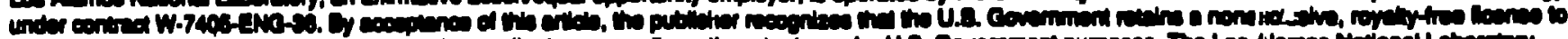

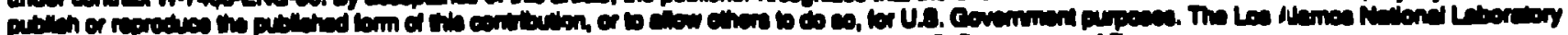

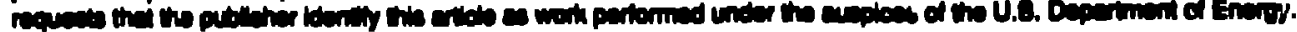




\title{
PRODUCTION OF AN ENGLISH/RUSSIAN AND RUSSIAN/ENGLISH GLOSSABY OF TERMINOLOGY FOR NUCLEAR MATERIALS CONTROL AND ACCOUNTING
}

\author{
Sergej Schachowskoj (Translation and Interpretation Service). \\ Hastings A. Smith, Jr. (Nonp.oliferation \& Internarional Security Division) \\ Los Alamos National Laboratory
}

\begin{abstract}
Background
The program plans for Former Soviet Union National Nuclear Materials Control and Accounting (MC\&A) Systems Enhancements call for the development of an English/Russian Glossary of MC\&A terminology. This glossary was envisioned as an outgrowth of the many interactions. training sessions, and other talking and writing exencises that would transpire in the course of carrying out these programs. This repor summarizes the starus of the production of this glossary. the most recent copy of which is attached to this report
\end{abstract}

\section{Resources Used}

The early stages of the development of this glossary included assembly of ofter-encountered jargon and other MC\&A terminology. as well as the International Atomic Energy Agency (LAEA) glossary of Safeguards Terms.' In the past year, the Los Alamos Translation and Interpretation Service has been formally tabulating such terminology as they have encountered it in servicing our translation and interpretation needs. In addition. we have involved our Russian colleagues to help us assess our Russian usage in this tochnical area. We have received detailed feedback on earlier versions oi this glossary from specialists at Elekrrostal Machine-Building Plant and Arzamas-16 (both in Moscow). The attached glossary of MC\&A terms is the most recent version of this compilation. in which all Russian comments received to dare have been incorporated. However. the glossary is considered a living document, subject to further refinements. as more interactions occur and more feedback is received.

\section{Status of the Glossary}

The glossary of MC\&A terms artached to this report is a sub-glossary of a larger compiiation of terminology in more than 20 ropical areas in which LANL has been interacting with Russian specialists. (Other technical areas in which Russian/English terminology has been correlated a include physical protection. pulsed power. safety. etc.i

The glossary contents exist as records on a flar-file data base under FileMaker ProTM software. Each record contains

- the English and Russian term.

- the subject arears 1 in which it is used.

- the projectisi on which the term has been used. and

- a description of the context in which the term is typically used.

The entries can be alphabetized in either Russian or English. and sub-glossaries can be frinted. based on choices of suijects or projects. The printed glossary attached to this repor contains over 900 terms associated with MC\&A and is prinied in both Russian/English and English/Russian form.

I "LAEA Safeguards Glossary. 1987 Edution-"- IAEA Repon IAEASGG/NF/l (Rev. 1 ) i1987, 


\title{
Utilization of Glosenry to Date
}

Thx: glossary has been transmitted to the working levels of our Russian and FSU interactions throughout its life.

- George Ruenycc, ; $D O E N N$-4) has received a copy for his use in FSU interactions.

- Interpreters on Russian MC\&A and Physical Protection trips [OSIA, DOS] have received the document to help them prepare for the exchanges.

- Both the translowors and Russian-speaking US specialists at Los Alamos have used the glossary as they prepare training and other written materials for relevant projects.

\section{Future Steps}

Now that the glossery has reached some measure of completeness, it is time to issue it, so that more users can benefit from its contents and can comment further to improve its value. This report, along with a more formal publication of the glossary to follow, serves that purpose.

Improvements or additions to the glossary are always we'come. Send the appropriate information to Sergej Schachowskoj through one of the following means:

\author{
Mailing Address: Los Alamos National Laboratory, P. O. Box 1663 Mail Stop M704, \\ Los Alamos, NM 87545 USA \\ Fax: (505) 665-3891 \\ e-mail: sergej@lanl.gov
}

\section{DECLAMMIR}

This report was prepared as an ecoount of work eponeored by an apency of the United State Government. Netther the United Sutes Government nor any apency thereor, bor uny of thetr

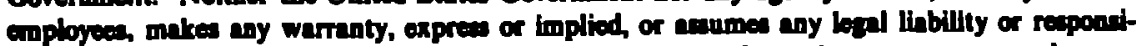
billity for the eccuracy, completenem, or uefulnees of any information, apparatus, produch, of proces dieclond, of represents that the use would not infringe privatoly owned righte Refer-

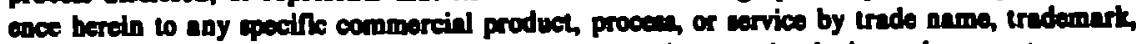
manufecturor, or otherwte does not necemarily constitute or tmply it endornement, recommendation, of favoring by the United States Covernment or any apency thereof. The riom

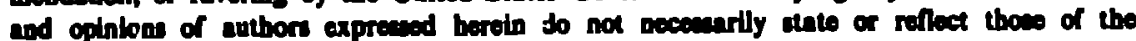
United States Government or any apeney theroof. 


\title{
Los Alamos \\ National Laboratory
}

\section{English/Russian and Russian/English Glossary of MC.\&A Terminology}

\author{
Glossary of Terms and Acronyms
}

The following material contains over 950 terms and acronyms associated with nuclear material control and accounting for safeguards and nonproliferation. This document is organized as follows:

- English/Russian Glossary of Terms and Acronyms

- Russian/English Glossary of Terms and Acronyms

- English/Russian Glossary of Acronyms

- Russian/English Glossary of Acronyms

Where an example of typical usage or other comment is avaliable on an entry, that information has been ertered below the entry, slightly indented.

The production of this glossary was supported by the US Department of Energy, Intermational Safeguards Division, through the many interactions of US speciallsts and Interpreters with the technical experts and interpreters from Russia, Kazakhstan, and the Ukraine. This document indicates the present status of the development of this glossary, which will evolve further as more interactions take place.

Comments on, corrections to, and suggested changes or additions to the glossary are most welcome. Please address comments to Sergej Schachowsko] at one of the following addresses:

\author{
Sergej Schachowsko] \\ Translation and Interpretation Service \\ Los Alamus National Laboratory \\ Post Offico Box 1663 Mall Stop M704 \\ Los Alamos, New Mexico 87545 USA
}

Phone: (505) 665-8376

Fax: (505) 665-3891

ө-mail: sergej lanl.gov 


\section{ENGLISH - RUSSIAN GLOSSARY}

mcen Coneral Gloseary

Los Alamos National Laboratory - Translation and Imterpretetion Sorvice

Aprill 6, 19as

absorb

accessorles

accidental loss

account

account balance

account total

accountablilty

accountability measurement

Naceuremem detn that moy be ueed for maturial cecounting.

accountancy

accountancy detection probablity

accounting

accounting records

accounting report

accuracy

accuracy of measurement

ACDA

Arms Control a Diaamamens Agency

active, fast mode insert

actlve measurement norлouнtь

комплектуочие

esapuLнea notepa

учетная sankcb

учетный баланс материала

суммарный учет метеривла

подотуетность

учетное измерение

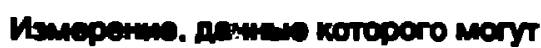

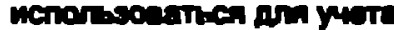

практика учета

веронтность обнарукения мерами учетв

учет

материалоно - балансовые

учетные дпкументы

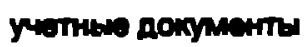

учетные документы

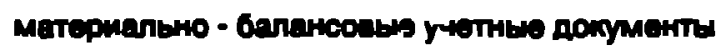
oтuet no yuety

точность

точность измерөния

AKBP

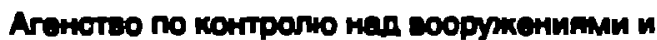
pasopy

вктивная вставка, с быстрыми нөйтронами

вктивное измерение 


\author{
active neutron Interrogation \\ active will colncidence counter \\ Awce \\ actlve-fast mode \\ actlve-thermal mode \\ actual Inventory difference
}

mest caneral Glosecery

Los Alanos Mational Leboretiony - Transiation end Interpretation Eorvico

ADC

melog-to-dighel corverter

adjustment

admin istrative check

administratlve unit

administr'stive unit inventory commission

ADU

ADU cake

advanced gas cooled reactor

AGR

AGR

advanced gas cooled reactor

agraement

A formal agreoment.

alarm Iimits
April 6, 1000

облученіле активными нейтронами

активный колодезный счетчик совпадений

актианый режим работы на быстрых нейтронах

активный режим работы не тепловых Hеңтронах

Фактическая инвентарная разность

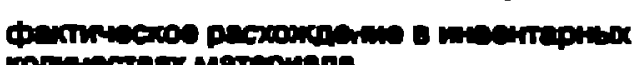

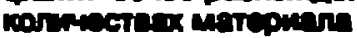

аналогово - цифровой

переобразователь

уточнение

административная проверка

подразделеіияе

инвентаризационная комиссия

позразделения

диуранат вммиака

диуранат аммиака

усовершенствованный

газоохлаждаемый реактор

усовершенствованный

газоохлаждаемый рөактор

соглашение

предельные значөние пля ПрАЕөдения в дөйствие Сигнала тревоги

nорогоане значеми

пороговые значения для приведения в дөйствие сигнала тревоги

передельные знанения 


\begin{tabular}{|c|c|}
\hline \multicolumn{2}{|c|}{ Aprll 6. 1895} \\
\hline alignment & roctupoaka \\
\hline alpha particles & альфа частицы \\
\hline $\begin{array}{l}\text { Amerlcan Nuclear Society } \\
\text { Nits }\end{array}$ & Американское адерное обцество \\
\hline americlum & вмериций \\
\hline amplifler & усилитөль \\
\hline analog-to-digital converter & $\begin{array}{l}\text { аналогово - цифровой } \\
\text { перөобразователь }\end{array}$ \\
\hline \multicolumn{2}{|l|}{$A D C$} \\
\hline anahysis, chemical & анализ, химичөзкий \\
\hline analyzer & анализатор \\
\hline annual throughput & годовая произвидительность \\
\hline anomaly & аномелия \\
\hline ANS & Американское ядерное общество \\
\hline \multicolumn{2}{|l|}{ Amerlaen Nuclear Soclety } \\
\hline apparatus & прибор \\
\hline $\begin{array}{l}\text { An inotrument / apparatus for qulek determination } \\
\text { of material typo in field conditions. }\end{array}$ & 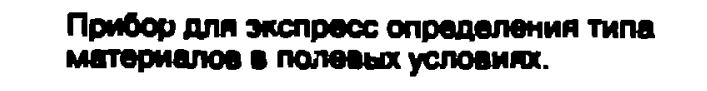 \\
\hline apparent loss & очевидная потеря \\
\hline arithmetic correctness & арифмөтическая правильность \\
\hline armature & тpy6a \\
\hline armored blanket & зацитное покрытия \\
\hline Arms Control \& Dlsarmament Agency & $\begin{array}{l}\text { Aгенство по контрслю над } \\
\text { вооружөниям и резоружением } \\
\text { (AКВР) }\end{array}$ \\
\hline ACDA & AKBP \\
\hline assay & анализ \\
\hline & колинественнй \\
\hline assay, Isotopic & анализ, изотопный \\
\hline
\end{tabular}




\section{Mces A conoral Glowary \\ Los Alamos Mational Leboration - Transiation end Interprotution 8ervico \\ April 6, 1905}

\section{background region of interest}

A background region of lnserent must be ent cbow the axiey pack to subtred the continume under the peak.

bedge

bar-codes

barcode

baich

batch data

beginning inventory

B

BFS

a fuli-seale model of a working rastor whthout the cooling loop for conducting rewarch and Imitating reector proceseces and emergencles (BFS-1, BFS-2 at Otoninak, IPPE)

\section{BFS}

a full-acale model of a working reactor without the cooling loop for conducting resaarch and imitating reactor processes and amergencles (BFS-1, BFS-2 at Obninak, IPPE)

BI

beginning inventory

blas

bllateral co-operation agreement

boat
Фоновая рассматривеемея область

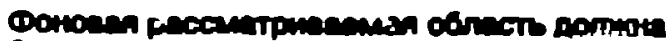

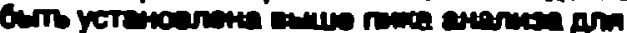

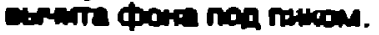

пporyyck

uтрих-коды

Uтрихоеой кOA

cap ina

6ар код

uтperoses icon

партия

данные партии

пөрвичная инвөнтаризация

6DC

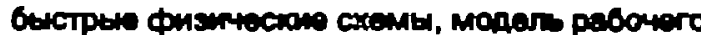

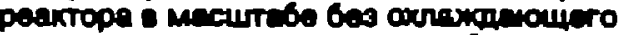
контуре a

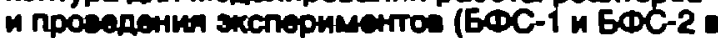

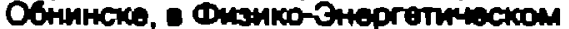
Институть)

\section{быстрыө физичөские схөмы}

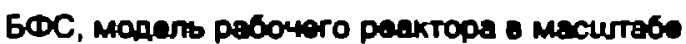

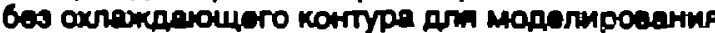

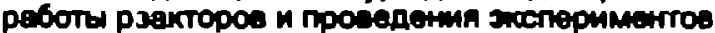
(EOC-1 и BDC-2 : OGthitrere, :

Фианко-Знергетниеском Институто)

первичная инвентаризация

\section{Смөщениө}

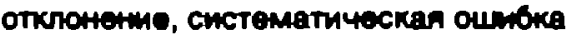

систөматичөская ошибка

смецения, отилонение,

дөустороннөө соглвшөниө о сотрудничөстве

крьсталлизатор 


\begin{tabular}{|c|c|}
\hline \multicolumn{2}{|c|}{ April 61995} \\
\hline bolling water reactor & реактор на кипнией воде \\
\hline book inventory & $\begin{array}{l}\text { материальный бaланс по } \\
\text { документам }\end{array}$ \\
\hline \multicolumn{2}{|l|}{ of a matarial balance area } \\
\hline book inventory & инвентаризационная опись \\
\hline book inventory of a material balance & $\begin{array}{l}\text { зарегистрированное } \\
\text { инвентарное количество }\end{array}$ \\
\hline book-physical inventory difference & $\begin{array}{l}\text { расхождение по документам между } \\
\text { учөтным количеством и Фактически - } \\
\text { наличиным количөством я.М. }\end{array}$ \\
\hline \multicolumn{2}{|l|}{ BPID } \\
\hline boron & 6op \\
\hline bcron-loaded polyethylene & нвсыщценный бором полизтилен \\
\hline BPID & $\begin{array}{l}\text { расхождение по документам между } \\
\text { учетным количеством и фактически - } \\
\text { чаличиным количөством я.М. }\end{array}$ \\
\hline \multicolumn{2}{|l|}{ book-physical inventory differencs } \\
\hline breakdown & пробой \\
\hline bridge-router & мост-маршрутизатор \\
\hline $\begin{array}{l}\text { Bridge/Router directs the data into the network } \\
\text { segments. The resuh is a higner pertormance } \\
\text { notwork. }\end{array}$ & 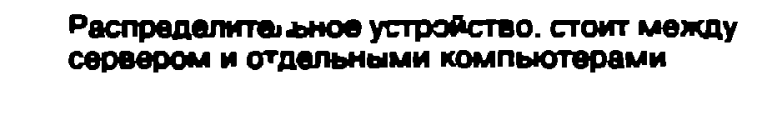 \\
\hline bulk handling facilities & $\begin{array}{l}\text { установки с матөрчалами в } \\
\text { балк-формө }\end{array}$ \\
\hline bulk materıals & матөриалы в балк форме \\
\hline C/S device & $\begin{array}{l}\text { устройство для сохрания и } \\
\text { наблюдөния }\end{array}$ \\
\hline \multicolumn{2}{|l|}{ containmentsurveillance } \\
\hline C/S measures & $\begin{array}{l}\text { мөры по обөспечөнию сохранимости } \\
\text { и наблюдөнию }\end{array}$ \\
\hline \multicolumn{2}{|l|}{ containmentrurveillance } \\
\hline cadmium & кадмий \\
\hline calculate & вычислять \\
\hline calıbration & калибровка \\
\hline calıbration curve & калибровочная кривая \\
\hline
\end{tabular}




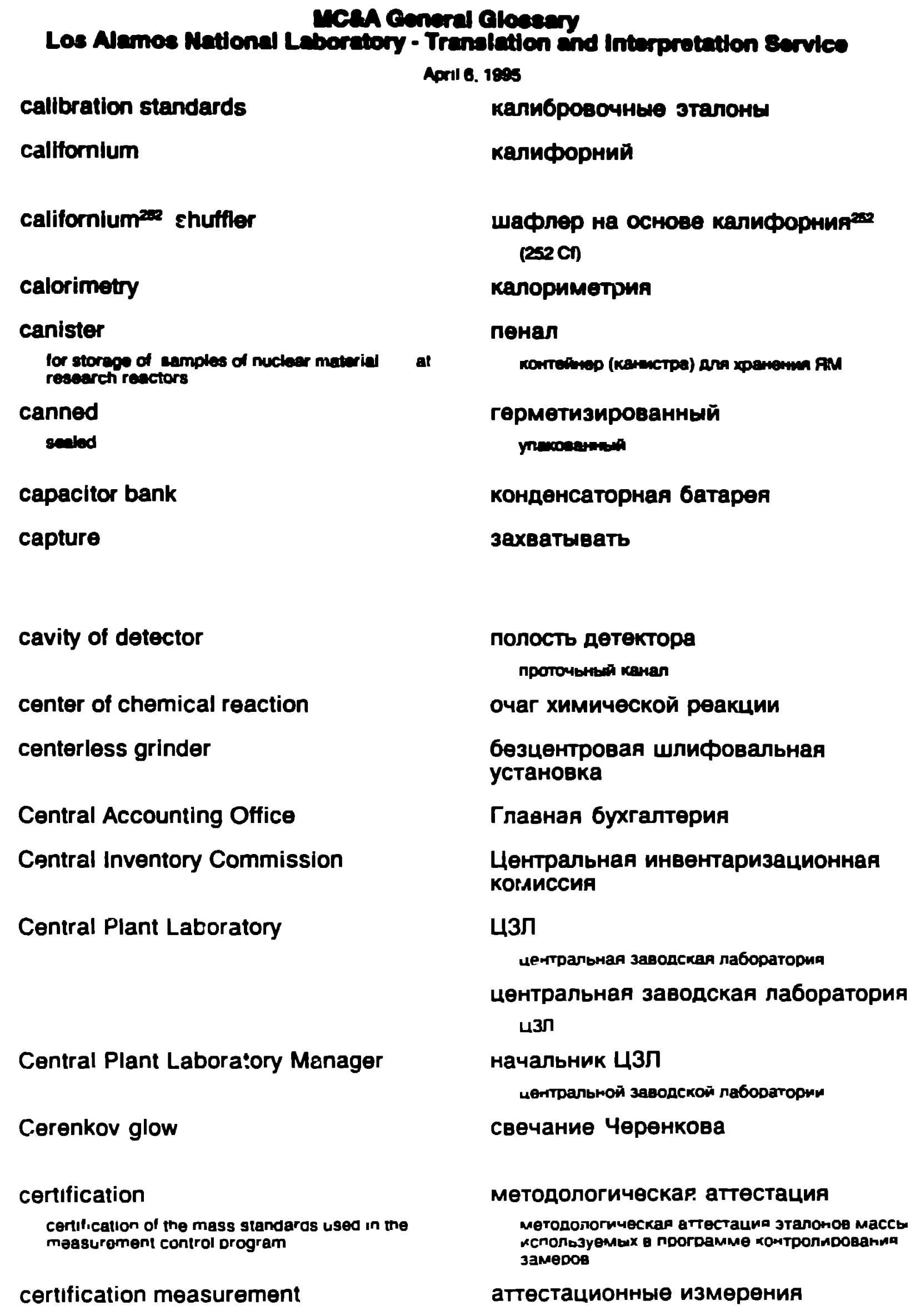




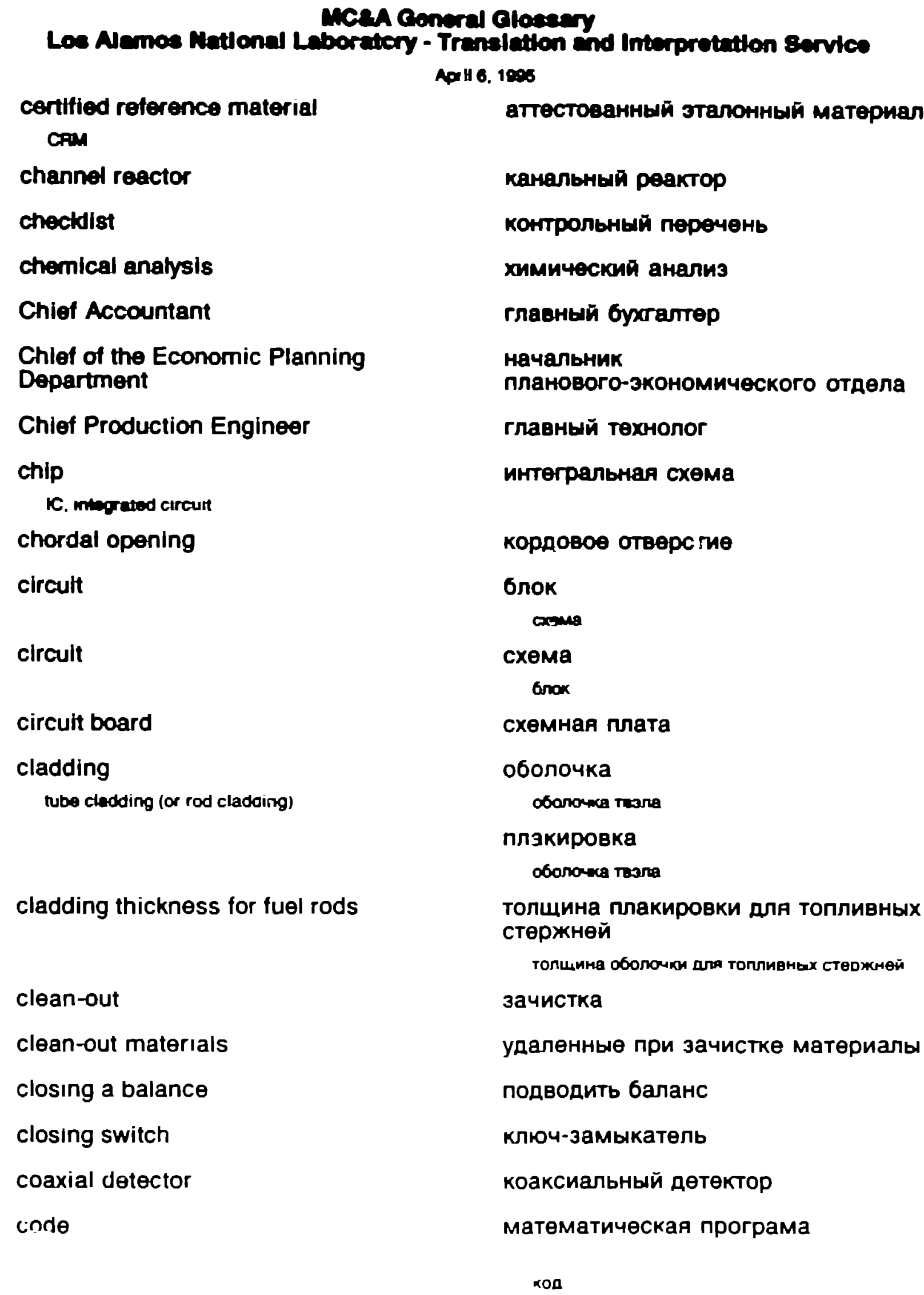




\begin{tabular}{|c|c|}
\hline \multicolumn{2}{|c|}{ April 6. 1895} \\
\hline $\operatorname{code}$ & код \\
\hline \multicolumn{2}{|r|}{ vertensmmeccos noorpene } \\
\hline coil & BurToK \\
\hline coincidence essay & анвлиз совпадений \\
\hline colncidencrs counter & счөтчик совпадөний \\
\hline cold spots & холоднь' участки сколЛения \\
\hline 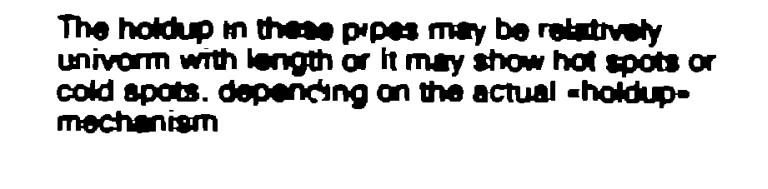 & 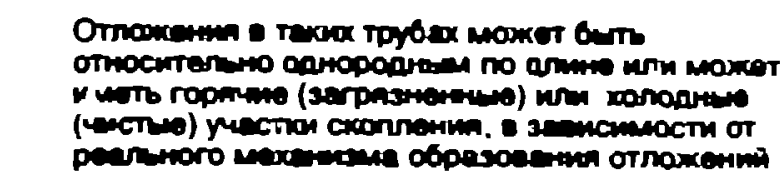 \\
\hline compact toroid & компактный торойд \\
\hline computer interface & компьютөрный интөрфөйс \\
\hline computer software/hardware & программно-аппаратное оснащөниө \\
\hline $\begin{array}{l}\text { Dowolopment of Genoral Computer } \\
\text { Soltwer thardware Requirements for the MCSA } \\
\text { System }\end{array}$ & 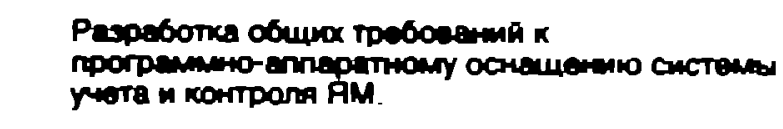 \\
\hline confldence & достовөрность \\
\hline Statistical & - стөтмстике \\
\hline confidence interval & довөритөльный интөрвал \\
\hline confidence level & довөритөльһ山й уровөнь \\
\hline confıderıce limits & доверительныө прөдөлы \\
\hline confirmatory measurement & подтвөржающия измерения \\
\hline ccnservation of the magnetıc flux & сохранөниө магнитного потока \\
\hline consistency & согласованность \\
\hline containment & сохранөние \\
\hline \multicolumn{2}{|l|}{ IAEA Grossary Term - 248} \\
\hline contaınment/surveıllance device & $\begin{array}{l}\text { устройство для сохрания и } \\
\text { наблюдөния }\end{array}$ \\
\hline \multicolumn{2}{|l|}{ C/S device } \\
\hline containment/surveıllance measures & $\begin{array}{l}\text { меры по обөспечөнию сохранимости } \\
\text { и наблюдөнию }\end{array}$ \\
\hline \multicolumn{2}{|l|}{ C/S measures } \\
\hline control & контроль \\
\hline $\begin{array}{l}\text { EJuipment - Dased control Systems for items } \\
\text { containing nuclear maierial } \\
\text { Othen used for monitoring assay or measurement }\end{array}$ & 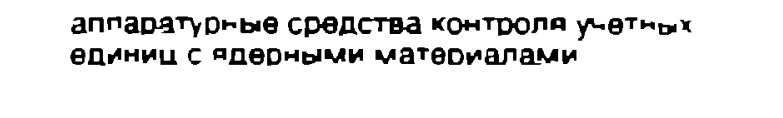 \\
\hline
\end{tabular}


Los Aamos Mational Laboratiory - Translation and Imterprotation Sorvice Auril 6. 1996

control limits

Control Methodology Section

Control Methodology Section

controlled access point

controlled potential coulometry

conversion plant $\mathrm{U}_{3} \mathrm{O}_{8}-\mathrm{UF}_{6}$

correction factor

correlation

count

count rate

ratio

counter

counter, active well coincidence

AWCC

counter, colncidence

counter. gas proportional

counter, Geiger-Muller

GM counter

counter, high-level neutron coincidence

HLNCC

counter. Inventory sample

counter. multiplıcity

counter, neutron colncidence контрольные уровни

контрольно методическая группе arr

KMГ

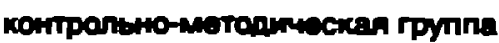

кпнтрольно-пропускной пункт Kחп

$\mathrm{K} \Pi$

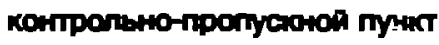

кулонөметрия с управляемым потенциалом

завод по переработкө $\mathrm{U}_{3} \mathrm{O}_{8}$ в UF.

поправочный фактор

соотношение

считать

peructpwpoedtb

регистрировать

считать

скорость счета

счөтчик

счөтчик совпадөний, активный колодөзный

счөтчик совпадөний

счөтчик, газовый пропорциальный

счөтчик Гөйгера-Мюллера

счетчик нөйтронных совпадөний. высокопоточный

счөтчик для инвөтаризацонных 06сазцов

СчетчИк множөствөнностөй

счөтчик нөйтронных соөпадөний 


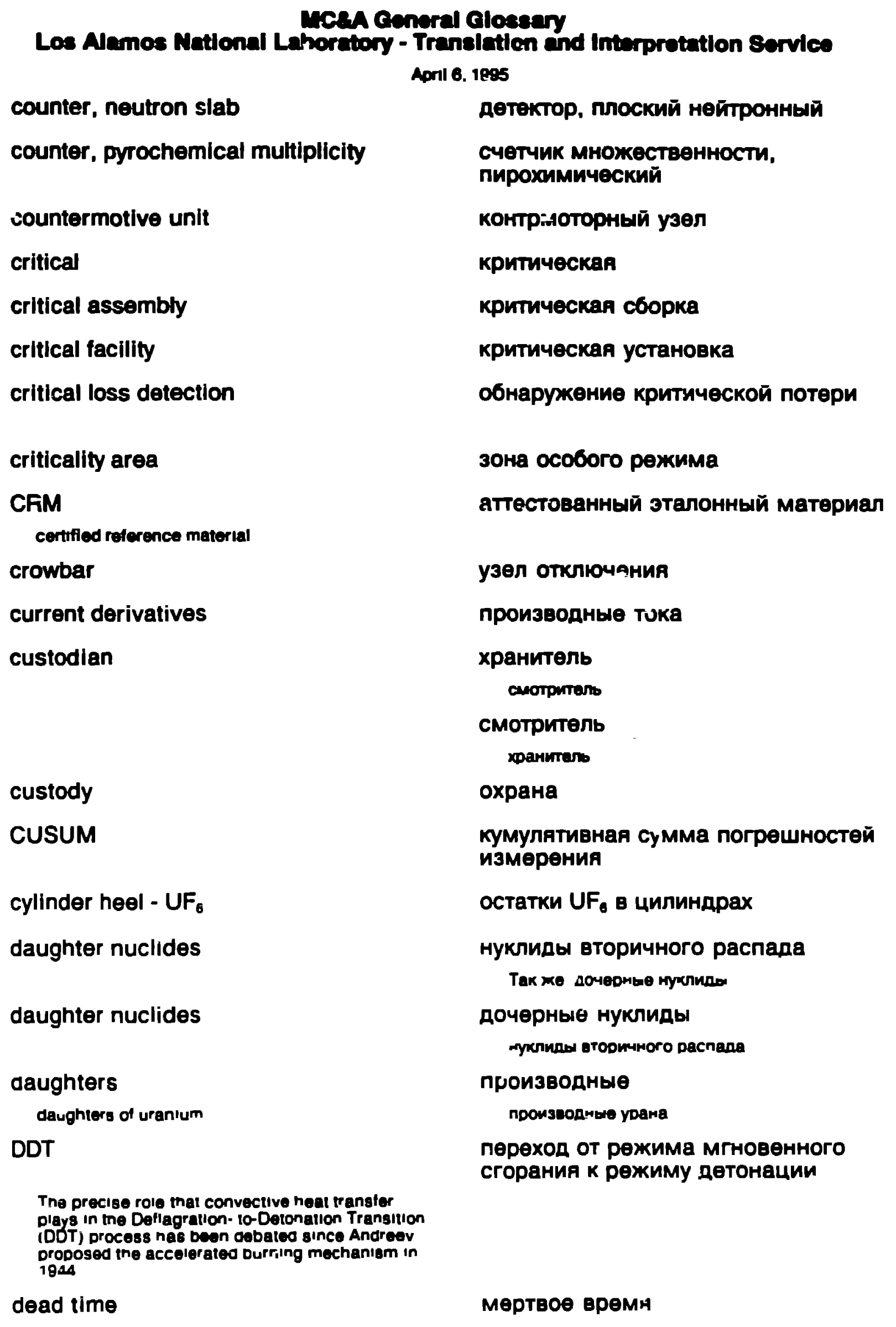




\section{Los Aamos Natlonal Laboratory - Translation end Intorprotation Sorvice}

April 6. 1995

decay

default

defense in depth

Jegassing

degradation

degredation to other materials

delay

delayed neutrons

dolayed neutrons emitted by fission fragments

dense materlals

densitometer

density

department manager

depleted uranlum

depletion

Deputy General Director for Production

Deputy General Director for Quality Control

derived estimate

design pacran

Умолчвниө

эшөлонированная оборона

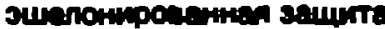

обезгаживаниө

дөградация

деградация в друтие материаты

задержка

запаздывающие нейтроны

запаздывающие нейтроны, испусквөмыө осколками дөлөния

плотные матөривлы

денситометр

плотность

начальник отде::өния

Обөднөнный уран

обеднение

заместитель генерального директора по производству (ПТО)

заместитель генерального директора по качөству (OTK)

полученная оценка

Degegmman

вывөднная оценкв

потунанмая

конструкция

7poent npoermmdosarke

проектирование

проект консторани 


\begin{tabular}{|c|c|}
\hline \multicolumn{2}{|c|}{ April 6. 1006} \\
\hline \multirow[t]{2}{*}{ design information } & $\begin{array}{l}\text { информация о конструкции } \\
\text { проемтая мнормаиия }\end{array}$ \\
\hline & 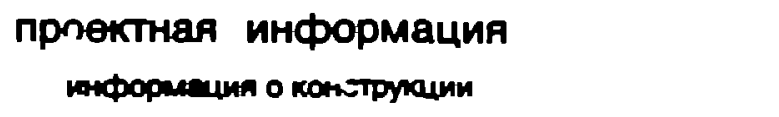 \\
\hline design of the safeguards approach & $\begin{array}{l}\text { разрвботка подхода к применению } \\
\text { гарантий }\end{array}$ \\
\hline detection & обнаружение \\
\hline detection probability & вөроятность обнаружөния \\
\hline detection time & время обнаружөния \\
\hline detector & дөтөктор \\
\hline \multirow[t]{3}{*}{ detector cavity } & полость дөтөкторе \\
\hline & протоньныа канал детектора \\
\hline & $\begin{array}{l}\text { проточьный канал дөтөктора } \\
\text { полость дөтектора }\end{array}$ \\
\hline de.errence & сдөрживаниө \\
\hline deuterium & дөйтөрий \\
\hline device & устройство \\
\hline dle-away time & өрөмя ослабления \\
\hline difflcult-to-measure scrap & трудноизмөряөмый скрап \\
\hline direct use materlal & матөривл прямого использования \\
\hline discard & 6өзөозвратная потөря \\
\hline discharge cleaning & разрядная очистка \\
\hline discrepancy & расхождөниө \\
\hline discriminator & дискриминатор \\
\hline disks & блочки \\
\hline research pollets & Даския төблетки \\
\hline distribution & распрөдөлөниө \\
\hline \multirow[t]{2}{*}{ diversion } & пөрөключөниө \\
\hline & 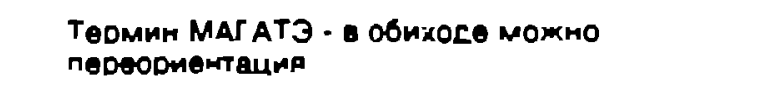 \\
\hline diversion path & путь переключемня \\
\hline
\end{tabular}


Los Alemos Natlonal Leborationy - Translation and Interpretation Servlce

April 6. 1905

documentation

documents

DOE field offlce

also- DOE operationa office

DOE operations office

abo. DOE freld ofilice

dosage

double-entry bookkeeping

drums (55 gallon)

dual interrogator

dummy load

effective kilogram

$\mathbf{e g}$

effective mass

ekg

eHectlve kllogram

element factor (uranlum)

the meagured weights are converted by the comouter besed syotom to weights of uranium eiement by apolying a specific element factor Desed on fne uranium aceay of the liem nr lot or by sunolying a uranium-olement fertor

ending Inventory

energy

energy efficlency

engineering scele experiment документация

документы

рөгиональный отдел Министөрства знергетики США

рөгиональный отдел Министөрства знергетики США

Мощность дозы

бухгеттерия двойного учета

200-литровые метеллические бочки

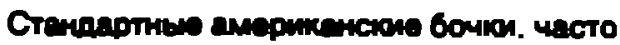

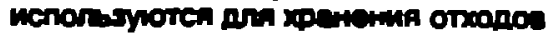

двойной облучатель

эквивалент нагрузки

зффективный килограмм

sष $\boldsymbol{\Phi}$

зфффективная месса

зффективный килограмм

зффектионың килограмм

урановый козффициент

.. компьотермan crotema nepsesogrt

измеренның вес в еec урама (ecex nзoтonos

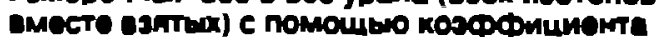

оснозанного на анализе учетно

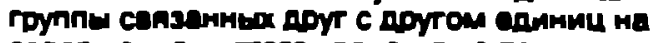

conepmanne metoro ypare uni c nomourso

козффициетт урана

Окончательное инвентарное

количөство

энергия

знергозффективность

экспегимент на инженерном уровне 


\section{MCe.A Genoral Gloesery}

\section{Los Alamos National Laboratory - Translation and Interpretation Service}

April 61805

enriched material

enriched uranium

enrichment

enrichment blending

enrichment meter

enrichment plant

isotode separation plant

enterprise

To distinguish it from FACILITY in the IAEA maaning of the term

equipment

equipment holdup

error

error propagation

error- type I error

error - type II error

\section{ESARDA}

European Sateguaras Researcn ana Development Aseociation

escapıng gamma rays

estimate

European Safeguards Research and Develooment Assoclation обогащенный матөриал

обогащөнный уран

обогащение

Смөшиваниө матөриала с различной стөпенью обогащения

измөритель обогащения

завод по обогащению

sasan no pasneленим изотопое

предприятие

DЛन того, чTO6) отлимМть От УСТАНОВКИ опредалении МАТАТЗ

оборудование

матөриал, остающийся в төхническом оборудовании

ошибка

опрөдөлөние рөзультирующей ошиєки

ошибке первого рода

ошибка второго рода

Еөропөйская Ассоцивция Исслөдоватөльских и Oпытно-Конструкторских Работ по Гарантиям безопасности

гаммв-пучи, уходащие из контөйнөра оцөнивать

Ougrix

Европөйская Ассоциация Исслөдовательских и Опытно-Конструкторских Работ по Гарантиям безопасности

Оценка (количествөнная)

evaluation 


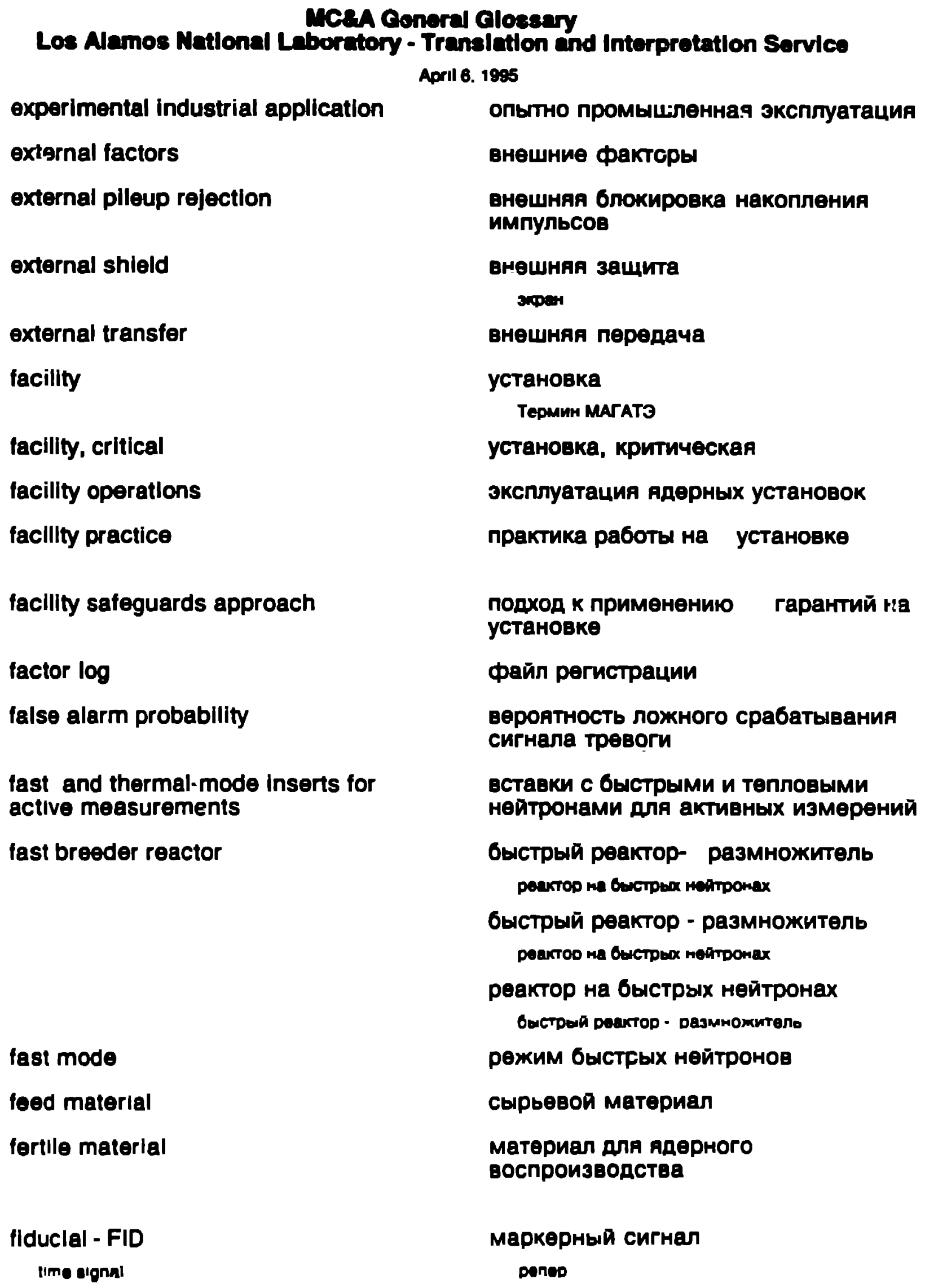




\section{MCeA Goneral Glossary
Los Alamos Natlonal Laboratory - Translation and Interprotation Sorvico}

Aoril 6. 1995

fifty-five gallon (200-liter) drums

\author{
financial accounting \\ fingerprint \\ fissile material \\ IAEA usege - LAEA Glogeary Term $\% 33$ - apucial \\ fissionable material . LANL usage - Isssile material \\ FM \\ fisslie materials
}

FM: fissils materials in AT-400A containers enter the fecilin from the manufecturing plamts uranium Ü-235 and plutonıum

fission

fission fragments

fission rate

fissionable material

IAEA uage - IAEA Gipssary Term $\$ 33$ - special fissionable materıal - LANL usage - fissile materia FM

fissloning isotope

flare

Flat-Squared Counter

flow key measurement point

fluid-fluid phase segregation

Eaullibrlum enemical composition ana possibie fluld-fluld onase segregarions can have an inflience in the total EUS of th-se mixtures

FM

$$
\text { frasile material }
$$

fraction

free path 200-литровые мөталличөские 6очки

Crannaptute amepnanacion 60410. 4acto

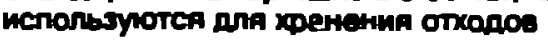

бухгалтерский Финансовый учет

дактилоскопический отпөчаток

дөлящийся материал

aM

дөлящиеся матөриалы

ДМ: депиииеся материялы в комтейерех типе AT-400A noctynanior a xpanvinue C npos3aoncteeHrbx kon6mmatos уран U-235 и птутомий

деление

осколки дөлений

интөнсивность дөлөний

дөлящийся матөриал

aM

дөлящийこค изотоп

вспышка

счөтчик с постоянной

эФфөктивностью при разных положениях и энергияХ нөйтронов

клкчевая точка для измөрения потока материяла

раздөлениө газовожидкостны)! Фаз

ДM

депащиеса материалы

доля

сөободный пробөг 


\section{MCeA Genoral Glossary \\ Los Alamos National Laboratory - Translation and Intorpretation Sorvico}

April 6. 1995

tuel assembly

an cxempla of a product shiprnem

fuel bundle counter

rul ascumbly counter

fuel cell

fuel element

fuel fabrication plant

fuel plate

fuel rod

or subanianbly

fuel rooto tial make up a huel masembly sonetimus referreo to as a luel eloment

full width at half maximum

FWHM - Record the full width at half maximum and half woth of the radial response at this distance

FWHM

Iull width at haif maximum - Record the full wioth at half maximum and half woth of the radisi response at this disiance

gain

gamma

gamma scanning

gamma spectrometry

gamma-ray attenuation and absorption corrections

gas mass spectrometry

gas proportional counter топливная сборка

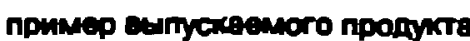

счетчик длА roпливных с6орок

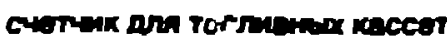

топлирная батарея

топливый элемент

завод по изготовлению топлива

топлив.taя пластина

топливный стөржөнь

whin nancoopres

топливная подсборка

whis ctepmerts

ТВЭЛ (төплэвыдөлคющий элөмөнт)

Tean

төпловыдөляющий элөмент т837

полная ширина на половине максимума

Зерегистрируіте полнуо ширину на половине максимумма радиального отллика на зтом Dacctonima

полная ширина на половине максимумв

Зарегистриоуйте полную ширину на польеине максимума радюального откиика на зтом Deccronmun

усиление

гамма

гамма-сканирование

гамма-спектрометрия

поправки на ослабление

гаммз-излучөния и на поглощөние

газовая масс-спөктромөтрия

газовый пропорцивльный счөтчик 


\section{MCeA General Gloseary \\ Los Alamos Natlonal Leboratory - Translation and Interprotation Service}

April 6. 1895

gate

Geiger-Muller counter

GM counter

general account

General Director

generalized-geometry

glove box

glove-box line

GM counter

Geiger-Muller counter

go off scale

goal quantitles

graded

graded response

granular explosives

In an effort to quantify the permeability of granular beds. Shepherd and Begeal performea both quasistatic (glass Deads and three granular exolosives CP. HMX. and HNS!

graphite

gravimetric analysis

green pellet

green $\mathrm{UO}_{2}$

grinder

grınder water

gross welght

half-life

hastalloy-C

heavy water ворота (или имтульс оттирания и загіирания)

счөтчик Гөйгөра-Мюллөра

งீщий счет

Гөнерапьный директор

произвольная гөомөтрия

перчаточный бокс

линия пОрчаточных 6оксов

счөтчик Гөйгөра-Мюллөра

зашкаливать

цөлөвыө количөства

Mr10гоуровнөвذй

Mroroyposmble ornetmbie Medt

взрывчатое ьөщөство в видө гренул

графитт

гравимөтричөский анализ

нөспөчөнная таблетка

неспөчөнный диоксид урана

шлифовальная установка

вода из-под шлиФовки

масса 6рутто

пөриод полураспада

гасталлой-С

тяжөлая вэда 


\section{Los Aamos National Laboratory - Translation and Interprotation sorvice}

April 6. 1905

\section{heavy water reactor \\ HWA \\ heol \\ UFB cytinder how \\ heel, cylinder - UF. \\ hellcal generator \\ hermetically sealed}

nermeicicaly sealed container

HEU

highly orriched uranium

high resolution gamma ray

spectrometry

HAGRS

high temperature gas cooled reactor

HTGR

high-energy neutrons

high-level neutron colncidənce counter HLNC

HLNCC

highly enriched uranium

HE'J

HLNCC

nigh-level neutron coincidence counter

hold-up inventory

all of the hold-up Inventory can de measureo

holdup

hot spots

The hordup in these pipes may be relativery univorm with length or It may show hot spots or cold spols depending on the actual -holdup: mechanism

\section{HRGRS}

тАжеловодный реактор

остатки

octation UFE - uviminpex

остатки UF。 в цилиндрах

спирагьный генератор

капсулированный

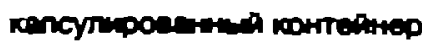

BOY

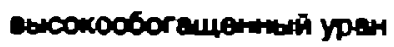

гамма-спектрометрия высокого разрешенния

высокотөмпературный

газоохлаждаөмый реактор

нөйтроны высокой энөргии

нөйтронный гчөтчик совпадөний с высокой скоростью счөла

высокообогащөнный уран

BOY

нөйтронный счөтчик совпадөний с өысокой скоростью счөта

матөриал, остающийся в установкө

весь матөрнал. остаюеий̈сп в устаноеках момет бOTт мзмөрен.

матөриал. остающийся в установкө

TEDNum MAГATЭ

горячие участки скоплөния

Oтпожения \& такмх трубех может быть

относительно однородным по длине или момет

мметь ГОоРине (загрлзненные) или холоднын

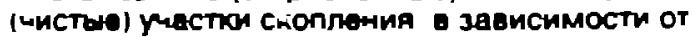

реального механизма образования отпомений.

гамма-спөктрометрия высокого

разрөшөнния

nigh resolulion gamma ray sDoctrometry 


\section{mcen Genoral Gloasary \\ Los Alemos Nattonal Leboratory - Translation end Interprotation Eervico}

April 6. 1905

\section{HTGR}

high temperature ges cooled renctor

hub

computer network

HWR

havy witer reactor

mybrid

\section{IAEA}

The containers are tested in eccordence with LAEA requirements for etrength against the external factors that are typical of sericus transportation accidents.

IAEA

International Atomic Energy Agency

IAEA detection goals

IAEA Safeguards information System

ICA

The item controt erea (ICA) structure is des gned to provide maxamum imventory and administrative control over all materials not in an immediata processing gtatus and over all items emenabte to Item control

ICR

inventory change reoort

ID

Inventory alfference

Immunity

Import and export

Improved nuclear material

impurities

in-cabinet shuffler

\section{высокотемпературный газоохлаждаемый реактор}

центральная станция

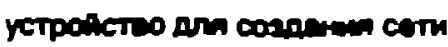

ТАЖөлОводнЫЙ рөактор

\section{MАГАTЭ}

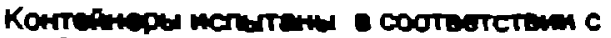

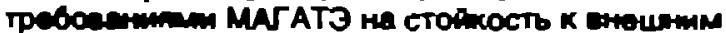

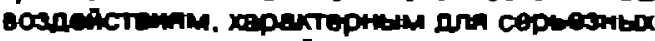
тparconoptwox asepun.

MATAT3

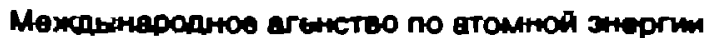
цели обнаружения МАТАТЭ

систөме информации МАГАТЭ по гарантиям

зона контропя учөтных өдиниц

Струттра зоны контрапя учетных единиц сделана так, чтобы оbecreukть

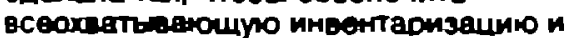
максимальный впмннистретиеный комтроль man всеми метерналами не находлицимст в переработке в нас.0ящеө врема. м надо всемн уеттыми өдиницами подлежацими контоол-о

Отчет 06 изменениях инвөнтарных копичөств материала

расхождение в инвен- талном количествө материала

устойчивость

импорт и экспорт

улучшөнный ядерный матөриал

примөси

внутрикамөрный шафлөр 


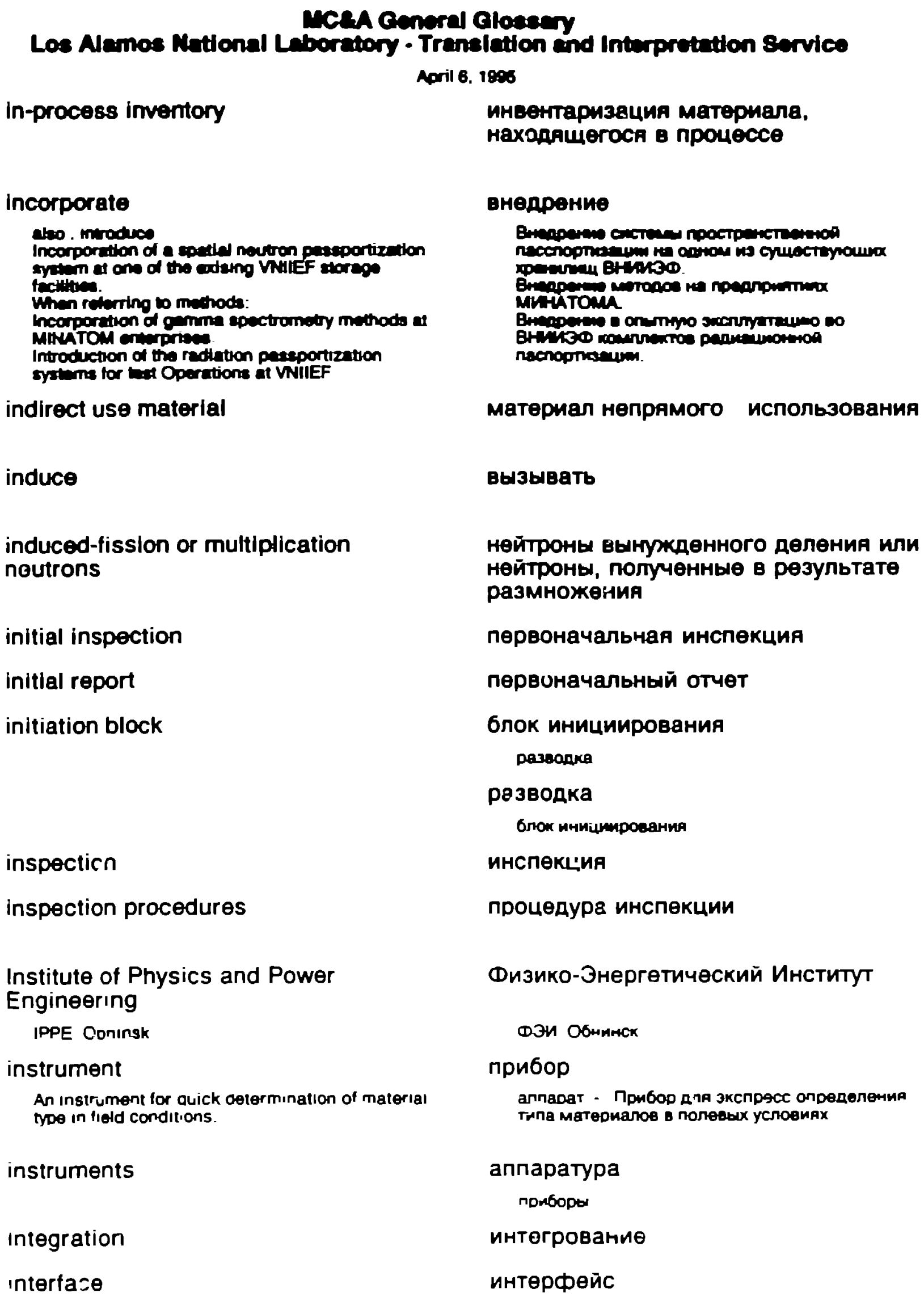




\section{Los Alemos National Leboratory - Tranalation end Imterprotation service}

Aprl 6. 1900

Interlab steering group

intermediate product

internal control system

internal review

internal transfer

International Atomic Energy Agency

WEA

international fuel cycle management

international plutonium storage

IPS

International Science and Technology Center

ISTC

Interrelational

inventory
Можлабораторная координационная rpynna

промежуточный прогукт

система внутреннего контроля

Внутренняя проверка

өнутренная передачя

Междь чародное агенство по атомной энөргии

MarAT3

международноө управление топливным циклом

мөждународноө хранөниө плутония

nod

Мөждународный Научно-Төхничөский Цөнтр

MHTL

взаимозависимое

матөриально-производстөөнный эanac

Rare usego

количөство наличного матөриала

инеантарное количестро материела - o6е

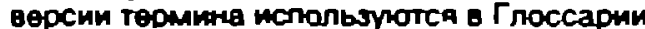
MATAT3

инвентарь

Инвөнтарное количөство матсриала

количөстео наличного матөриала - obe вөрСии төрмине мспользуются в ГЛоссарии МАГАТЭ

ОТЧөт О6 изменөнияХ инөөнтарных количөств матөриала

провөрка измөнөния инвөнтарного количөства (матөриала)

координалор инвөнтаризации

Inventory coordinator 


\begin{tabular}{|c|c|}
\hline \multicolumn{2}{|c|}{ April 6. 1995} \\
\hline inventory cut-off & $\begin{array}{l}\text { остановка для провөдөния } \\
\text { инвөнтаричации }\end{array}$ \\
\hline inventory difference & $\begin{array}{l}\text { расхождөние в инвөн- тарном } \\
\text { количөстве материала }\end{array}$ \\
\hline \multicolumn{2}{|l|}{ ID } \\
\hline & инвөнтарная разность \\
\hline inventory item & инвөнтарная учөтная өдиница \\
\hline inventory key measurement point & ключевая точка измөрения \\
\hline KMPP & кти \\
\hline inventory KMP & ключөвая точка измөрөния \\
\hline \multicolumn{2}{|l|}{ kej, maasurement point } \\
\hline inventory location & инвөнтарная зона \\
\hline inventory outside the plan & внөплановая инвөнтаризация \\
\hline $\begin{array}{l}\text { An inventory outside the plan conducted to check If } \\
\text { the phyeical inventory c! nuclear materials } \\
\text { matches the accounting inventory emounts }\end{array}$ & 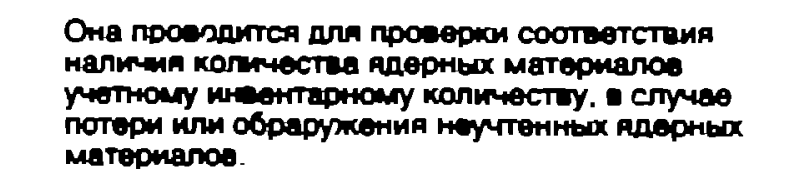 \\
\hline inventory package & инвөнтаризационный пакөт \\
\hline $\begin{array}{l}\text { contains a set of inventory stickers and a set of } \\
\text { pmysical inventory shoets }\end{array}$ & $\begin{array}{l}\text { сопержит небор инвентарннох этикөток и набор } \\
\text { лигтов описей Физннеской инвентаризации }\end{array}$ \\
\hline inventory reconciliation & $\begin{array}{l}\text { сопоставлөниө зарөгистрированного } \\
\text { и фактичөски наличного количөства }\end{array}$ \\
\hline inventory sample counter & счөтчик инвөтаризацонных образцов \\
\hline inventory team & ннвентаризационная команда \\
\hline & $\begin{array}{l}\text { провөрка инвөнтарного количөст а } \\
\text { матөриала }\end{array}$ \\
\hline IPPE & ФЭИ \\
\hline $\begin{array}{l}\text { Instliute of Physics and Power Engineering } \\
\text { Obninsk }\end{array}$ & Фмзико-Эмеогетический Ипститут ОВнинек \\
\hline IPS & MXП \\
\hline international Dluionium storage & мөжсдународное хоанемне плутомиа \\
\hline irradiated material & облучөнный матөриап \\
\hline ISotope factor & изотопный коэФфициент \\
\hline
\end{tabular}




\section{Mcen General Glossary \\ Los Alamos National Laboratory - Transiation and Interpretotion service}

April 6. 1995

Isotopes

isotopic assay

isotopic dilution mass spectrometry

isotopic source

isotopics

ISTC

International Science ano Technology Center

item

In IEA or MC\&A inventory torms

item

When ueed for NDA \& other measurements

item

Instrument - bessd monitoring systems for ibms containing nuclear materials Russian literally mans ITEM OF ACCOUNT

Item

maasured Item

Item control area

ICA. The item contro area structi-e 18 designed to provice maximum inventory and administrative control over all materials not in an immediate proceseing status and over all items amenabte to fiem control

Item counting

Item facility

Item Identification

junctlon box

$K$ - or $L$ - edge densitometer изотопы

изотопный анализ

масс-спектрометрия С изотопным разбавлением

изотопный источник

изотопный состав

MHTЦ

Междунарсдный Науню-Техническй Центр

учөтная өдиница

В опмках МАГАТЭ или инвентаризации ฉЛя

CYnK

объөкт подлөжащий анализу

\section{учөтная өдиница}

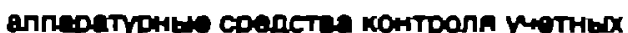
equгтиц с паеонымем матерналами

о6разөц

когда речь идет о перазоушаюиек анализе o6peseц вл МАГАТЭ и инвентаризации пробв

зона контроля учөтных өдиниц

Стоуктра зоны контрола унетных өдинии спелана так. что6ы обеспенить

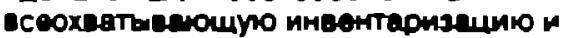

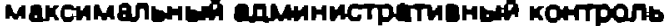
man есеми матернагами. не неходлщимися в

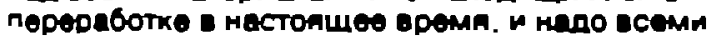
ретнымн өдиницами подлежацима контроЛю

подсчөт учөтных өдиниц

установка с ядөрным матөриалом в виде прөдмөтов

идөнтиФикация учөтных өдиниц

распрөдөлитөльная коробка

дөнситометр с исплоьзованием зФфекта K - или L полосы погпощения 


\section{MCen Genoral Gloseary \\ Los Alamos National Laboratory - Translation and Interpretation Eorvice}

Aprll 6, 1995

key measurement point

KMP - locetions where nucher materlal appears in auch a form thet it my be meacured to dowermine meterty fiow or imventiony

KMP

ky mosurement point - locations where muclang materlal appears in such a form that it my be moasured to determine matc rial frow or Inventory

\section{lagoon}

For the model plant, llquid westes tranderred to the coive evaporation legoone are mensured by the volumo end concentration of ench batch volum. transturred.

leached hulls

\section{LEMUF}

limit error of material unecoounted for - in the U.S., the iraid tor a certain minimum measureme it qualty is spectiled by nimerical values for the limit of error of MUF (LEMU:F)

\section{LEIJ}

low enriched uranium

LEU fuel fabrication facllity

low-enriched uranium fuel fabrication facillty

liberation of energy

light water cooled, graphlte moderated reactor

LWGR

light water reactor

LV.R

limit error of material unaccounted for

LEMUF - In the U.S. the need for a certain mini.num measurement qually is specified by nimerical values for the limit of error of MUF (LEMUF)

IImlts of error

\author{
ключевая точка измерения
}

КТИ - места, где пдернй метериел

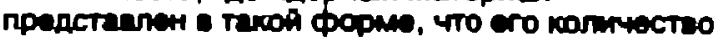

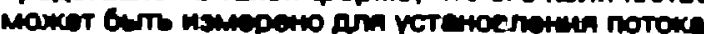
matepvank . .

KTV

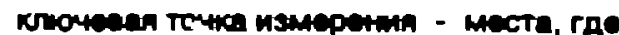

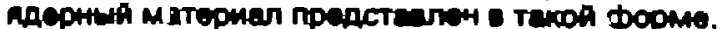

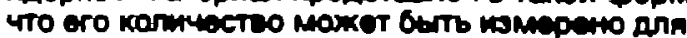

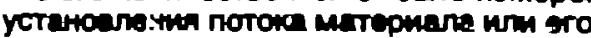

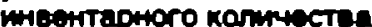

\section{отстойный бассөйн}

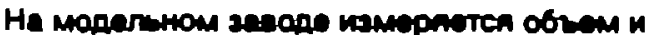

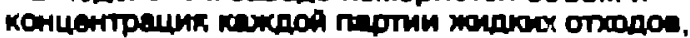

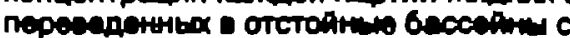

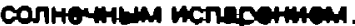

\section{выщелоченные отходы в виде шелухи}

\section{ПОКHM}

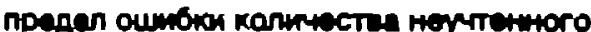

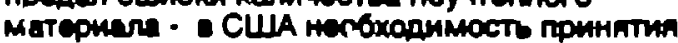

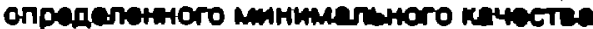
измерений определени числониними

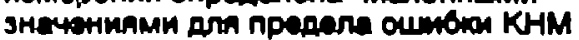
(ПОКHM)

\section{HOY}

низко0богеценінй уран

предприятие по производству низкообогащенного уранового топлиอа

\section{выделение знөргии}

рөактор большой мощностиб уранграфитный, кипящий, канального типа

PEMK

легководный ревктор

\section{предөл ошибки количестеа неучтөнного матөриала}

ПОКНМ - США Н.ООХОДМнОСТЬ ПРННАТИА определенноГО минимелІноОО качесте нзморения опредолена чнслонншми

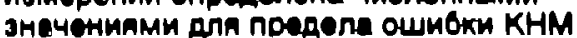
(ПОКНM)

прөдөлы ошибки 


\section{MCeA Genoral Glossary \\ Los Alamos Natlonal Leboratory - Translation and Interprotation Sorvice}

April 6. 1995

linear

long-term systematic errors

Long-term syotematic errors are eatimated from the average percent recovery observed on standerd samples

loss

lot

The date presented were obtained from a single lot of material specticaly made for the study. In this study we also have Incorporated data from other lots of material

low enriched uranium LEU

low-energy neutrons

low-enriched uranium fuel fabrication facillty

LEU tuel fabrication faclilty

\section{LWGR}

light water cooled. graphite moderated rasctor

\section{LWR}

light water reactor

MAA

material access area

majnetıc flux

Magnox reactor

main menu

manager of DOE fleld office

aiso manager of DOE operallions oHice

manager of DOE operations office

also manager of DOE fietd oHice

manganated probes

mass absorption coeficient

The mase absorption coefliclant aepende on both ine enorgy of ine gamma ray ana the material inrougn which il oasses линейный

\section{долговрөменныө систөматичөские} ошиGки

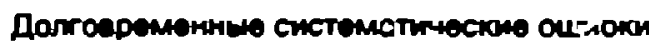

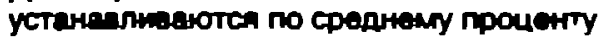

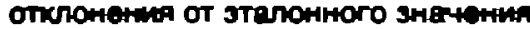

потеря

партия

низкообогащенный уран HOY

нейтроны низкой энөргии

предприятие по производству низкообогащенного уранового топлива

\section{PGMK}

раaктор 6ольшоA моцностиб урангрефитныЯ коппшия̆ канального типа

лөгководный рөактор

зона доступа к матөриалу

магнитный поток

Marноксовый рөактор

Главное меню

начальник рөгиональнего отд9ла Министөрства Энөргөтики CL'JA

начальник регионапьного отдела Министөрства знөргөтики США

\section{манганиновыө датчики}

Массовый козфФициөнт поглощения

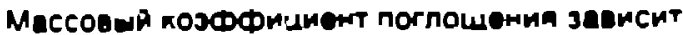

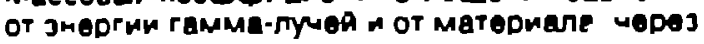
rOTODGĂ OMn npOXOAMT 
Los Alamos Natlonal Leboratory - Translation and Interprotation Service

Aprl 0, 1905

mass discrimination factor

...the spotematic error for the mases spectrometr is dertved from the calibretion date for dotermining the mase diacrimination factor...

\section{mass spectrometry}

material

In Enoligh usually asoumes nuclear materied. in Ruastan usually nuctear material or fissib mabrial is mentioned

materlal access area

MAA

material accountancy

material and equipment export guidellnes

material balance

materlal balance area

MBA

material balance component

materlal balance period

IAEA Gloseary Torm * 142 - MBP

materlal balance report

MBR

material containment

material control

Material Control and Accountability Plan

Material Control and Accounting Service Manager

material control and accounting system

MC\&A
Фактор разрөшөния различных масс

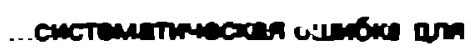

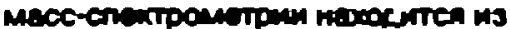

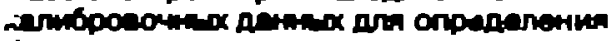

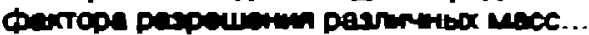

масс-спектромөтрия

материал

cax npaseuso nogonspeseavorca. ДM или AM

зона доступа к матөриалу

учет матөривлов

руководящие принципы отнгсительно экспорта матөриелов и чборудованиЯ

баланс матөриалов

зона баланса материала

35M

компонөнт баланса матөриала

период баланса матөриала

त5M

матөриально-балансовый отчөт

сохранөниө матөриала

контроль матөркалов

План учетв и контроля ядерных материал

начальник службы учөта и контропя

системв учета и контроля ядерных материвлов

CYuK 


\section{Mcen General Gloseary \\ Los Alemos Natisnal Laboratory - Transiation and Interpratation Sorvice \\ Aprll 6. 1995}

material control and accounting system; material control and accountavility

system

MC\&A

material control and eccounting system controts and monttons the movement of the flesile materials

material control area

MCA

materlal control area custodian

MCA custodian

material record card

en ench fem $x$ material is cenerated. the applicable v sight dath. material composition item identitication number. project. and nominal enrichmem are recorded on a material recora card

material survelliance

\section{material unaccounted for}

MUF - The amall quantities of material whlch are not remowed by rlgororus disan-outs are not included in the inventory. but are treated as material unsccoumed for

materials on inventory

materials testing reactor

matrix

MBA

material balance area

\section{MBP}

maieriel baiance beriod

MBR

material belance report

MC\&A system

material control and accounting eystem

MCA

malerial control area систөма учетв и контроля материалов (СУиК)

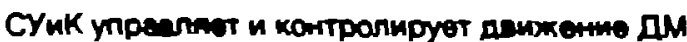
(долишиесл метериалы)

зона контроля матөриела

$30 \mathrm{M}$

ОтвөтСтвенный эоны кОнтрОЛя материала

$\mathbf{3 N M}$

карточка регистрации материала

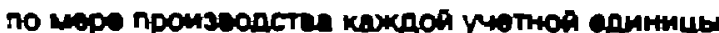
из митернала данные о массе, состасо материела ипентификеционншй номер митно

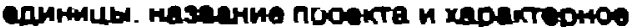

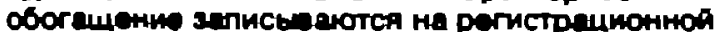
карточке метериens

нвблюдение за матөриалом

количество нөучтенного метөриала

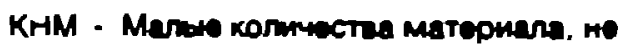

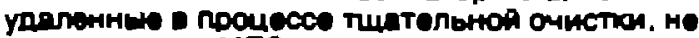
exniouarotce o MП3 ho oxniouniotce соличстьо неутенного мatepнane

матөриалы, находящиеся в наличии

рөактор для испьтания матөривлов

матрица

$35 \mathrm{M}$

30ma bonarce matepuara

ПБM

nepmon беламса мatepuena

матөриально-белансовый отчөт

Cynk

система mета и контропа пnсоншх матерналое

3KM

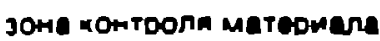




\section{Mcen Get.eral Olossary \\ Los Alamos National Laboratory - Translation and Interprotation \& srvice}

April 6. 1995

MCA

multichannel analyzer

$\mathrm{MCP}$

Measurement Control Program

Description of MCP for ecales.

mean free path

When the tank is fliled wth Raserhig rings. the mean freo path of $180-\mathrm{kOV}$ gemma raye from $235 \mathrm{U}$ is roughly $7 \mathrm{~cm}$. lar lase then the tank diameter

measured discard

measured value

measurement

messurement control

measurement control charts

measurement control program

MCP

Deacription of MCP for scales

measurement error

the enrichment meacurenent errors actually enter into the 235U LEMIF is highly dependent on proceseing and accounting booking practices

\section{measurement error}

ine enrichment measurement error B actually enter into the 235U LEMIF is highly dependent on processing and accounting booking practices

measurement positions (thre日)

The conveyor has one secele that precedes the tnree measurement dostliont

measurement system

menu

submenu

minor actinides

\section{MKA}

много-камальның внализатор

программа контроля измөрений

Oписамие протраммы измерений для весое

\section{длине свободного пробега}

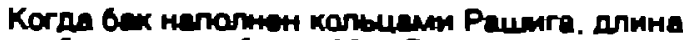

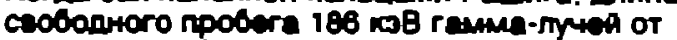

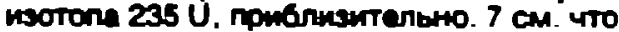

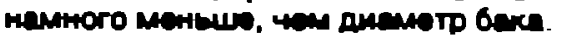

измөренная безвозератнея потөря

измерөнное знвчөние

измерение

контроль измерения

контрольные графики измөрений

программа контроля измерений

Описание программы контрола мзмерения але cecos

погрөшности измерений

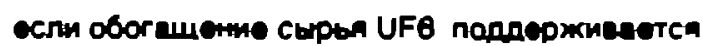

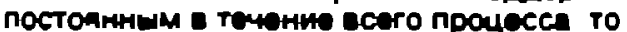
потрешности измерення урана-235 силино sasment от спос0000 06pedotion и унете .. или oumbxa измерения

ошибки измөрөний

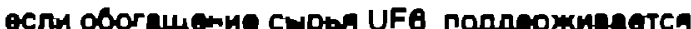

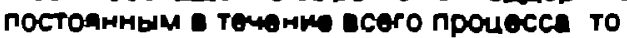
погрошности измер ния урана-235 смльно

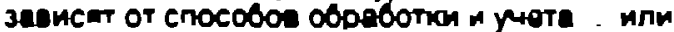
norpe UHOCTM MJM CDOMAA

измерения в трех положениях

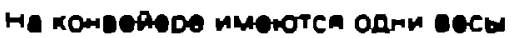
оздениелнке не которех предшестеует пзмерениям торх поломеми

систөма измерений

меню

субоменю

младшие актиниды

manpwмed неттуния 


\section{Los Alamos National Leboratory - Translation and Interprotation Sorvice}

April 6. 1995

misuse

mixed oxide

MOX

model

Devotopment and teeting of a model of a unit to monitor the integrity of containers with fiesile materials

model (generic) safeguards approach

model plant

moderation

moderator

monitor

monitoring

Equipment - based control syaterns for thems containing nuclear materiale

Otten used for monitoring. assey or measurement

MOX

mlxed oxide

MOX samples

MUF

material unaccounted for - The emall quantities of material which are not removed by rigororus dhan-outs are not included in the inventory but are trested as material unaccounted for

MUF expected value

MUF observed value

multichannel analyzer

MCA

multiplication

multiplication-corrected efficiency использование не по назначөнию

\section{смешаное оксидное топливо}

МОкС

о6разөц

Изготолиение и тестировение

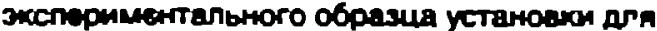

контрала сомранности контейнеро

модөльный (очобщөнный) подход применөнию гарантий

модөльный завод

замөдлөние

замөдлитөль

монитор

контроль

annapтурные средстеа контроля учетных едмниц с пдерными матерналами

\section{MOKC}

смешаное оксидное топливо

смөшанныө оксидные образцы

obpasum MOKC

KHM

когинестео неуитенного м чтериала - Малне колинесте материала не , алленные 8

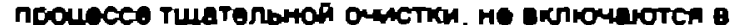

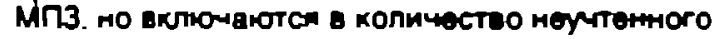
mateomara

ожицаөмоө значөния КНМ

наблюдвөмоө значөниө КНM

много-канальный анализатор

MKA

размножөния

эФФективность счөта числа рөальных нөйтронов в актах совпвдений с учөтом поправки на размножөние

Множөственность 
Aprll 6. 1995

\author{
multiplicity counter \\ mu!.Iplicity counting \\ natural uranium \\ NCC \\ NDA \\ nonde:tructive assey \\ near real-time material accountancy
}

NRTA

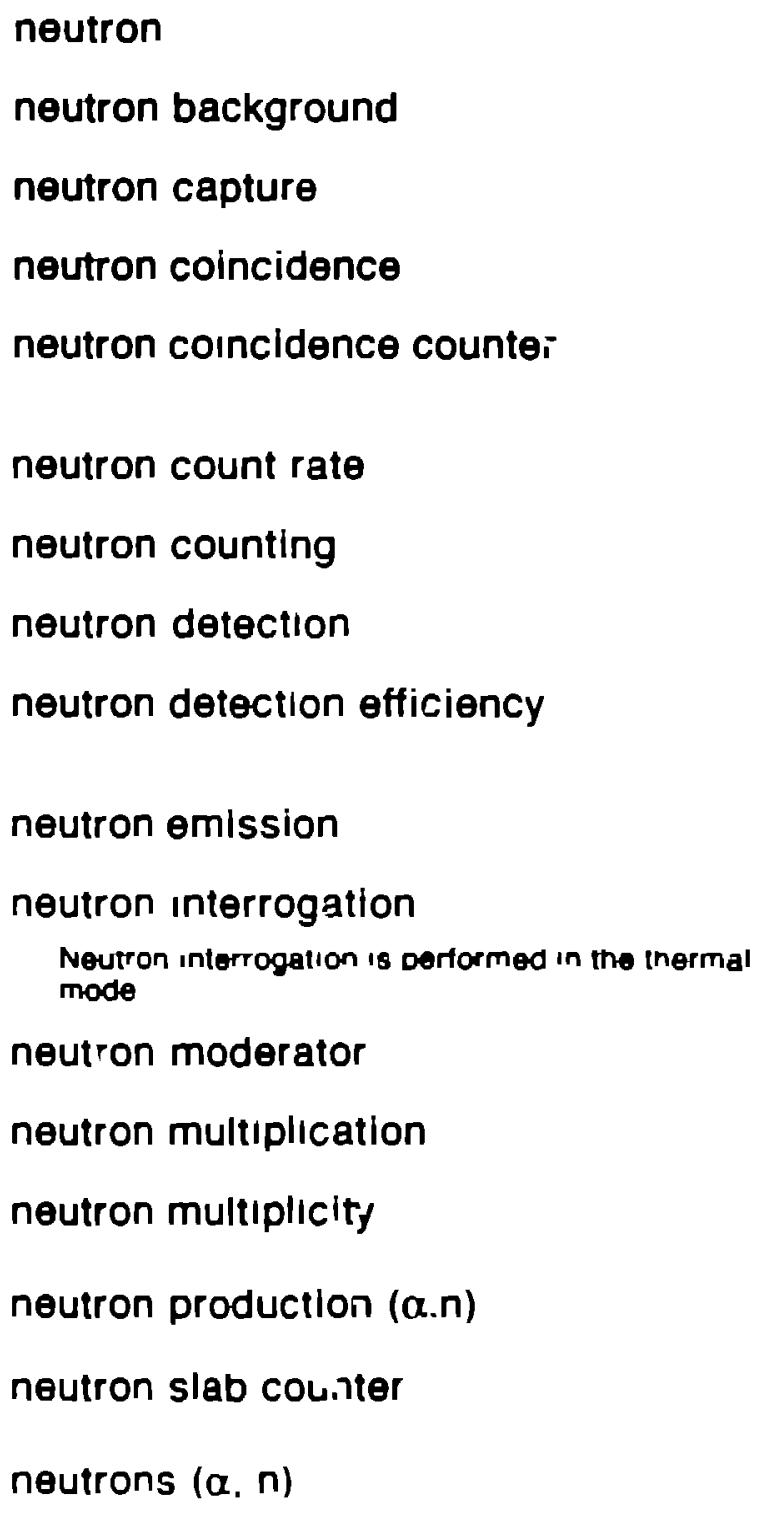

СЧөтЧИК множөствөннОстИ

счет множөствөнности нейтронов

природный уран

нөйтронныө счөтчик соөпадөний

HPA

неразрушесоиия анелиз

учет матөривла в почти рөальном масшта6е времөни

нейтрон

нейтроновый Фон

нөйтроновый захват

Совпадөния нөйтронов

счөтнкк нөйтронных совпадений

скорость счета нөйтронов

Счөт нөйтронов

регистрация нөйтронов

зффективность регистрации нөйтронов

Змиссин нөйтронов

облучөние

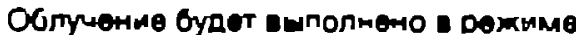

Tennosux neṕtDot+os

замөдлитөль нөйтронов

размножөние нөйтронов

множөствөнность нөйтронов

выход нөйтронов в рөакции $(\alpha, n)$

плоский нөйтронный дөтөктор

нөйтроны, испускаөмыө в рөакции

$(\alpha . n)$ 


\section{Los Aamos National Laboratory - Translation and Interpretation Sorvice}

Aprll 0. 1996

\section{NICS}

Nuclear Invertory Control System - The NICS malmains a perpetud invertory balance for internd plant MBAs and item listings for internal plent ICAs

\section{NIM}

nuclear instrument module

\section{NIOKR}

Sclentific Research Testing and Design Work this is an acromym which is not deciphered anywtiwre in the documents. From the context you can determine that it means the R\&D. onglnearing and cesign required to bring a product to the serial manufacturing stage.

nitrate ( $\mathrm{U}$ or $\mathrm{Pu})$ to oxide conversion plant

\section{NM}

Nuclear Material

NMA system nuclear materlal accountancy system

\section{NMRS}

Nuchear Material Reporing System - The NMRS maintains a perperual inventory balance for the plant as a whole. All transaction records since inception are maintained in the current cata files

NOL

normal ODerations loss

NOL

normal operations loss

non-linear

non-nuclear material

Non-Proliferation Treaty (NPT)

nondestructive assay

NDA

nonlinear

nonuniform

normal operations loss

NOL

\section{CКИКЯМ}

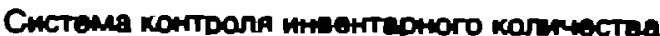
nдерного matepнara - В СКИКАМ нгодитс-

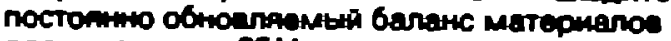

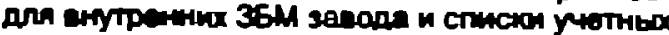

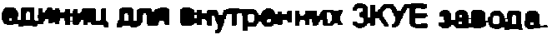

модуль Адерного прибора

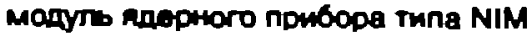

\section{HИOKP}

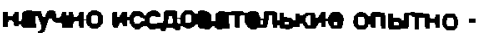
конструкторстие работы

завод по пөрөработкө нитрата (U или Рu) воксид

AM

Rдерные matenmerio

практика учета ядерных матөривлов

\section{CORM}

Cнстемa отчетности о mnерном материare В СОАМ нехоnитса постоянно обноелаемый баламс метеривлоe nлa sasona kax uenoro Bce залиси метньо операций начннал с прнемки матеонела содержатся в темуших файлах nanibo

обычныө производствөнные потөри

обычныө производствөнныө потөри

нөлинөйный

неядерный матөриал

Договор о нөраспрос- транөнии ядөрного оружия

нөразрушающий анализ

нөлинөйный

нөрввномерное

обычныө производствөнные потөри 


\section{MceA Ceneral Oloseary \\ Los Alamos Natlonal Laboratory - Tranaletion end Interpretation service}

April 6. 1996

notification

nozzle, throat

NPT

Non-Proliferation Treaty

NRC

Nuclear Regulatory Commisston

NAT

near real-tıme material eccountancy

NRTA

noar reat-fime materlal accoununcy

nuclear equipinent

nuclear fuel

nuclear fuel cycle

nuclear fuel reprocessing plant

nuclear grade graphite

nuclear instrument module

NIM

Nuclear Inventory Control System

NICS - The NICS mainiains a perpetual inventery balance for interna plant MBAs and ttem lístings for internai plant ICAs

nuclear loss

nuclear material

NM

nuclear material accountancy

nuclear material accountancy system NMA sysiem

nuclear material accounting уведомление

coño

Догомор о нераспрос- транении คдерного оружия

HPU

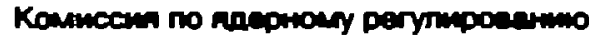

учет материала в почти реальном масштабе времени

учет материала в почти реальном масштабе времени

Адерное оборудованиө

คдерное топливо

Адөрный топливный цикл

завод по переработкө Адөрного топлива

графит ядөрной чистоты

модуль ядөрного прибора

медугі mдерного прнбора rma NIM

Систөма контроля инвөнтарного количөства ядөрного матөриала

СКИКАМ - В СКИКАМ нахопитС ПоСтоянно Обновљаемый баланс материалое для внутренних ЗБМ завопа и списки үнетных өДиниц для внутреннмк ЗКУЕ заподе.

потөря ядөрного матөриала (в рөакторе)

ядөрный матөриал

คM

практика учөта ядерного матөриала

систөма учөта пдөрных матөриалов

учөт ядөрного матөриала 


\section{Los Aemos Mational Leboratory - Trandation end Interprotation servico}

Aprit 6. 1008

\section{Nuclear Material Reporting System}

NMAS - Tho NaAS maintanes a perpetid Imventory betencs for the plant as a wholo. Al tremesction records eince inception ere mintaned in the current data files

nuclear materials custodian

nuclear materlals representative

nuclear production

Nuclear Aegulatory Commission

NAC

nuclear supplier guidelines

nucllde

off-loaded fueled power reactor

\section{OKR}

Testing and Design Work - this is an ecromm which is not deciphered anywhwre in the documents From the context you can determine that it means engineering and desion required to bring a product to the serial manufacturing stage Apparenty. as the acronym indicates this term does not include R\&D

on-loaded fueled power rea-tor

opgnıng switch

opening switch

operating records

operating report

optıcal surveillance device

other locations(of nuclear materials)

\section{Система отчетности о адерном матөриале}

COFM - B COFM Monannón noctowero

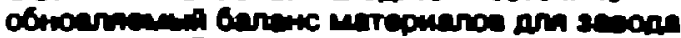

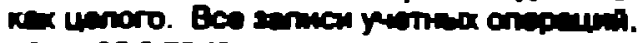

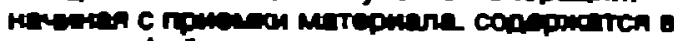

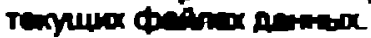

хранитөль ядөрных матөриалов

\section{представктөль ядөрных} матөриалов

производство ядерного матөривла (в реакторе)

\section{Комиссия по ядерному} регулированик

HPU

руководящие положения, принятые поставщиками ядөрного матөриала и оборудования

нуклид

энергетичөский рөактор, останавливаөмый для пөрөгрузки топлива

OKP

опьтно - конструкторские работы

энөргөтичөский рөактор. перегружаөмый на мощности обостритөль. ключ - размыкатөль ключ - размыкатөль, обостритөль эксплуатационныө учөтныө документы

зanncu эксплуатационный отчет оптическое устройство наблюдения

другиө мөста нахождения (ядерного матөриала) 


\begin{tabular}{|c|c|}
\hline \multicolumn{2}{|c|}{ Aprtt 6. 1008} \\
\hline other loseres & друтие потери \\
\hline outgassing & raskTb \\
\hline override & ипнорировать \\
\hline oxide & оксид \\
\hline $\begin{array}{l}\text { oxide (U or Pu) to metal conversion } \\
\text { plant }\end{array}$ & $\begin{array}{l}\text { завод по переработке оксида (U или } \\
\text { Рu) в } \\
\text { мөталлический уран или плутоний }\end{array}$ \\
\hline passive gamma counting & пассивный счөтчик гамма-излучөния \\
\hline 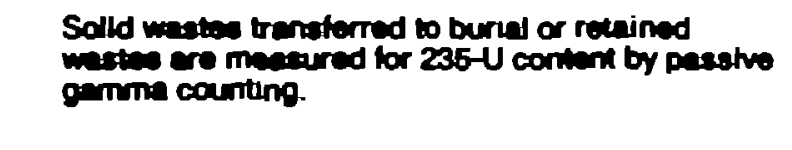 & 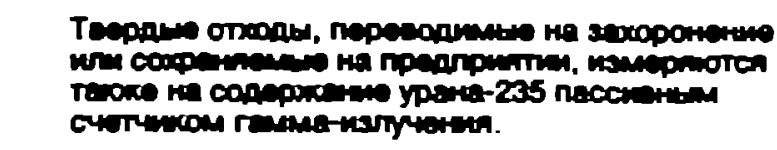 \\
\hline passive measurement & пассивные измөрения \\
\hline passportizer & пасспортизатор \\
\hline $\begin{array}{l}\text { A rediation pasesportizer for rough verification of } \\
\text { correspondince of a rese gammina specter of the } \\
\text { trensportod sesembly bo pessport dets. }\end{array}$ & 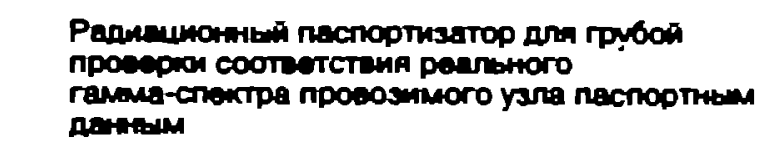 \\
\hline password & пароль \\
\hline peak (186-keV peak) & $\begin{array}{l}\text { пик, соотвөтствующий знөргии } 186 \\
\text { кэВ }\end{array}$ \\
\hline $\begin{array}{l}\text { Adjust the amplffler gain so that the } 188-k 0 V \text { peak } \\
\text { is noer chamel } 300\end{array}$ & 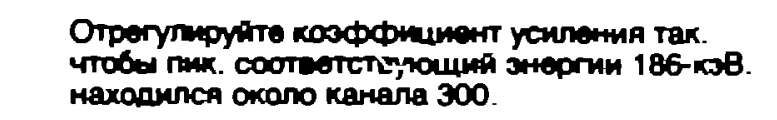 \\
\hline pellet & таблетка \\
\hline percent recoverles on standards & $\begin{array}{l}\text { отклонөние от эталонного значения, } \\
\text { өыражөннсө в процөнтах }\end{array}$ \\
\hline a measurement process mean & $\begin{array}{l}\text { одна из сгедних величин статистиноских } \\
\text { мзмерения̈ }\end{array}$ \\
\hline physical inventory & Физичөская инвөнтаризация \\
\hline \multirow[t]{3}{*}{$\mathbf{P} 1$} & Фактичөское нөличноө количөСтво матөриела \\
\hline & $\begin{array}{l}\text { Фактичөскоө наличноө количөство } \\
\text { матөриала }\end{array}$ \\
\hline & Физимоскал инвентаризация \\
\hline physical inventory listing & $\begin{array}{l}\text { список Фактичөски наличного } \\
\text { количөства матөриала }\end{array}$ \\
\hline protection & Физичөская защита \\
\hline
\end{tabular}




\section{Mcen Ceneral Gloesery \\ Los Alamos National Laboratory - Trensiation end Interpretation Service \\ April 6. 1900 \\ Фактическое наличное копичество матөриала}

PI

phyalcal trmertion

placement

plant

plasma bridge

plenum

plutonium

plutonium oxide

PMCA

portable multichennel anabzer

point of entry (personnel)

point of entry (vehlcle)

point of transit (hand cielivery)

Puint through which esthorized nucloes mo erialds are delivered to or shipped from a facility

point of transit (vehicle)

Polnt through which euthorized nuclear materials are delivered to or shipoed from a lacility

polyethelene

portable multichannel analyzer

PMCA

portal

portal monitor

the poral moniter wicn is located in the vicinity of the eniry gales gives the signal indicaling that a rallroad car has passod and contains lissile material

post-shoot (report)

powder

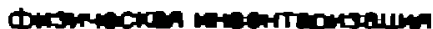

размещение

завод

плазменная пөрөмычка

вөнтиляционная квмөра

плутоний

оксид плутония

портативный много-канальный анализатор

пөшөходный проход

проөзд для транспорта

пункт проноса

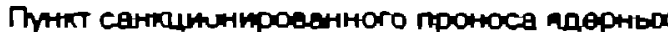
Mateomanoe.

пункт провоза

Пулнт санкиноншроманного проеоза пдерных Matopmanoe

полиэтилен

портативный много-канальный анализатор

портал

портальный монитор

портельньй монитор раслоложөнтый в районе

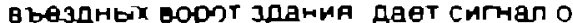

прохомдетни вагона и нали ини в нем ДМ СУнК

постшут

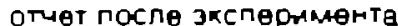

отчет после экспөримента

- ПостUут - - DQзговорнный төDMнт

порошок 


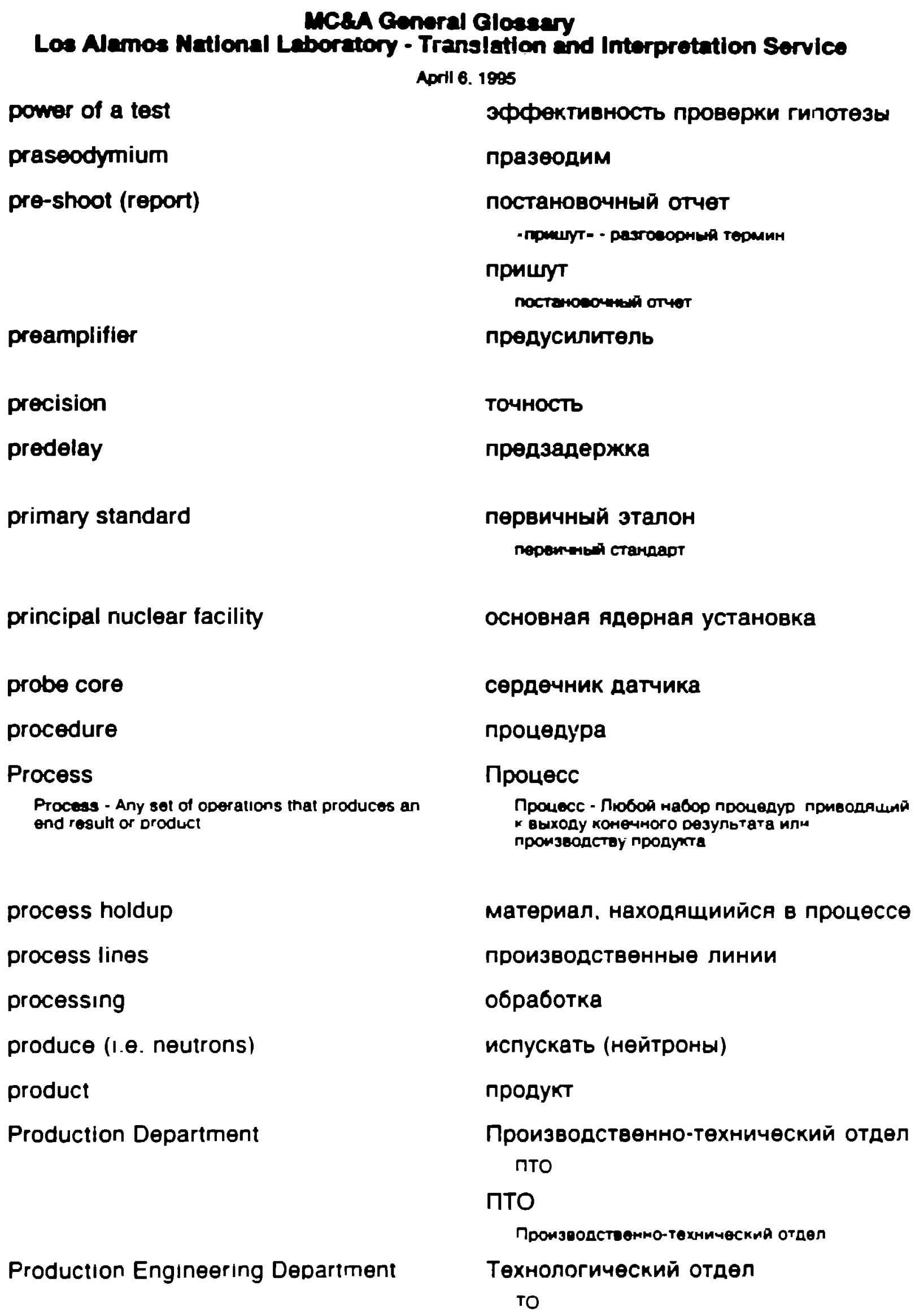




\section{Mcesa General Gloesary \\ Los Alamos National Laborat xy - Translation and Interpretation Sorvice}

April 6, 1995

Production Engineering Department

project agreement

protected area

protracted theft or diversion

pulse pileup

pulse-processing electonics modules

Pulse-processing otectonics modules ( Inside the junction box above the 3 He tubes) produce digral neutron pulses for subsequent lime-correlation processing and counting circults.

pyrochemical

pyrochemical multiplicity counter

qualification

quality assurance

quality assurance plan

Quality Control Department

quallty control foreman

quarantıne tank

Each process line incluaing scrap recovery nas win benks ol Quaranline lanks where the volume of centriluged process ethiuent is measured and ine solution sambled prior to transler to ine lapoons

\section{quencher}

rack mounted

radiation passage monitor

random error

random sampling
TO

Texomormacroup otgen

соглашение о проекте

защищенная зона

длитөльное хищение или переключөниө

зашкаливание из-за высокой
интөнсивности импульсов

элөктронныө модули прөобразования импульСОв

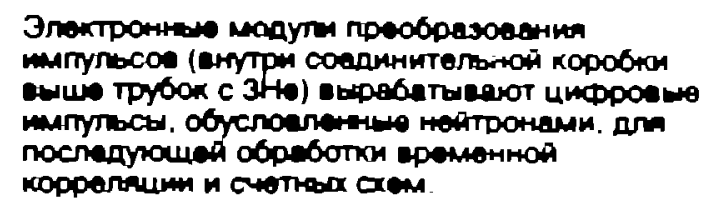

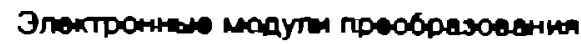

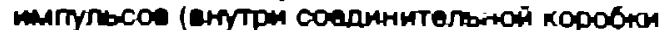

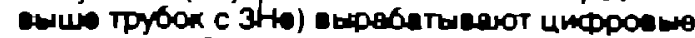

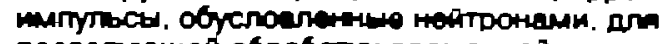

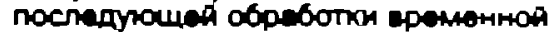
coppartum и custrobx crea.

пирохимический

пирохимичөский счөтчик МнОЖөСтвөннОСТИ

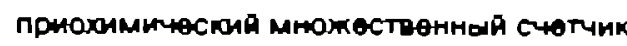

аттөстация

завөрение качөства

план завөрөния качөстөа

OTK

мастөр OTK

карантинный бак

У каждой төхнопогической линин еключая

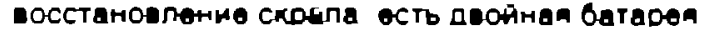

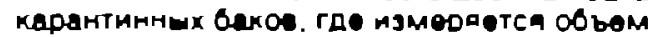

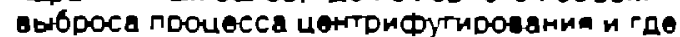
beoytca ODDajum pactmopa neded ton kak oro

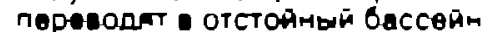

эубоотсөкатөль

закрепленый на стройкө

радиационный монитор для прохода

случайная ошибка

вьборка на случайной основе.

случайность 


\section{MCen General Gloseary \\ Los Alamos National Laboratory - Transiation and Interprototion servico April 6, 1998}

rate loss source

rate-loss corrections

raw data

RBMK reactor

react (with)

reactor

reactor - advanced gas cooled reactor

AGP

reactor - fast breoder reactor

reactor - fast breeder reactor

reactor - heavy water reactor

HWR

reactor - high temperature gas cooled reactor

HTGR

reactor lattlce

reactor - Magnox reactor

reactor - materials testing reactor

reactor - off-loaded fueled power reactor

reactor - on-loaded fueled power reactor

reactor power monitor

reactor - research reactor

reactor - TRIGA

reagent

reals источник для определения потөри скорости счетв

поправки на потере скорости счөта

пөрвичные данные

pөaктор PБMK

реатировать

реактор

усовершенствованный

газоохлаждаөмый рөактор

быстрый рөактор - размножитөль

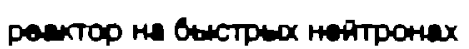

рөактор на быстрых нөйтронах

быстрый реаттор- резмнотктель

тяжеловодный рөактор

высокотөмпературный

газоохлаждаөмый рөактор

конфигурация реактора

Maгноксовый рөактор

реактор для испытания матөриалов

энөргетичөский рөактор,

останавпиваөмый для пөрегрузки топлива

энергетический рөактор, пөрөгружаөмый на мощности

монитор мощности ревктора

исследовательский реактор

pөaкTOP TRIGA

рөактив

число рөальных нейтронов в актах совпадөний 


\section{mcerA General Oloseny \\ Los Alamos National Leboratory - Translatton and interpretation servico}

Aprill B, 1800

reals vs mass

reconciliatilion

records

reference material

reference value

referential integrity

database progrem Microett Access.

Changes done in primery Helds are made acroas

the whiole database for al linked Lables, otherwice

no chenges are mede at all

reflection geometry

The experiments were repented using

aimulteneous detection of traneient intrared laser

abiorption (In a raflection geometry) and transient infrared emisoion.

reglons of interest

ROIs

relay switch

removal (chemistry)

report

representative sampling

reproduction

Are woll reproduced by the equation of state

research and development facllity

research reactor

residual blas число нейтронов в Функции массы

cornacoвание

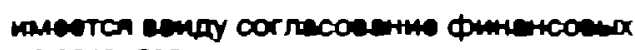
Domprimarton

документы

senucas

записи

nonywarty

эталонный матөриал

опорное значение

ссылочная интегрированность

Мзмененип В одном мосте влақут нзменения :

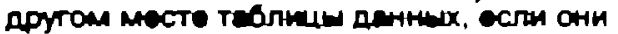

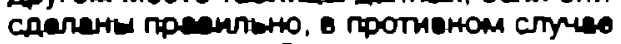

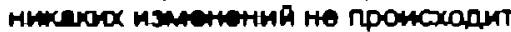

в гөомөтрии отражөния

рассматриваөмые области

$\mathrm{PO}$

рөльсовый пөрөключатөль

отщеплөниө

OTY

представительная өыборка

воспроизвөдение

Хорошо өоспронзеодатся уроенением COCTOATHA

исслөдоватөльская и оПЫTHO-КОНстрУкторская установка

исслөдоветөльский рөактор

остаточное смещения

мли ошмока 


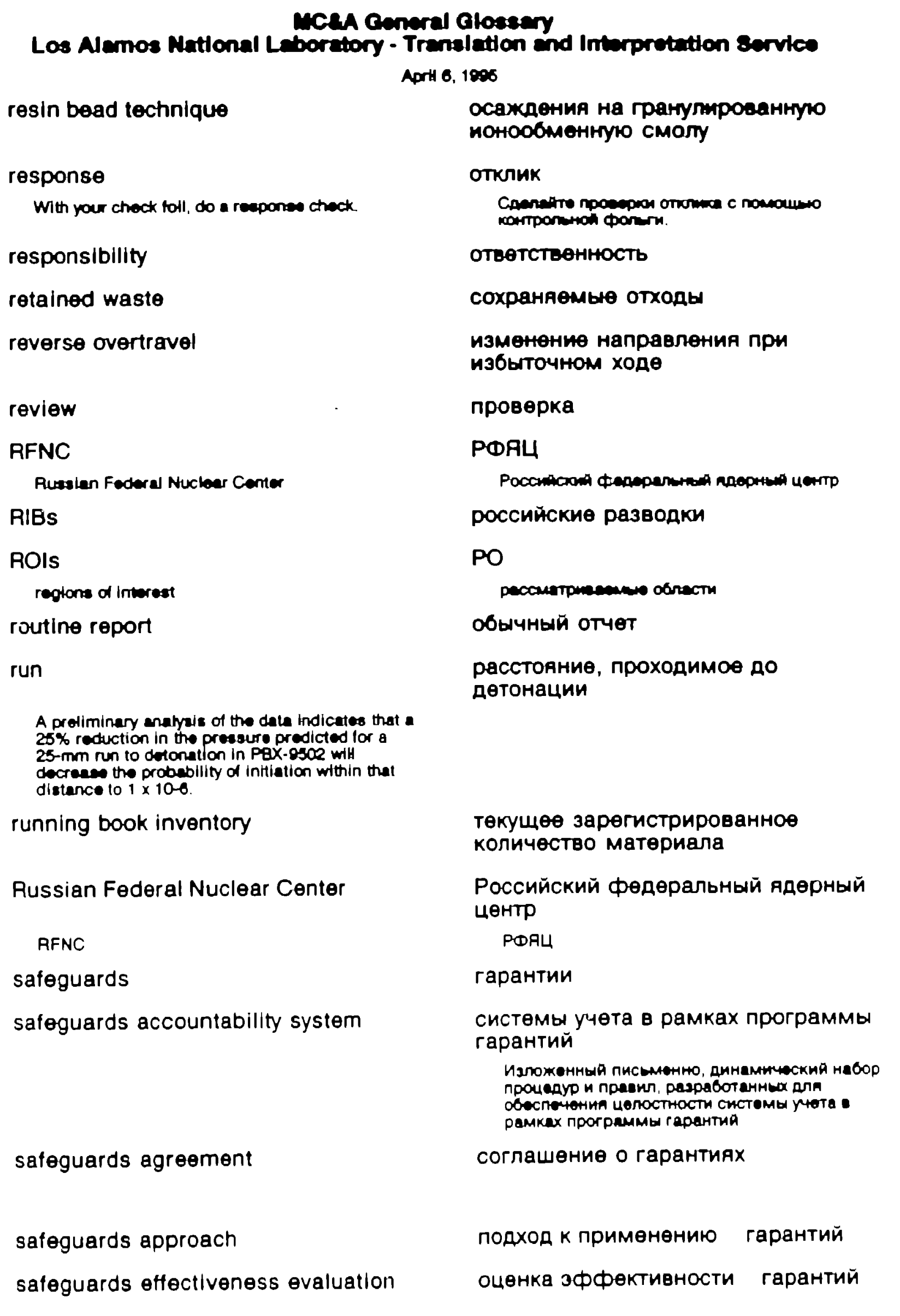




\section{Mcera General Oloseny \\ Los Aamos National Leboratory - Translation and Interprotation Sorvice}

April 6, 1885

\author{
safeguards implementation \\ safeguards interface \\ safeguards requirements \\ ...an approach meating U.S. sateguards \\ requirements

\section{Safeguards Systems Group \\ Loe Alemoe Nationd Laboratory Administrattive Group \\ sateguards uses of confirmatory measurements}

\section{SAM}

stabilized eseny moter

sample

\author{
Samplo taking \\ sample mean and variance

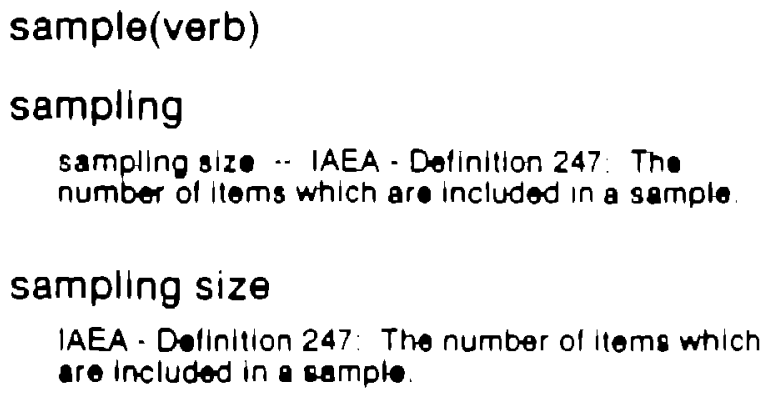

осуществлөние гарвнтий

на стыкө с систөмой гарантиями

трөбования систөмы гарантий

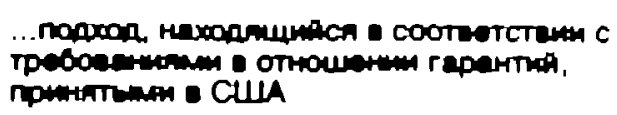

\section{Группа по системам гарантий}

Апинистретиенор подразделени Пос

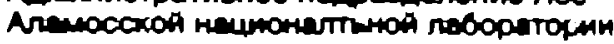

использоеание подтверждающих измерений для систөмы гарантий

стабилизированный анализатор, измөритөль

\section{образөц}

Oт6ор про0- - kоrде perw идет о

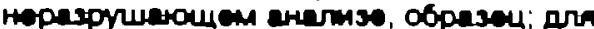

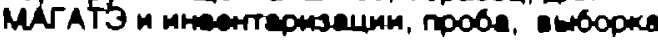

вuбOpкa

OTbop npobt - koral poyb nat o

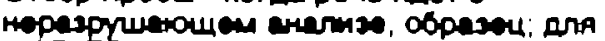

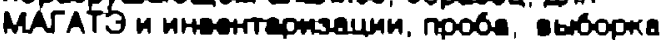

про6а

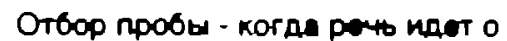

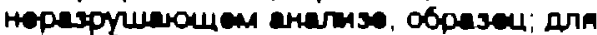

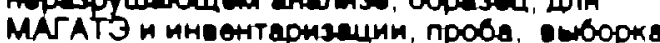

среднөө значөние и дисперсия внборки

брать пробу (выборку)

\section{вы6орка}

ралмер ü6орки -- MAГАТЭ - OпределенHе NO

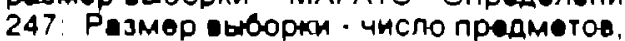

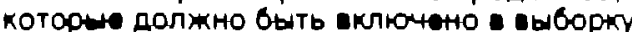

\section{размер выОорки}

MAГАT3 - OnределенHe NN 247: Размер - НОоки - Чнсло Предметое, которые должно

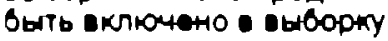

сканнөр

СЦИНтИЛЛАЦИОННЫЙ ДөтөКтОР

ckpan

завод по рөгөнөрации скрапа 
Los Alemos Mational Leboratory - Translation and Interprotation Sorvice

April B, 1995

seal

seal

seal control program

seal custodian

sealed

cannod

sealed, hermetically

hermetically seabed container

sealed source

secondary standard

securlty area

segmented gamma scanner

self-sustaining detonation wave

The "pop-plot" for an explosive is a two-paran ete quentitative relationship between ine initial inp. It pressure and the distance from the input lace 10 the lormation of a self-sustaining detonation wave

selfmultiplication

semiconductor detector

senior foreman

shape charge

$\operatorname{shap\theta }(d)$

shiold пөчать

nnowore

плом6а

noutro

программа контроля плом6

лицо отеөтственное за пломбы

упакованный

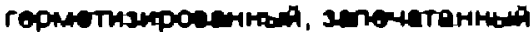

запөчатанный

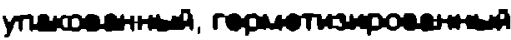

капсулированный

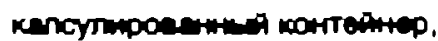

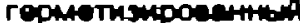

гөрмөтизировєнный

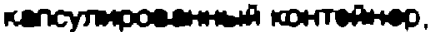

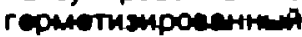

гөрмөтизированный источник

вторичный стандарт

-тоOананы ттелон

вторичный зталон

-TOPAнHA стандарт

зона безопасности

сөгментированное гамма-

сканирующеө устройство

самоподдерживающаяся

дөтонационная волна

саморазмножөние

полупроводниковый детөктор

старший мастөр

КУммУляционный заряд

Формирующий

экран 


\section{MCRA General Gioseary \\ Los Alemos National Laboratory - Translation and Interprotation Service}

April 6. 1995

shift register clock

shipper receiver confirmatory system

shipper/receiver difference

shop economist

shop manager

shop production engineer

shorten (verb)

significance level

significant quantity

so

significant records

simple propagation of the errors in the totals and reals

\footnotetext{
Using simple propagation of the errors in the totals and reals, the resulting precision in the

multiplication-corrected reals (Rc) renged betwilin 0.08 and $0.1 \%$
}

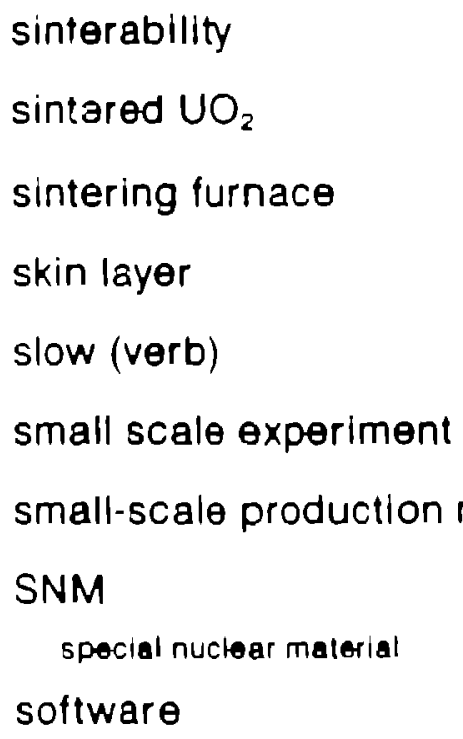

регистрирующие сдвиг часы

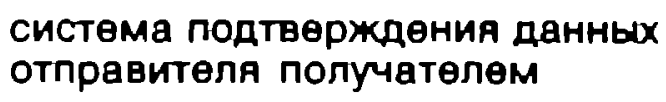

расхождение в данных отправителя 'я получатөля

экономист цөха

начальник цөха

төхнолог цеха

укорачивать

уровень значимости

эначимое количөство

Зк

значимые учөтные документы

sanuch

мөтод простого расчөта

рөзультирующих ошибок ихмөрөний числа нөйтронов в актах совпадөний и полного числа нейтронов

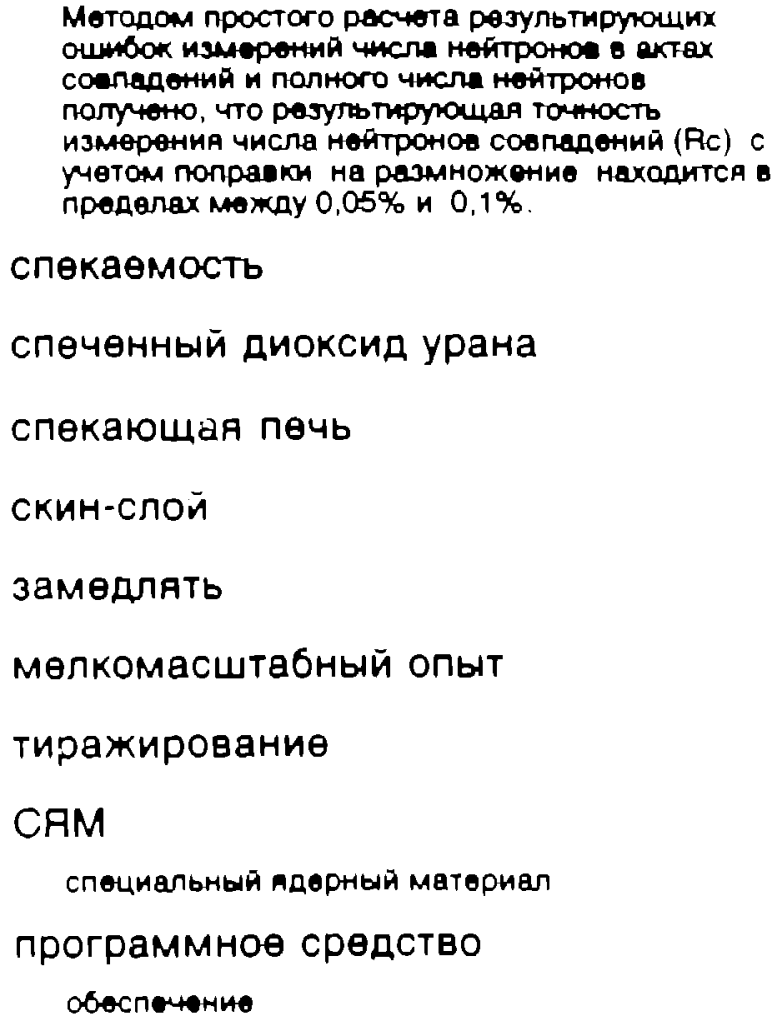




\section{Mcen General Glosesery \\ Los Aamos National Leboratory - Translation and Interpretation Sorvice}

April 6, 1895

\author{
software \\ solid angle \\ source \\ source material \\ source transactions \\ spatial neutron passportization system \\ Introduction and placement into operation of a \\ spatial noutron paesportization syatern at one of \\ the exieing VNIIEF otorego tacilities. \\ special nuclear material \\ SNM \\ speclal physical inventory \\ special report \\ spectrometry \\ spontaneous fission
}

spontanөous fission neutrons

spontaneously

SO

significant quantity

SSAC

State system of Accounting and Control

stabilized assay meter

SAM

standard

standard devlation (s)

standard error of blas программное обөспөчөние

cpancteo

төлөсный утол

Источник

исходный матөриал

опөрации приөмки матөриала

система пространственной пасспортизации

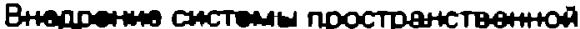

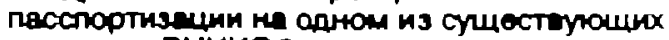
(p)

специальный ядерный матөриал

CAM

спөциальная физичөская

инвөнтаризация

спөцальный отчөт

спөКтромөтрия

спонтанно дөлящиөся

нөйтроны спонтанного дөлөния

спонтанно

$3 \mathrm{~K}$

ЗначнмОе количестеО

ГCУиK

Государстеөнная снстема учета и контрпля стабилизированный анализатор, измөритөль

эталон

stampep

стандарт

эталон

стандартное отклонение (я)

стандартная ошибка смөщения 


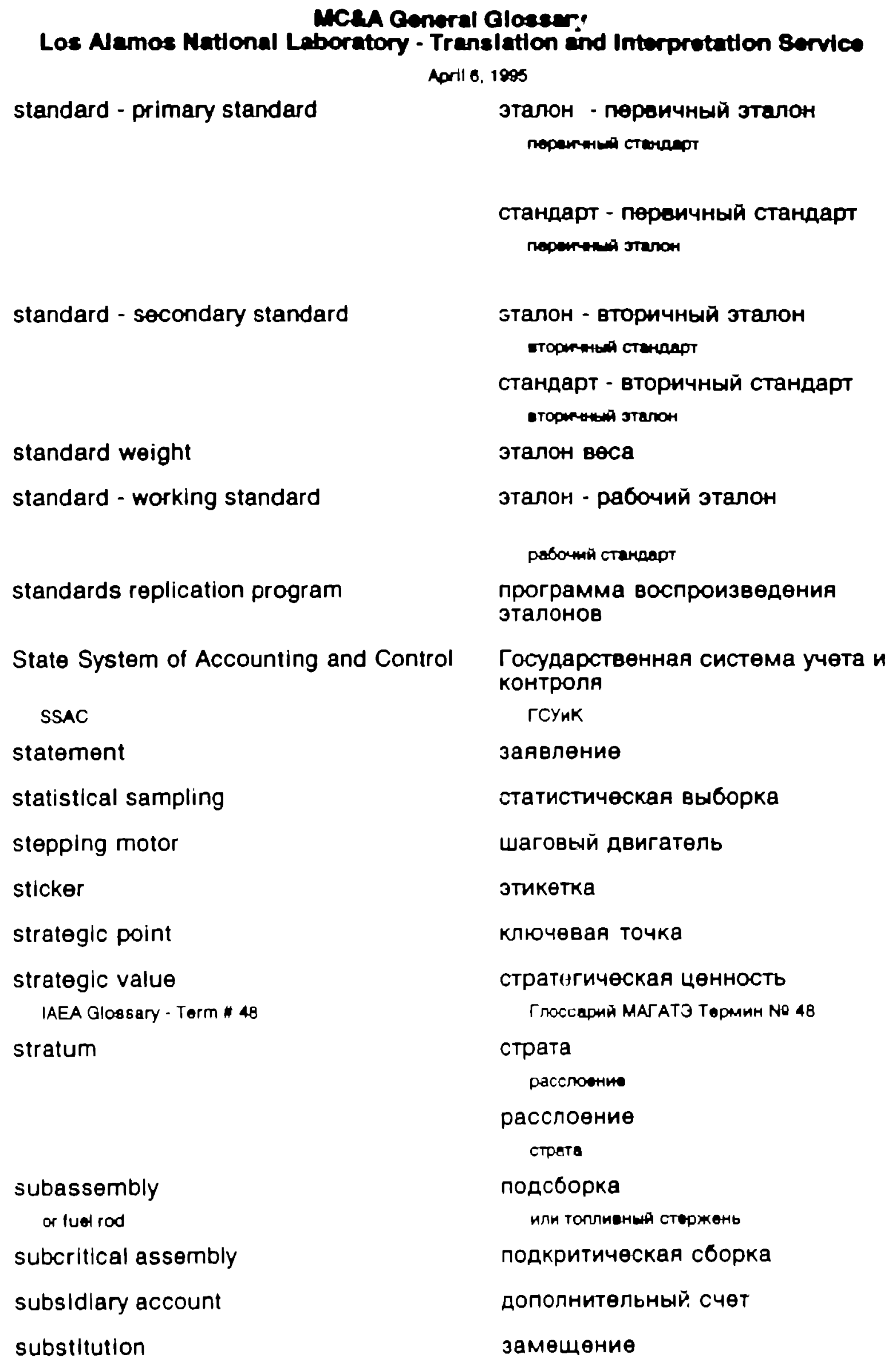

Государствөнная систөма учөта и Контроля

ГСУнK

заявление

статистичөская вы6орка

шаговнй двигатөль

этикөTKa

ключөвая точка

стратөГичөская ЦLөнноСТЬ

Г поссармй МАГАТЭ ТорАнH NN 48

страта

paccroonite

расслоение

стрета

подсборка

илн топлменше стержень

подкритичөская сборка

дополнительныг̆. СЧөт

замөщөниө 


\section{MCeA General Gloseary \\ Los Alamos National Laboratory - Translation and Interpretation 8ervice}

April 0, 1895

subtraction

supervisor module

supporting documents

surface ionization mass spectrometry

surveillance

switch

synch pulse

system

Radiation monltoring systems at controlled acces points. Term inctudes equipment, instruments. methods, and oven administrative procedures.

Introduction of the radiation passportization systems for test operations al VNIIEF

sy'stem(s)

systematic error

systematic sampling

$T \cdot$ connector

talls

tamper resistance

tamper safing

tamper-Indicating seal

tampering

tampering indicator device
Вычет

управлаюІций модуль

вспомсілтөльные документы

магс-спектромөтрия с повөрхностной ионизациөй

наблюдение

ключ

синхроимпульс

средство

Срадстеа коrтpon ДМ на КПП

комплект аппаратуры

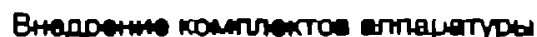

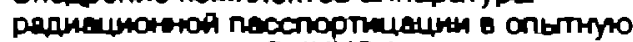

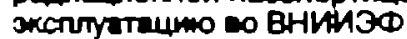

систөма(ы)

систөматичөская ошибка

систөматичөская вы6орка

тройник

шлак

противодөйстөие вмөшатөльству

противодейтеие нарушенню

повышөние безопасности

противодействием вмөшатөльству

пломба регистрирующая

вмөшатөльство

вмөшатөльство

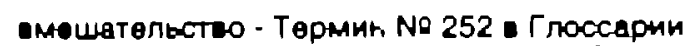

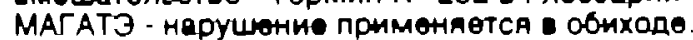

нарушения

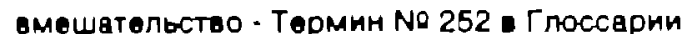

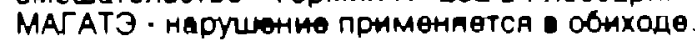

устройство рөгистрирующөө вмөшатөльство (наружөниө)

TID 


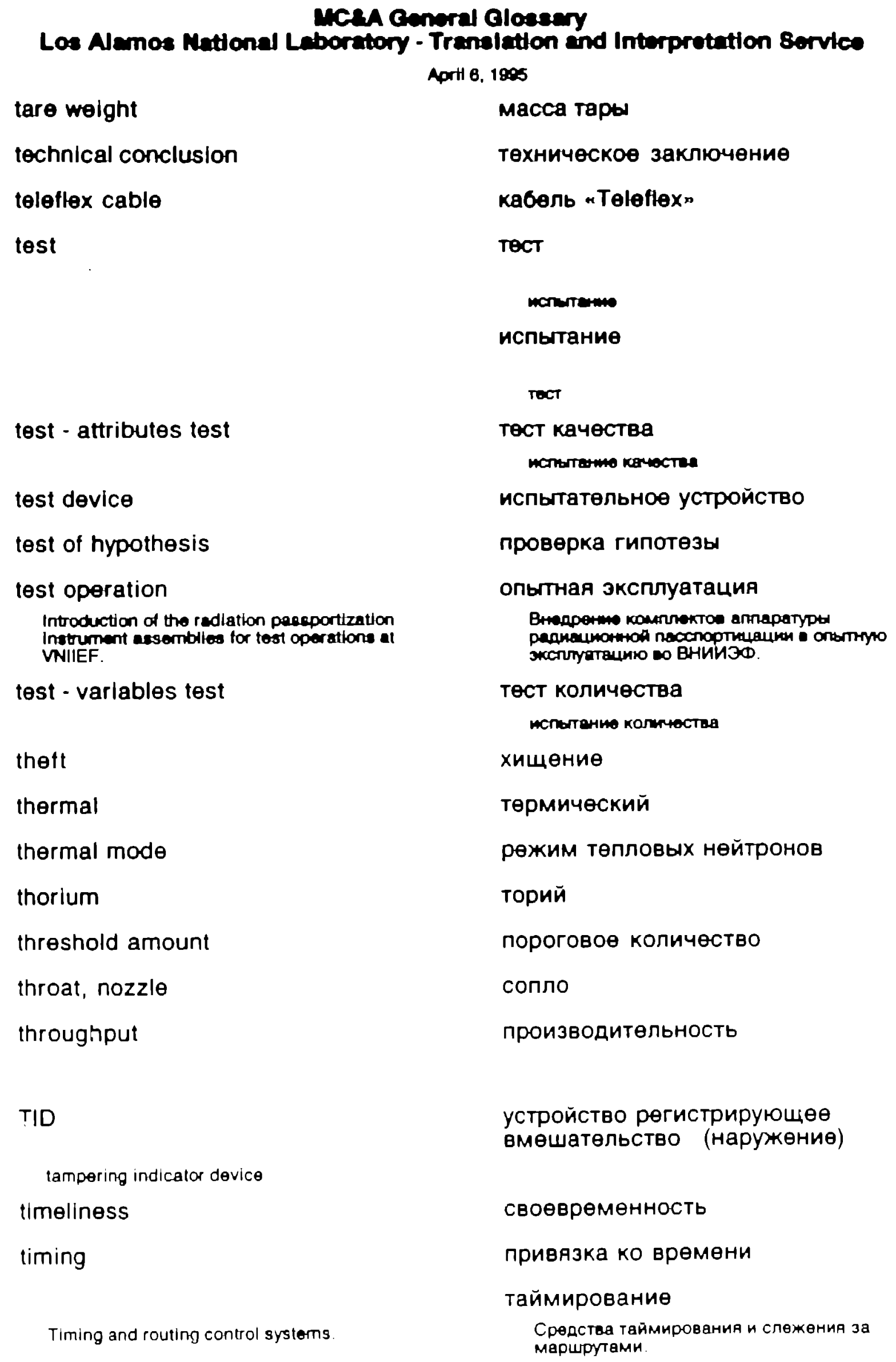

tare weight

technical conclusion

teleflex cable

test
test - attributes test
test device
test of hypothesis
test operation
Introduction of the redlation pesaportization Inatrument assemblles for tost operations at VNIIEF

test - variables test

theft

thermal

thermal mode

thorium

threshold amount

throat, nozzle

throughput

TID

tampering indicator device

timeliness

timing

Timing and routing control systerns

\author{
мacca тары \\ төхничөское заключение \\ кабель "Teleflex" \\ TөCT
}

\author{
monurterme \\ испьтание \\ Toct
}

Төст качөства

mothtramo kanoctea

испьттатөльноө устройство

провөрка гипотөзы

опытная эксплуатация

Внедрания комнлекто агтаратуры

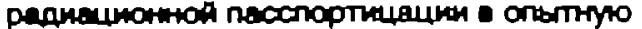

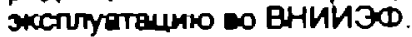

төст количөства

мспитани колинестея

хищения

төрмичөский

рөжим төпловых нөйтронов

торий

пороговое копичөство

сопло

производительность

устройство регистрирующеө

өмөшатөльство (наружөниө)

Своевременность

привязка ко врөмени

таймирование

Средстеа төймирования и слөжения за маршрутамн 


\begin{tabular}{|c|c|}
\hline \multicolumn{2}{|c|}{ Aprtt 6, 1905} \\
\hline timing data chart & врөмөнная диаграмма \\
\hline total count rate & попная скорость счета \\
\hline traceability & сопоставимость \\
\hline \multirow[t]{4}{*}{ training } & трөнировка \\
\hline & ooproureso \\
\hline & обучөниө \\
\hline & Tpermponenge \\
\hline \multirow[t]{4}{*}{ transaction } & опөрация \\
\hline & 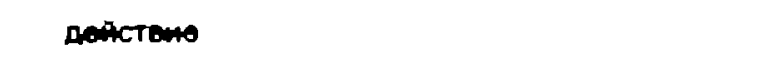 \\
\hline & дөйствиө \\
\hline & onepaunin \\
\hline transfer & пөрөдача \\
\hline transfer check & провөрка пөрөдачи \\
\hline transfer- external transfer & пөрөдача - внөшняя пөрөдача \\
\hline transfer - internal transfer & пөредача - внутрөняя пөрөдача \\
\hline $\begin{array}{l}\text { transfer key measurement point } \\
\text { transfer KMP }\end{array}$ & пөрөдаточная ключевая точка \\
\hline translator & $\begin{array}{l}\text { пөрөмөщающөө устройство } \\
\text { (пөрөмөщөниө по горизонтали) }\end{array}$ \\
\hline Iransmission & козффициент прохождөния \\
\hline \multirow[t]{3}{*}{ transmisston obeys multiplicative relationahips } & 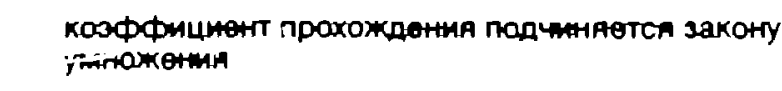 \\
\hline & коэффициөнт пропускания \\
\hline & 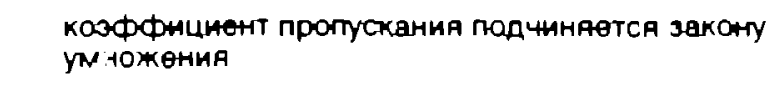 \\
\hline transmission source & $\begin{array}{l}\text { источник, используемый для } \\
\text { измөрөнмя пропускания }\end{array}$ \\
\hline transmutation & трансмутация \\
\hline TRIGA & рөактор TRIGA \\
\hline two-point energy callbration & калибровка по двум точкам энөргии \\
\hline type l error & оши6ка первого рода \\
\hline type II error & оши6ка второго рода \\
\hline
\end{tabular}




\section{marA Ganeral Gloaeary \\ Los Alamos Mational Leboratory - Trensiation and Interprotation sersico}

Aprt 6, 1998

\author{
$U_{3} \mathrm{O}_{6}-U F_{6}$ conversion plant \\ UF, cylinder heel \\ $\mathrm{UF}_{6}-\mathrm{UO}_{2}$ comversion plant \\ uncertainty \\ uniform
}

unique identification (facility)

unit

Development and teating of a model of a unit to monitor the integrity of containers with fiesile materiate

United States Industrial Cooperation usic

unmeasured loss

unreported nuclear material

unsealed

uranium

uranium- highty enriched uranium HEU

uranium - low enriched uranium

LEU

uraniun - natural uranium

uranium oxide

user interface

USIC

United States Industrial Cooperation

variables test

variance завод по переработке U⿻ $\mathrm{U}_{3}$ в UF. остатки UF. в цилиндрах завод по переработкө UF, в $\mathrm{UO}_{2}$ нөопрөдөленность равномерное onropazroos однородное paranomeproe

униакльная идөнтификация (установки)

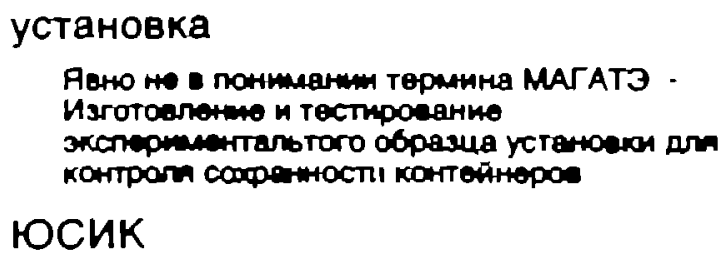

дисперсия 


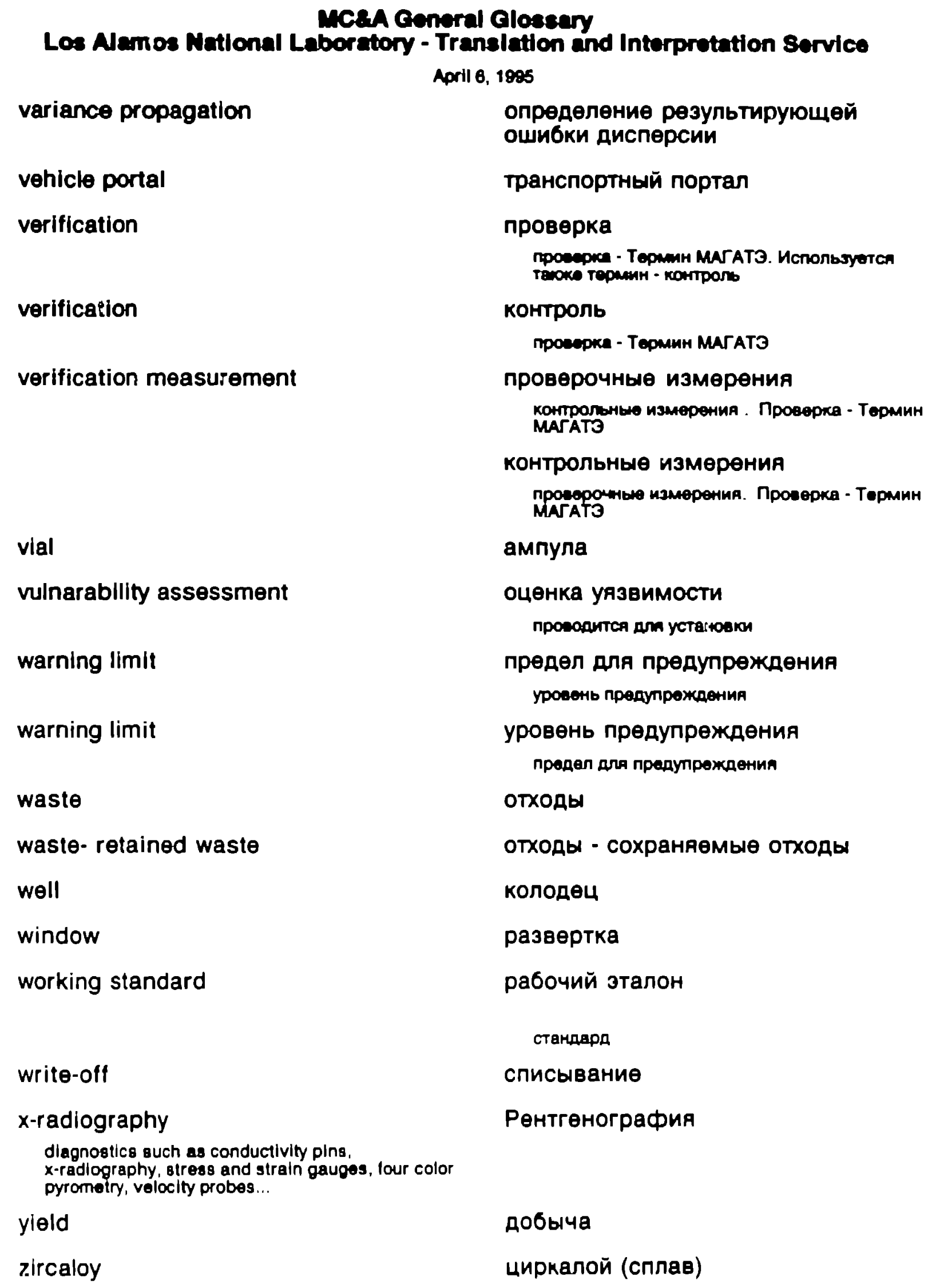




\section{РУССКО - АНГЛИЙСКИЙ ГЛОССАРИЙ}

MC\&A General Glossary

Los Alamos Natlonal Laboratory - Translation and Interpretation Sorvice

6 Aprll, 1995

\author{
200-литровыө мөталличөские бочки

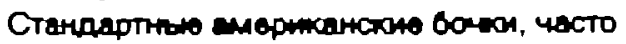

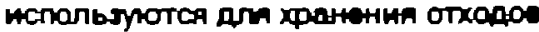 \\ 200-литровые металлические бочки

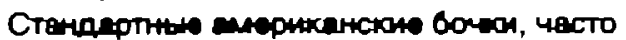

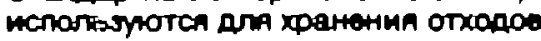 \\ аварийная потөря \\ автоматизированная систөма
наблюдөния \\ Агөнство по контролю над \\ вооружөниями и разоружөниөм \\ (AKBP) \\ AKBP
}

административная провөрка

AKBP

Aгенство по контролю над вооруженнлми н разоружениям

активная вставка, с 6ьстрыми

нөйтронами

активное измөрөние

активный рөжим работы на быстрых нөйтронах

активный режим работы на төпловых нөйтронах

активный колодөзный Счөтчик совпадений

активный счөтчик совпадөний колодөзного типа

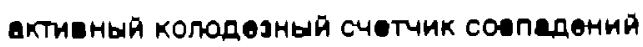

альфа частицы

Американское ядөрное общөство drums (55 gallon)

fifty-five gallon (200-liter) drums

accidental loss

automated surveillance system

Arms Control \& Disarmament Agency

ACDA

administratlve check

ACDA

Asme Controt \& Disarmament Agency

active, fast mode insert

active measurement

active-fast mode

active-thermal mode

active well coincidence counter

AWCC

AWCC

active woll colncidence counter

alpha particles

ANS

American Nuclear Socisty 


\section{MCenA General Gloseary \\ Los Alamos National Laboratory - Transiation and Interpretation Borvice}

April 6, 1985

\begin{tabular}{|c|c|}
\hline Амөриканскоө ядерноө общество & $\begin{array}{l}\text { American Nuclear Society } \\
\text { ANS }\end{array}$ \\
\hline амөриций & americlum \\
\hline ампула & vial \\
\hline анализ & assay \\
\hline анализ, изотопный & assay, isotoplc \\
\hline анализ, химичөский & analysis, chemical \\
\hline анелиз совпадөний & coincldence assay \\
\hline анализатор & analyzer \\
\hline $\begin{array}{l}\text { аналогово - циФровой } \\
\text { пөрөобразоватөль }\end{array}$ & $\begin{array}{l}\text { analog-to-digltal converter } \\
A D C\end{array}$ \\
\hline $\begin{array}{l}\text { аналогово - цифровой } \\
\text { пөрөобразоватөль }\end{array}$ & $\begin{array}{l}\text { ADC } \\
\text { analog-to-digltal converter }\end{array}$ \\
\hline аномалия & anomaly \\
\hline $\begin{array}{c}\text { E.1паратура } \\
\text { npubopt }\end{array}$ & instruments \\
\hline арифмөтичөская правильность & arlthmetic correctness \\
\hline $\begin{array}{l}\text { атөнюатор } \\
\text { ослабитель, делитель }\end{array}$ & attenuator \\
\hline аттествция & qualification \\
\hline аттөстационныө :13мөрөния & certification measurement \\
\hline аттөстованный эталонный матөриал & $\begin{array}{l}\text { certified reference material } \\
\text { CRM }\end{array}$ \\
\hline аттөстованный эталонный матөриал & $\begin{array}{l}\text { CRM } \\
\text { cortifled rolorence material }\end{array}$ \\
\hline баланс матөриплов & material balance \\
\hline
\end{tabular}




\section{MCeA General Gloseary \\ Los Alamos Mational Laboratory - Tranelation and Interprotation servico}

April 6, 1995

Gap код

штрихоео код

бөзвозвратная потөря

бөзцентровая шлифовальная установка

6roк

creme

6лок инициирования

paseonka

6лочки

АНСКИ, TаÖNTKK

6op

брать пробу (выборку)

бухгалтөрский финансовый учөт

бухгалтерия двойного учета

GDC

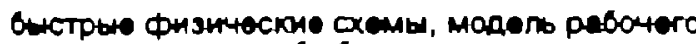

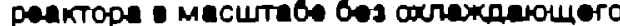

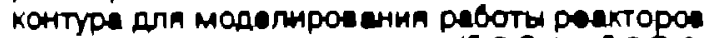

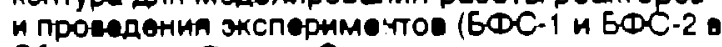

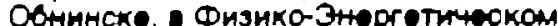

Институте)

быстрые физические схемы

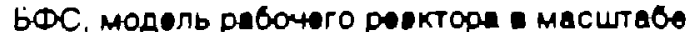
Qอง охлакдающего коттура длА моделироеания padotw реакт оро и проеедениन วКспериментое (БОС.1 и БОС.2 - ООННHCKе,

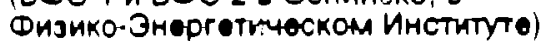

ОЫстрый рөактор- размножитөль peakтор на быстрых нейтронах

бЫстрый рөактор - размножитөль

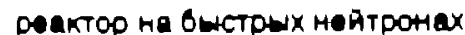

Оыстрый реактор - размножитөль реактор на Оыстрых нейтронах

бюретка, автоматичөски записывающая расходуемо КоЛичөство титранта barcode

discard

centerless grinder

circuit

Initiation block

disks

research pellets

boron

sample(verb)

financial accounting

double-entry bookkeeping

BFS

- full-scale model of a working reactor withoul the cooling loop for conducting research and imitating roactor processes a. id emergencles (BFS-1. BFS-2 at Otninsk, IPPE)

BFS

a full-scate model of a working reactor without the cooling loop for conducting rosearch and imitating reactor processes and emergencies (BFS-1.

BFS-2 at Otninak, IPPE)

fast breeder reactor

reactor - fast breeder reactor

fast breeder reactor

automatic recording titrater 


\section{MceA Ceneral Gloasery
Los Alamos Natlonal Laboratory - Translation and Interpretation Service}

April 6, 1905

в гөомөтрии отражөния

вөнтиляционная камера

вөроятность ложного срабатывания сигнала тревоги

вероятность обнаружения

вөроятность обнарукөния мөрами учетв

взаимозввисимое

взрывчатое вөщөство в виде транул

ВиTOK

вмөшатөльство

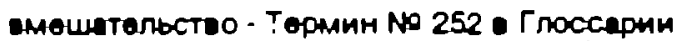

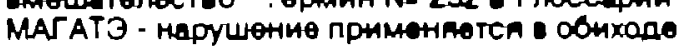

\section{внедрөние}

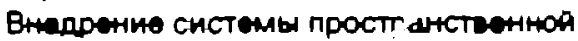

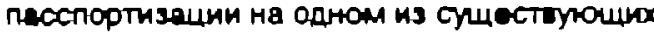
хранилищ ВНИИЗО

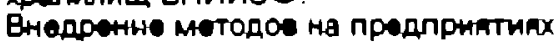
MUHATOMA

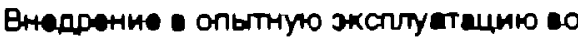
ВНИИЗФ КОмплекто раднационноң пвспортизацни.

\section{внөплановая Инвентаризация \\ Она проеодитса дла проеерки соответстана

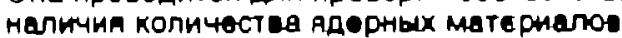

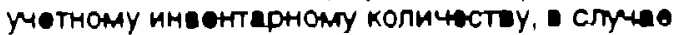

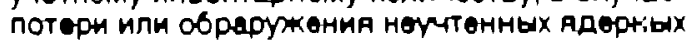 матерналоп}

внешние факторы

внө山ная блокировка накопления импульсов

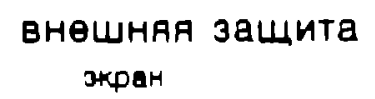

внөшняя пөрөдача reflection geometry

The experiments were reparted ualing simutianeoul defection of transient intrered Laser bacoption (in a refiection geometry) and transiemt intrered emilavion.

plenum

false alarm probabllity

detectlon probability

accountancy detection probability

\section{Interrelational}

granular explosives

In an eftort to quentily the permeability of granular becte, Shepherd end begeal pertormed both quesistatic (olase baeds and thres grenular oxplostues: CP, HMX, and HNS)

coll

tampering

incorporate

alwo : Introduce

Incorporation of a spetial neutron pessportization Eyotern at one of the exising VNIIEF storage teciltties.

When referring 10 mothods:

Incorporation of gamma spectrornetry mothods at MINATON onterprises

Introduction of the radiation passportization

syztems for tent Operations at VNIIEF

inventory outside the plan

An inventory outside the plan conducted to chack if the phraical inventory of nuclear materials matches the accounting inventory amounts.

external factors

external pileup rejection

external shield

$e^{v+e r n a l ~ t r a n s t e r}$ 


\section{MceA General Gloseary
Los Alamos National Laboratory - Translation end Interpretation servico}

April 6, 1995

\author{
внутренняя передача \\ внУТРеннАя прОверка \\ внутрикамерный шафлер \\ вода из-под шльфовки \\ ворота (или имтульс оттирания и \\ запирания) \\ воспроизведения

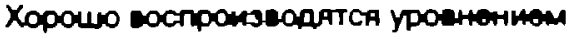 \\ coctorsma. \\ воспроизведения

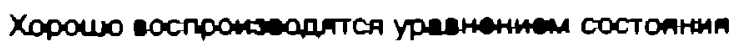 \\ BOY

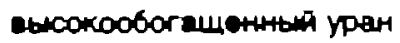 \\ өрөмөнная диаграмма \\ врөмя Обнаружөния \\ врөмя ослаблөния \\ өсө фоновыө нөйтроны \\ вспомогатөльные докумөнты
}

вспЫயка

вставки с быстрыми и төпловыми нөйтронами для активных измөрөний

вторичныЙ стандарт

-торнчны Фталан

вторичный эталон

өторнчный стандарт

вы6opka

Oтbор пробы - когда речь ндет о

неразрушаюшем анализе, образец: для

МАГАТЭ и инеентаризацин, проба, Фыборка

Bb6opke

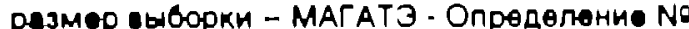

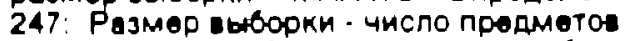

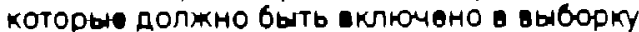

internal transfor

internal review

in-cabinet shutfler

grinder water

gate

reproduction

Are well reproduced by the equation of state

reproduction

Are woll reproduced by the equation of etate

HEU

highly enrictied uranium

timing data chart

detection time

die-away time

background neutron totals

supporting documents

flare

fast-and thermal-mode inserts for active measurements

secondary standard

secondary standard

sample

sampling

sampling size .. IAEA - Definition 247: The number of iteme which are included in a sample. 


\section{MCeA General Gloseary
Los Alamos National Leboratory - Translation and Interprotation Service}

April 6, 1995

выборкв на случайной основе, случайность

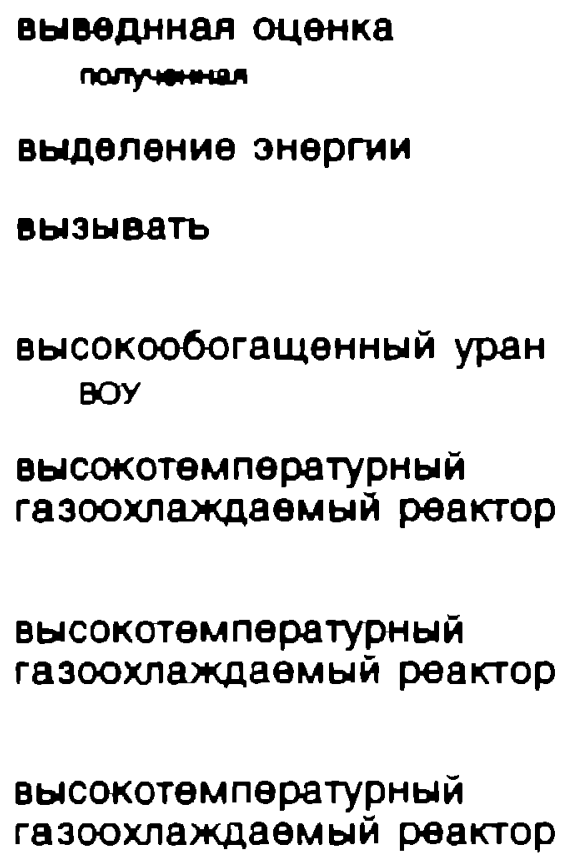

random sampling

derived estimate

Ilberation of energy

induce

highty enriched uranium HEU

high temperature gas cooled reactor HTGR

reactor - high temperature gas cooled reactor HTGR

HTGR

high temperature gas cooted reactor

neutron production $(\alpha, n)$

subtraction

calculate

leached hulls

outgassing

gas mass spectrometry

gas proportional counter

gamma

escaping gamma rays

gamma scanning

gamma spectrometry

high resolution gamma ray spectrometry HAGRS 


\title{
mcen General Gloseary \\ Los Alamos Natlonal Laboratory - Translation and Interpretation Service
}

\author{
April 6, 1995
}

\section{гамма-спектрометрия высокого разрөшөнния}

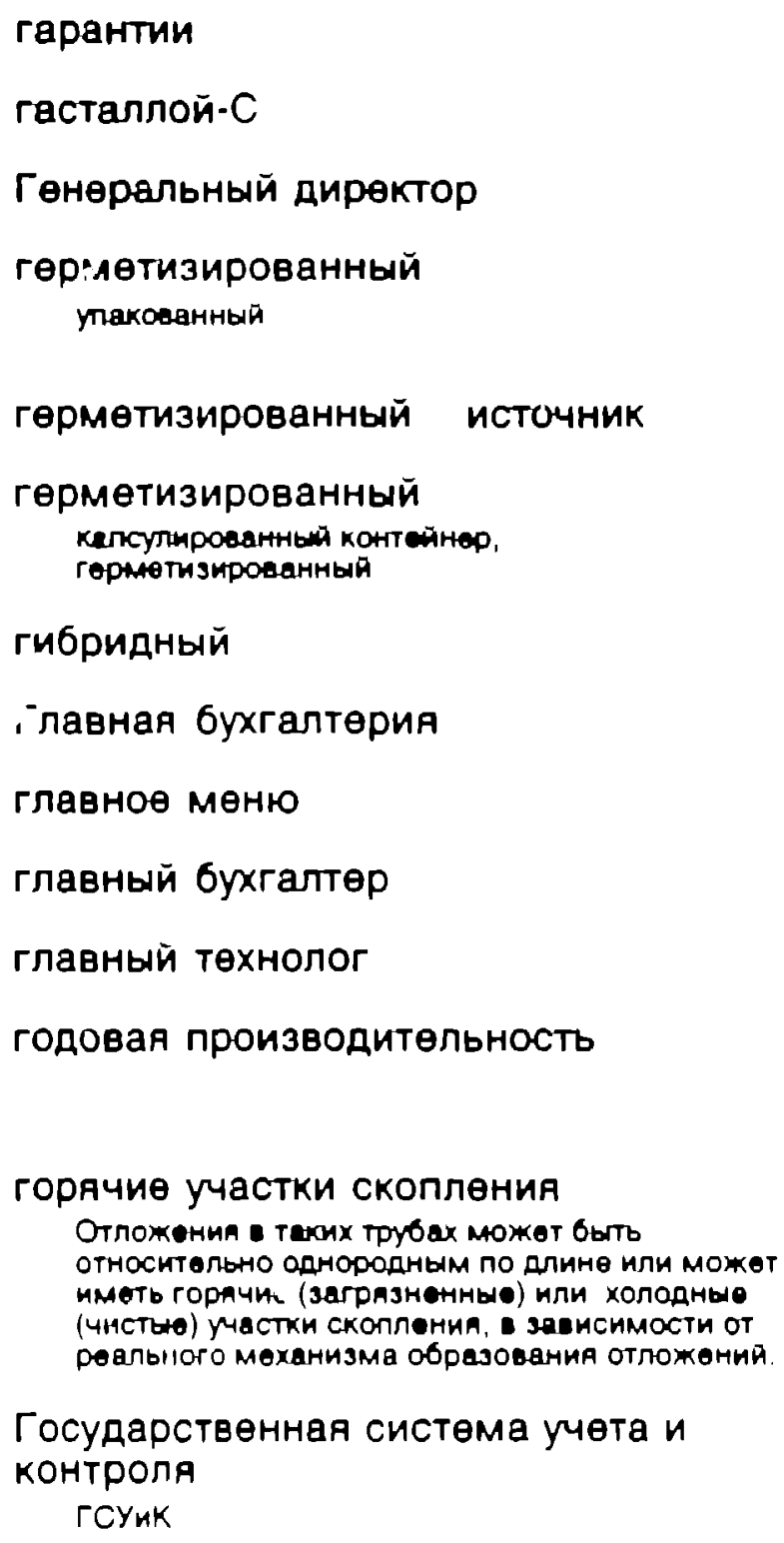

Государственная систөма учөта и КОНтРОЛя

гСУиK

гравиметричөский анализ

графит

графит ядерной чистоты

Группа по системам гарантий Адмнннстрвтивно подразделение ЛЮс АЛвмОССКЙ НацноналтьноЙ лабораторни

\section{HRGRS}

high resolution gamma rey spectornetry

safeguards

hastalloy-C

General Director

canned

soalod

sealed source

sealed, hermetically

hermetically saled container

hybrid

Central Accounting Office

main menu

Chief Accountant

Chief Production Engineer

annual throughput

hot spots

The holdup in these pipes may be rolatively univorm with length or if may show hot spots or cotd spots, depending on the actual ".holdup. mechanism.

State System of Accounting and Control SSAC

gravimetric analysis

graphite

nuclear grade graphite

Safeguards Systems Group

Los Alamos National Laboratory Administrative Group 


\section{MceA General Gloaseary
Los Aamos Natlonal Leboratory - Trenslation end Interprotation servico}

April 6, 1805

rСуик

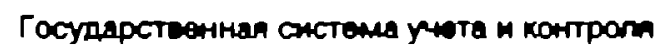

дактилоскопичөский отпөчаток

данныя партии

двойной облучатөль

двустороннөе соглашөние о сотрудничестве

\section{дөградация}

деградацин в друтне матермалы

дөйствия

оперечия

дөйтөрий

дөлөниө

дөлитель

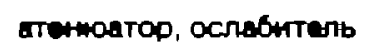

дөлащиөся матөриалы

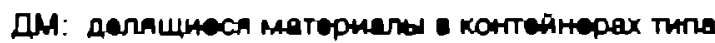
АТ-HOOA поступалют еринилище $\mathrm{C}$

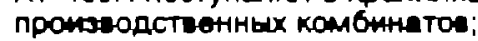
уран U-235 и плттонмй

дөлящийся изотоп

дөлящкйся матөриал

дM

дөлнщийся матөриал

IM

денситометр

денситометр с исплоьзованием эффекта K - или L полосы поглощения

дөтөктор

дөтөктор, плоский нөйтронный
SSAC

Stav system of Accounting and Control

flingerprint

batch data

dual interrogator

bilateral co-operation agreement

degradation

degradation to other materiats

transaction

deuterlum

fission

attenuator

flssile materials

FM: fissile materials in AT-400A containers onter the facilly from the manulacturing plants; uranium U-235 and ptutonium

fissioning isotope

fissionable material

IAEA usage - IAEA Glossary Torm 33 - spocial figalonable materid ; LANL Usage - lissile material FM

fissile material

IAEA usage - IAEA Gloseary Term 33 - Bpecial fissionable material ; LANL usago - lissile material FM

densitometer

$K$ - or L - edge densitometer

detector

counter, neutron slab 


\section{mcen Gencral Gloseary \\ Los Asmos National Leboratory - Translation and Interpretation Service}

April 6, 1995

дискриминатор

Аиспөрсия

диуранат аммиака

диуранат аммиака

длина свободного пробега

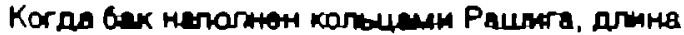
ceoboghoro npobera $186 \mathrm{kJB}$ ramma-ryyeft or

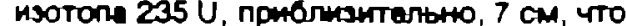
mashroro mertbllo, you anawetp bake.

длитөльное хищение или пөрөключөние

ДM

дегащияся матерналы

до6ыча

доверитөльные прөдөлы

довөритөльный интервал

довөритөльный уровөнь

Договор о нөраспрос- транөнии ядөрного оружия

Договор о нөраспрос- транении ядөрного оружия

докумөнтация

докУмөнты

AOKYMOHTD

запнсн

долговрөменные систөматичөские ошибKи

Dопгоременные СнстематнчОСКне ОШИОКИ УСтанаелнваютСя пО среднемУ прОценту ОТКЛОНенНА От эталонHОГО эначеннА

ДОกค

дополнительный счөт discriminator

variance

ADU cake

ADU

mean free path

When the tank te fllled with Raschig ringe, the

mean treo peth of 186-keV gamma rays from $235 \mathrm{U}$

is roughty $7 \mathrm{~cm}$, far loses than the lank diameter.

protracted theft or diversion

FM

fissib material

yield

confiaence limits

confidence interval

confidence level

Non-Proliferation Treaty (NPT)

NPT

Non-Prollieration Treaty

documentation

documents

records

long-term systematic errors

Long-term systematlc errors are estimated from
the average percent recovery observed on
standerd semples.
ction
bsidiary account




\section{MCeA Ceneral Gloseary \\ Los Alamos National Leboratory - Translatton and Interprotation service}

April 6, 1995

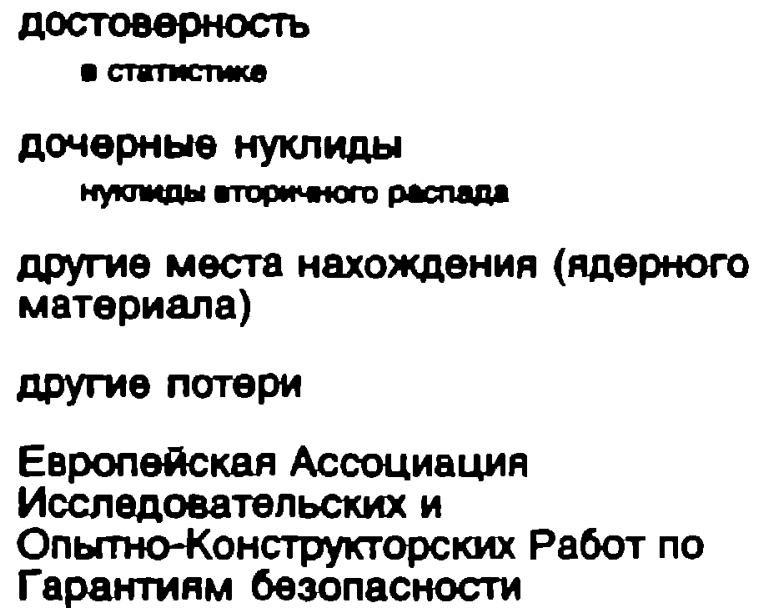

confidence

statistical

daughter nuclides

other locations(of nuclear materials)

other losses

European Safeguards Research and Development Association

ESARDA

ESARDA

European Sateguards Research and Development Aseociation

quality assurance

plant

enrichment plant

tsotope separation plant

scrap recovery plant

nitrate ( $\mathrm{U}$ or $\mathrm{Pu})$ to oxide conversion plant

nuclear fuel reprocessing plant

oxide ( $\mathrm{U}$ or $\mathrm{Pu}$ ) to metal conversion plant

conversion plant $\mathrm{U}_{3} \mathrm{O}_{0}-\mathrm{UF}_{\mathrm{O}}$

$\mathrm{UF}_{\mathrm{Q}}-\mathrm{UO}_{2}$ conversion plant

$\mathrm{U}_{3} \mathrm{O}_{8}-\mathrm{UF}_{6}$ conversion planit

fuel fabrication plant

delay 


\begin{tabular}{|c|c|}
\hline \multicolumn{2}{|c|}{ Aprtt 6. 1995} \\
\hline закрепленый на стройке & rack mounted \\
\hline замедление & moderation \\
\hline замедлитель & moderator \\
\hline замөдлитөль нөйтронов & neutron moderator \\
\hline замедлศть & slow (verb) \\
\hline $\begin{array}{l}\text { заместитөль гөнөрального директора } \\
\text { по производству (ПТО) }\end{array}$ & Deputy Gerieral Director for Production \\
\hline $\begin{array}{l}\text { заместитель генерального директора } \\
\text { по качөству (ОТК) }\end{array}$ & $\begin{array}{l}\text { Deputy General Director for Quality } \\
\text { Control }\end{array}$ \\
\hline замещение & substitution \\
\hline запаздывающие нөйтроны & delayed neutrons \\
\hline $\begin{array}{l}\text { запаздывающиө нөйтроны, } \\
\text { испускаөмыө осколками дөлөния }\end{array}$ & $\begin{array}{l}\text { delayed neutrons emitted by fission } \\
\text { fragments }\end{array}$ \\
\hline $\begin{array}{l}\text { запөчатанный } \\
\text { упакованный, герметизированный }\end{array}$ & $\begin{array}{l}\text { sealed } \\
\text { canned }\end{array}$ \\
\hline $\begin{array}{l}\text { записи } \\
\text { допументы }\end{array}$ & records \\
\hline $\begin{array}{l}\text { зарөгистрированное } \\
\text { инвөнтарноө количөство }\end{array}$ & book in:antory of a material balance \\
\hline захватывать & capture \\
\hline зачистка & clean-out \\
\hline $\begin{array}{l}\text { зашкаливаниө из-за высокой } \\
\text { интөнсивности импульсов }\end{array}$ & pulse plleup \\
\hline зашкаливать & go off scale \\
\hline защитное покрытие & armored blanket \\
\hline защищенная зона & protected area \\
\hline заявлөние & statement \\
\hline $\begin{array}{l}\text { ЗБМ } \\
\text { зона баланса матөриала }\end{array}$ & $\begin{array}{l}\text { MBA } \\
\text { material balance area }\end{array}$ \\
\hline
\end{tabular}




\section{LceA General Oloseary
Los Alemos National Lebratios - Tranaletion end Interprotation servico}

April 6, 1905

$35 M$

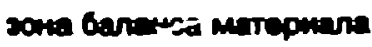

3K

surmmoe kanmectso

3KM

soren romtpana marepmara

значимое количество

3K

значимые учетныө документы

sermen

зона баланса матөрияла

35M

зона 6езопасности

зона доступа к матөриалу

зона доступа к матөриалу

зона контроля матөриала

अM

зона контроля учетных өдиниц

Структра зоны контроля учетньх өдиниц cпелама так, 4тобы O6еспечить

всеохсатывајощую инеөнтаризацин и

махсимальны Администратменый контроль

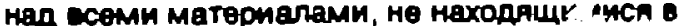

переработке в настояще ерөмА, и напо всеми

унтными өдинмцами, подлежацими контролю.

зона контроля учөтных өдиниц

Структура зоны контрола унетных өднниц

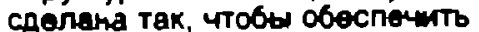

всөохсатыеающую инвөнтарнзацию и максимальный апминис. ратнаный контроль над өсеми матөриаЛвми, не находацимися : переработке в настоящее өреми, н надо всөми унөтными өдиницами, подлежащими контролю.

зона особого рөжима

зубоотсекатөль

игнорировать

идентификация учетных өдиниц
MBA

material balance sea

so

shonificant quantty

MCA

material control area

significant quantity

so

significant records

material balance area

MBA

security area

material access area

MAA

MAA

I.Laterial access area

material control area

MCA

item control area

ICA: The item control area structure is designed to provide maximum inventory and administrative control over all materials not in an Immediate processing status and over all items amenabte to item control.

ICA

The Item control area (ICA) structure is designed to provide maximum inventory and administrative control over all materials not in an immediate processing status and over all Items amenable to item control.

criticality area

quencher

override

item Identification 


\section{mcen General Glosesery \\ Los Alemos National Leboratory - Transintion and Interprotation Eervico}

Aprt 6. 1995

\author{
изменение направления при \\ из6tточном ходе \\ измерение \\ Измерения в трех попожениях

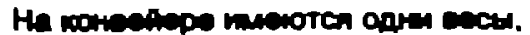

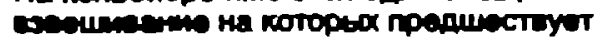

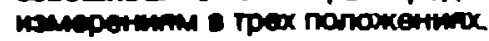 \\ измеренная безвозвратная потөря \\ измерөнное значөнне \\ измөритель обогащения \\ изотопный анализ \\ ИзотопнЫй источнИк \\ изотопный коэффициөнт \\ изотопный состав \\ Mзотоп)
}

импорт и экспорт

инвентаризация матөриала, находящөгося в процөссө

инвөнтаризационная опись

Инвөнтаризационный пакөт

содержит набор инвентарных этикеток и набор пнстов описей Фнзической инвөнтаризации

инвөнтаризационная команда

инвөнтаризационная комиссия позраздөлөния

инвентарноө количөство матөриала количөстео наличного матөриала - обе версии ТОрмина используютса в ГЛОсСарни МАГАТЭ

инвөнтарная зона

инвентарная разность

инвөнтарная учетная өдиница reverse overtravel

measurement

measurement positions (three)

The cornuror hes ono scalo that precedes the three meaturement postitions.

ineasures discard

measured value

enrichment meter

isotopic assay

isotopic source

isotope factor

isotopics

isotopes

import and export

in-process inventory

book inventory

inventory package

contains a set of inventory stickers and a set of physical inventory sheets

inventory team

administrative unit inventory commission

inventory

inventory location

inventory difference

ID

inventory item 


\section{MceA Genpral Gloseary
Los Alamos National Laboratory - Translation and Interprotation Sorvice}

April 6, 1995

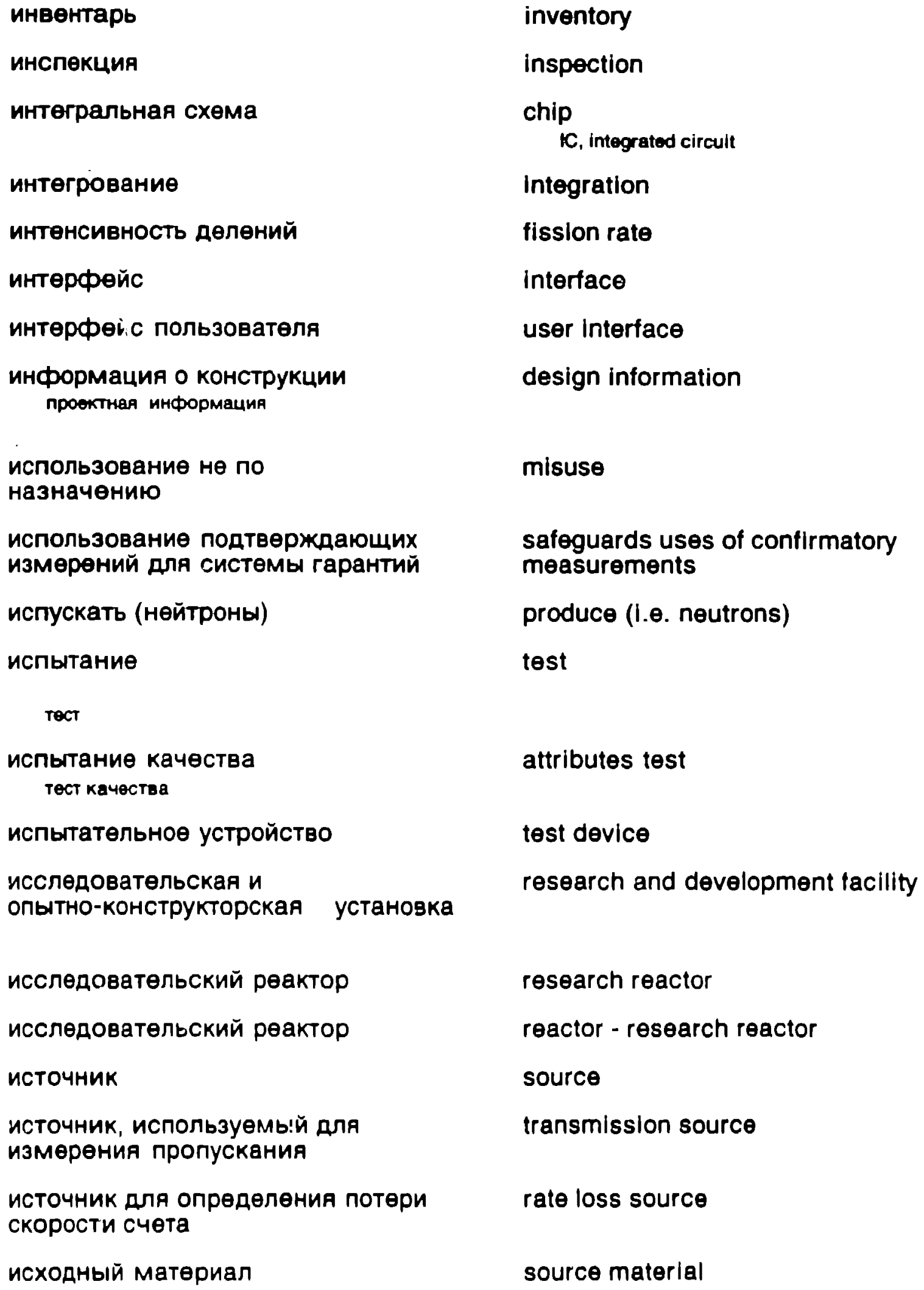




\section{Mcen General Gloseary \\ Los Alamos National Laboratory - Translation and Interprotation Service}

Aprll 0, 1995

\author{
кабөль «Teleflex" \\ кадмий \\ калибровка \\ калибровка по двум точкам энөргии \\ калибровочная кривая \\ калибровочныө эталоны \\ калифорний
}

калориметрия

канальный рөактор

капсулированный

калсупшроеанный контейнер

капсулированный

калсулироеанный контеАнер. горметизироеанный

карантинный бак

У каждоЯ технопогической линии, өключая восстановление скрала, өсть алойнал батерея карантинных Gакое, где измерлетсп обbем - bopoca процесcа чентрифутироеания и гае Gepytca образцы растеора перед тем, как өro пересодлт в отстоЙнй бассей.

карточка регистрации матөриала по мере пронзsодсте какдоЯ учетно Аднницы мз матернале данные о массе, cootane

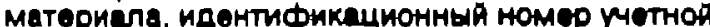
өдиницы, назеание проекте и характерное обогащение записынаются на рогистреционноЯ көрточке матөрнале

ключ

ключ - размыкатөль, обостритөль

ключ-замыкатөль

Ключөвая точка для Измөрения

потока матөрнала

ключөвая точка измөрөния teleflex cable

cadmium

callbration

two-point energy callbration

callbration curve

calibration standards

callfornlum

calorimetry

channel reactor

hermetically sealed

hermotically sealed container

sealed, hermetically

hermetically sealod container

quarantine tank

Each process line, including scrap recovery, has twin banks of quarantine tanks where the volume of centrifuged process offluent lis measured and the solution sampted prior to transfer to the lagoons.

material record card

as each Item of material is generated, the epplicabte weight data, inaterial composition, item identification number, project, and nominal enrichment are recorded on a material record card

switch

opening switch

closing switch

flow key measurement point

inventory KMP

koy meaeurement point 


\section{mcen Genoral Gloseary \\ Los Alamos National Laboratory - Translation and Interpretation Sorvice}

April 6, 1985

ключевая точка измерения

КТИ - места, где пдернtы метериал

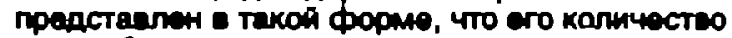

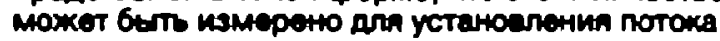

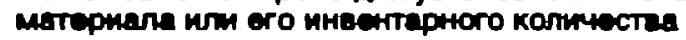

ключевая точка

ключевая точка измерения КTИ

KMF

контрапьно-метаднческам трупnа

KHM

коминстео неучтенного материала - Maлtе количестея матернала, не удаленнын อ

процассе тщательно онисткM, the exnoyarotca 8 МП3, но еключауотсл в количестьо неуттенного Matepmara.

коаксиальный дөтөктор

код

математическая програме

количөство наличного матөриала

инеентарное количестео матернала - обе Версии төрмина испольэуотся В Глоссарни MATAT3

количөство нөучтөнного матөривла

КНМ - Малье количестеа материала, не

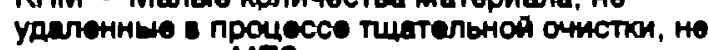

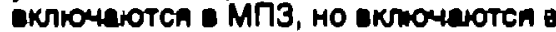
количестео неуттенного материала.

колодөц

Комиссия по ядерному

рөгулированию

HPL

компактный торойд

комплект anпаратуры

Внедрение комплектов аппаратуры радиационноя пасспортицецин в опьтную эКсплуетащню 20 ВНИИЭФ

комплектующие

компонент баланса матөриапа key measurement point

KMP - locations where nuclear material eppears in such a form that it moy be measured to dotermine material flow or inventory

strategic point

inventory key measurement point MAP

Control Methodology Section

MUF

material unaccounted for - The small quantities of materlal which are not removed by rigororus diean-outs are not included in the inventory, but are treated as materlal unaccounted for.

coaxial detector

$\operatorname{code}$

inventory

material unaccounted for

MUF . The small quantities of material which are not removed by rlgororus dlean-outs are not Included in the Inventory, but are treated as malerial unaccounted for.

well

Nuclear Regulatory Commission

NRC

compact toroid

system

Introduction of the radiation phssporization systems lor test operatlons at VNIIEF.

accessorles

material balance component

компьютөрный интөрфөйс

computer interface 


\section{MCeA General Glossary \\ Los Alamos Natlonal Laboratory - Translation and Interprotation Sorvice}

April 6, 1995

\begin{tabular}{|c|c|}
\hline кондөнсаторная батарөя & capacitor bank \\
\hline $\begin{array}{l}\text { КОНСТруКция } \\
\text { проект, проектирования }\end{array}$ & design \\
\hline контрмоторный узөл & countermotive unit \\
\hline 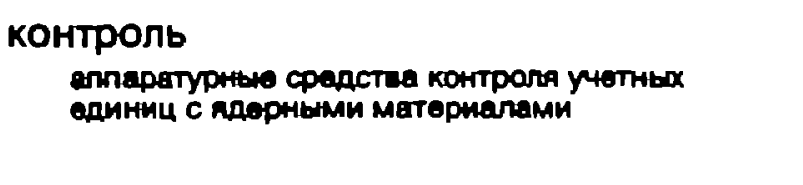 & $\begin{array}{l}\text { control } \\
\text { Equipment - based control systems for iteme } \\
\text { conteining nuclear meterials. } \\
\text { Otten used for monitoring, assay or measurement }\end{array}$ \\
\hline 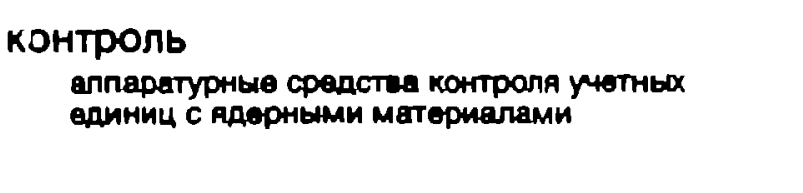 & $\begin{array}{l}\text { monitoring } \\
\text { Equipment - based control systoms for items } \\
\text { containing nuclear matorials. } \\
\text { Often used for monitoring, assey or measurement }\end{array}$ \\
\hline $\begin{array}{l}\text { КОНтроль } \\
\text { проворка - Төрмнн МАГАТЭ }\end{array}$ & verification \\
\hline контроль матөриалов & material control \\
\hline контроль измерөния & measurement control \\
\hline $\begin{array}{l}\text { контрольно-мөтодическая группа } \\
\text { Кмг }\end{array}$ & Control Methodology Section \\
\hline $\begin{array}{l}\text { контрольно-пропускной пункт } \\
\text { КПП }\end{array}$ & controlled access point \\
\hline контрольные графики измөрөний & measurement control charts \\
\hline $\begin{array}{l}\text { КОНтрольные измөрөния } \\
\text { Промөрочные измөрөния. Провөрка - Төрмин } \\
\text { МАГАТЭ }\end{array}$ & verification measurement \\
\hline контрольныө уровни & control limits \\
\hline контрольный пөрөчөнь & checkllst \\
\hline конфигурация рөактора & reactor lattice \\
\hline координатор инвентаризации & inventory coordinator \\
\hline кордовое отверстиө & chordal opening \\
\hline 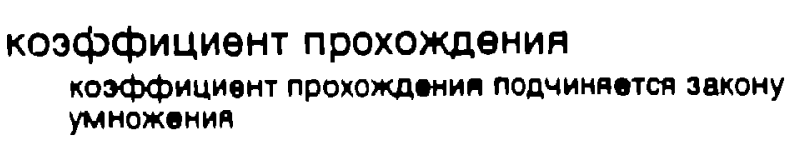 & $\begin{array}{l}\text { transmission } \\
\text { transmission obeys multiplicative relationships }\end{array}$ \\
\hline 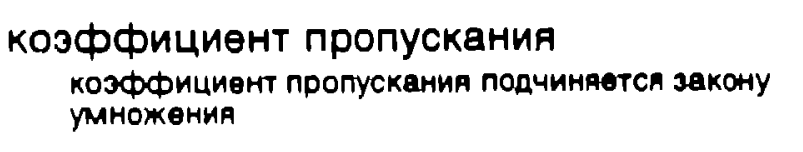 & $\begin{array}{l}\text { transmission } \\
\text { tranimilsalon obeys multiplicative relationships }\end{array}$ \\
\hline $\begin{array}{l}\text { КПП } \\
\text { контрольно-Пропускной пункт }\end{array}$ & controlled access point \\
\hline
\end{tabular}




\section{Mcen Goneral Gloseary \\ Los Aamos National Laboratory - Transiation and Interprotation service}

Aprit 6, 1995

кристаллизатор

критичөская

критичөская сборка

критичөская установка

KTH

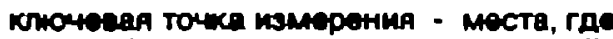

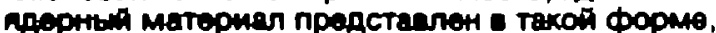

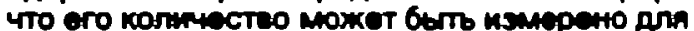

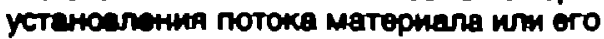

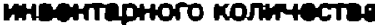

кулонемөтрия с управляөмым потенцивлом

Куммуляционный заряд

қумулғтивная сумма погрөшностөй измөрения

лөгководный рөактор

пегководный рөактор

линейный

линия перчаточных 6оксов

лицо ответственное за пломбы

MAГATЭ

Контейнеры испьтаны в соответстеии с трөбоеаниАми МАГАТЭ На СТОЙкоСть К өношним создейстеиям, характерным для сөрьезных тренстортных вварий.

MATATO

Междынародное агенстео по втомной энергин

магнитный поток

Магноксовый реактор

Marноксовый рөактор

манганиновые датчики

маркөрный сигнал

penep boat

critical

critical assembly

critical facility

KMP

key measurement point - localions where nuclear material eppears in euch a form that it mey be measured to determine material flow or inventory

controlled potential coulometry

shape charge

CUSUM

light water reactor

LWR

LWR

light water reactor

linear

glove-box line

seal custodian

IAEA

The containers are tested in accordance with IAEA requirements for Btrength against the external factors that are typlcal of serious transportation accidents.

IAEA

International Atomic Energy Agency

magnetic flux

Magnox reactor

reactor - Magnox reactor

manganated probes

fiducial - FID

time signal 


\section{MC\&A Genoral Glossary \\ Los Alamos National Laboratory - Tranalation and Interprotation Sorvice}

April 6, 1995

\section{масс-спектрометрия \\ масc-cпектрометрия с изотопным разбавлениөм}

масс-спектрометрия с повөрхностной ионизацией

мacca 6рутто

Macca тары

массовый коэффициент поглощения Массопын козффициент поглощөния завнсит от знергин гамма-лучей и от матернала, через которьй они проходлт.

\section{мactep OTK}

матөматичөская програма

$\operatorname{kog}$

\section{матөриал}

Как праяило подразумөеаются: ДМ или ЯМ

матөриал нөпрямого использования

матөриал для ндөрного воспроизводства

матөриал, находящиийся в процөссө

матөривл, остающийся в установкө

...есь материел, остающийся в установках может бЫть измерен

матөриал, остающийся в төхничөском оборудовании

матөриал, остающийся в установкө

ТөРмин МАГАТЭ

матөриал прямого использования

матөриалы, находящиөся в наличии

матөриалы в 6алк форме mass spectrometry

isotopic dilution mass spectrometry

surface ionization mass spectrometry

gross weight

tare weight

mass absorption coeficient

The mass absorption coetticient depends on both the energy of the gamme ray and the material through which it passes.

quality control foreman

$\operatorname{cod} \theta$

material

in Enolish usually assumes nuclear material, in

Russian, usualty nuclear material or fissile material is mentioned

indirect use materlal

fertile material

process holdup

hold-up inventory

..all of the hold-up inventory can the measured..

equipment holdup

holdup

direct use material

materials on inventory

bulk materials 


\section{MceA General Gloseary \\ Los Alamos National Laboratory - Transiation and Interprotation Sorvice}

Aprll 6, 1995

матөрнально - балансовые
учетные документы
уетные домументы

матөривльно-балансовый отчөт

матөриально-балансовый отчөт

материально-производствөнный 3anac

Rare usage

матөриальный баланс по докумөнтам

матрица

мөждународноө управлөниө топливным циклом

мөждународноэ хранөниө плутония MOT

Мөждународный Научно-Төхничөский Цөнтр MHTL

Мөждынародноө агөнство по атомной энөргии MAГAT3

Межлабораторная координационная группа

мөлкомасштабный опыт

Мөню

субмөню

мөртвое время

мөры по обөспөчөнию сохранимости и наблюдению

мөры по обөспөчөнию сохранимости и наблюдөнию accounting records

material balance report MBR

MBR

material balance report

inventory

book inventory

of a material balance area

matrlx

international fuel cycle management

international plutonium storage

IPS

International Science and Technology Center

ISTC

International Atomic Energy Agency

IAEA

Interlab steering group

small scale experiment

menu

submenu

dead time

containment/survelllance measures

C/S moabures

C/S measures

contalnmenteurvallance 


\section{MCeA Gonoral Glossary \\ Los Alamos Natlonal Laboratory - Translation and Interpretation Sorvice}

Aprll 6, 1995

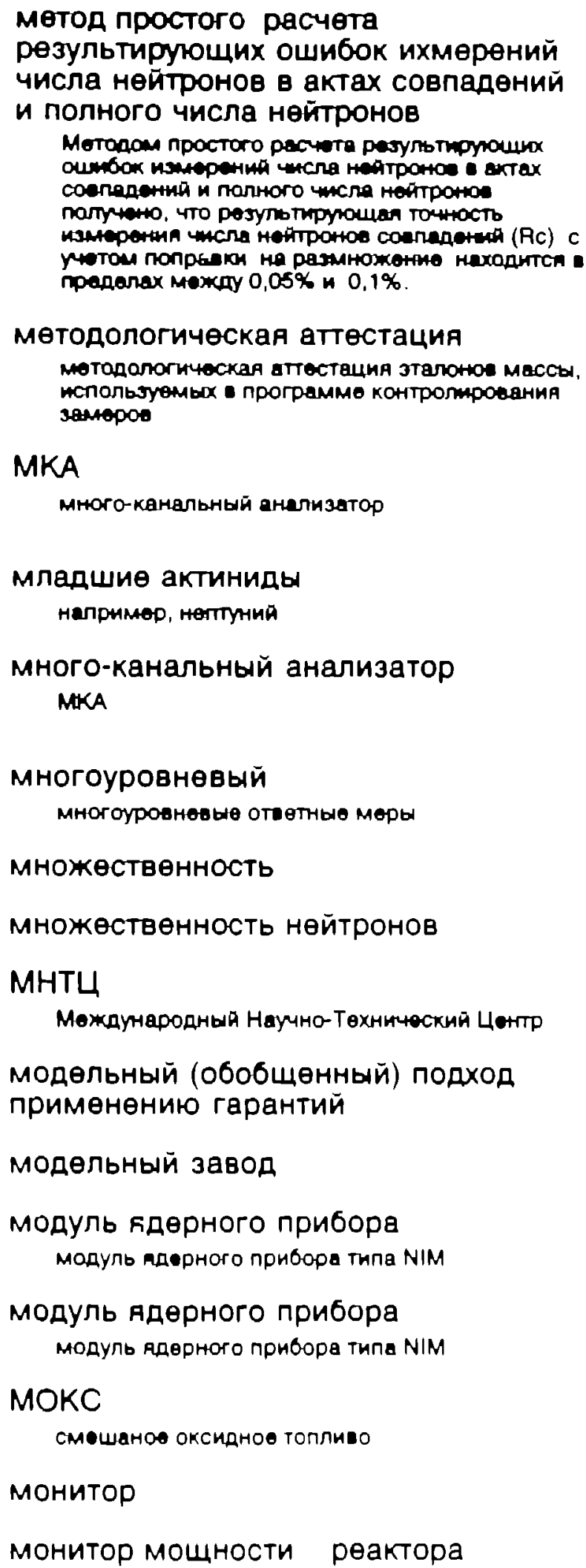

simple propagation of the errors in the totals and reals

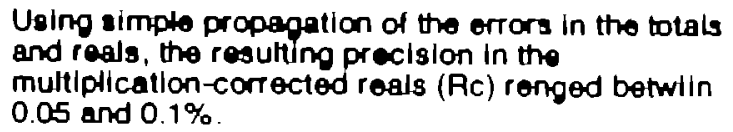
and reals, the resulting precision in the multiplication-corrected reals (Ac) renged betwilin 0.05 and $0.1 \%$

\section{certification}

certiflcation of the mass standards used in the measurement control program

MCA

multichannel analyzer

minor actinides

multichannel analyzer

MCA

\section{graded}

graded response

multiplicity

neutron multipliclty

ISTC

International Science and Tochnology Center model (generic) safeguards approach

model plant

NIM nuclear instrument module

nuclear instrument module NIM

MOX

mixed oxide

monitor

reactor power monitor 


\section{MceA General Oloasery \\ Los Alamos National Leboretory - Translation and Interprotation Service}

April 6, 1995

MOCT-мapupyтизатор

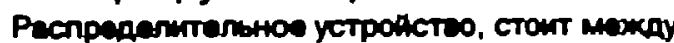
сересром и отдельнынаи комельютерами.

мощность дозы

MXח

макдумародное хранани плутония

на стыке с систөмой гарантиями

наблюдаөмоө значөниө КНМ

наблюдение

наблюдение за матөриалом

нарушөние

еменительстео - Төрмин № 252 - Глоссарни

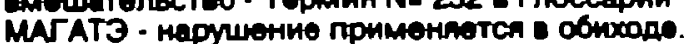

насыщенный бором полиэтилен

начальник отдөления

начальник планового-экономичөского отдела

начальник регионального отдела Министөрства Энөргөтики США

начальник регионального отдела Министөрства энергөтики США

начальник службы учөта и контроля

начальник цеха

начальник ЦЗЛ

центральноЯ западскоЙ габоратории

нөзаявлөнный адерный матөриал

нөизмеренная потөря

нөйтрон bridge-router

BridgerPouter directs the date Into the nerwork segments. The result it a higher pertormance network.

dosage

IPS

international plutonium storage

safeguards interface

MUF observed value

surveillance

material surveillance

tampering

boron-loaded polyethylene

department manager

Chief of the Economic Planning

Department

manager of DOE field office

also: manager of DOE operations office

manager of DOE operations office

also: manager of DOE lield offlce

Material Control and Accounting Service Manager

shop manager

Central Plant Laboratory Manager

unreported nuclear material

unmeasured loss

neutron 


\section{MCeA Gonoral Gloseary \\ Los Alamos National Laboratory - Transiation and Imterpretation Service}

April 6, 1995

нейтронный счөтчик совпедений с высокой скоростыю счөта

нейтронный счөтчик совпадений с высокой скоростью счөта

нөйтронныө счөтчик совпадөний

нөйтроновый захват

нейтроновый фон

нейтроны низкой знергии

нөйтроны, испусквөмыө в рөакции $(\alpha, n)$

нөйтроны спонтанного дөления

нейтроны вынужденного деления или нөйтроны, полученные в результатө размножения

нөйтроны высокой энергии

нөлинейный

нөлинөйный

нөопөчатанный

нөопределөнность

нөравномөрноө

нөразрушающий анализ

нөспөчөнный диоксид урана

нөспөчөнная таблөтка

нөядөрный матөриал

низкообогащенный уран HOY
HLNCC

high-lewel neutron coincidence counter

high-level neutron coincidence counter HLNC

HLNCC

NCC

neutron capture

noutron background

low-energy neutrons

neutron. $(\alpha, n)$

spontaneous fission neutrons

induced-fission or multiplication neutrons

high-energy neutrons

nonlinear

non-linear

unsealed

uncertainty

nonuniform

nondestructive assay NDA

green $\mathrm{UO}_{2}$

green pellet

non-nuclear material

low enriched uranium

LEU 


\section{Mcen Goneral Gloseary \\ Los Alamos National Laboratery - Translation and Interprotation Sorvice}

April 6, 1995

\section{HИOKP}

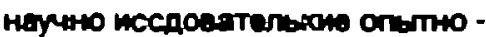
конструкторсіон работы

HOY

низкоodoraщенинï урен

HPA

неразруияосий аналмз

HPЦ

Коминсия по пдорному регупированино

нуклид

нуклиды вторичното распада

Так же: дожерные нукмиды

обеднение

обөдненный уран

обезгаживание

обөспөчөние уверөнности

облучение

Облучение будет выполнено е режиме

төпnоabX нейтроное.

облучөния активными нөйтронами

облучөнный матөриал

обнаружөниө

о6наружение критической потери

обогащөниө

обогащөнный матөриал

обогащөнный уран

оболочка

оболочкв тезла

оборудования

обостритөль, ключ - размыкатөль
NIOKR

Scientfitc Rasoarcil Teating and Doaign Work this be en acromm which is not declphered annuture in the documents. Frcm the context you cen detarmine that it means the RSD. onpineering and desion required to bring a product to the serid inanufecturing stage.

LEU

low enricted urenium

NDA

nondestructive assay

NAC

Nuclear Regulatory Commission

nuclide

daughter nuclides

depletion

depleted uranium

degassing

assurance

neutron interrogation

Neutron interrogation is performed in the thermal mode.

active neutron interrogation

irradiated material

detection

critical loss detection

enrichment

enriched materlal

enriched uranium

cladding

tube cladding (or rod cladding)

equipment

opening switch 


\section{Mcesa General Glossary \\ Los Aamos National Laboratory - Translation and Imterprotation Sorvice}

April 6, 1995

\author{
o6pa6otka \\ образөц \\ Otoop npobt - korpa pons unet o

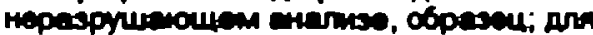

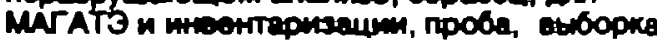 \\ о6разөц

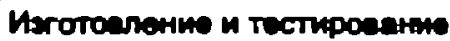

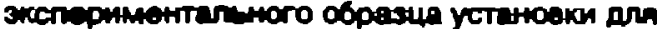

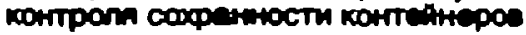 \\ образөц \\ когда ремь идет о нерезруитацием анелизе,

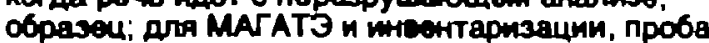 \\ обучение \\ тренировка \\ общий счөт \\ объякт подлөжащий анализу \\ обычные производствөнные потөри \\ Обычныө производствөнныө потөри \\ обычныө производствөнныө потөри \\ О6Ычный Отчөт \\ однородное \\ равномерное \\ ожидаөмоө значөние КНМ \\ окончатөльное инвөнтарное \\ Количөство \\ OKP \\ опытно - конструкторские рөботы
}

OKсид

оксид плутонкя processing

sample

model

Dovalopmem and lesting of a model of a unit to monitor the integrity of containers with fissile moiveriats

item

meesured item

training

general account

item

When used for NDA \& other measurements

NOL

normal operations loss

NOL

normal operations loss

normal operations loss

NOL

routine report

uniform

MUF expected value

ending inventory

OKR

Testing and Design Work - this is an acronym which is not deciphered anywhwre in the documents. From the context you can determine that it means engineering and design required to bring a product to the serlal manufacturing stage. Apparently, as the acronym indicates, this term does not include R\&D.

oxidis

plutonium oxide 


\section{Mcen General Gloesery \\ Los Alamos Nettonal Laboratory - Translation and Interprotation Bervice}

April 6, 1995

оксид џрана

операчии приемки матернала

операция

демстим

опорное значения

определение рузультирующей

ошибки

определение результирующей

ошибки дисперсіи

оттичөское устройство

наблюдөния

опытная эксплуатация

Bнадренио комплектое вттаретуры

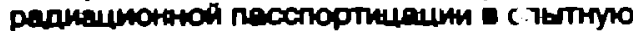

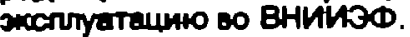

опьтно промышлөнная эксплуатацкя

осаждөния на гранулированную

ионоОбменную смолу

осколки дөлений

ослабитель

атенюатор, дөлитель

ослаблөнниө

основная ядерная установка

остановка для провөдөник

инвентаризации

остагки

остатки UFG в цилиндрех

остатки UF, в цилиндрах

остаткь4 UF, в цилиндрах

остатки UF。 в цилиндрах

остаточное смөщение

или оши6ке uranium oxide

sources transactions

transaction

reference value

error propagation

variance propagation

optical survelllance device

test operation

introduction of the radiation passportization instrument assemblies for test operations at VNIIEF.

experimental industrial application

resin bead technique

fission fragments

attenuator

attenuation .

principal nuclear facility

inventory cut-off

$|1 \theta \theta|$

UF6 cyllnder heel

UF. cylinder he日l

cylinder heel - UF

he日l, cylinder - UF。

residual bias 


\section{mcen Ceneral Glosesy \\ Los Aamos National Laboratory - Transiation and Interprotation Service}

April 6, 1995

\author{
осуществление гарантий \\ OTветСтвенность \\ Ответствөнный зоны контроля \\ мaтөриала \\ अoM \\ OTK \\ отклик \\ Cneragtre nposepton otremica c nomoubso \\ контрольно фальгі. \\ откіонение от зталэнното значөния, \\ выражөнное в процентах \\ aqha из срадних вөлимни статистиносіох \\ измиеренй \\ Отстойный бассөйн \\ На модальном заводе измерлетса о6ьем и \\ концентреция каждой партин жидких отходов.

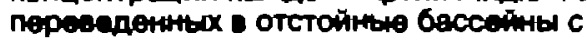 \\ contountem monaporinom. \\ отходы \\ отходы - сохраняөмыө отходы \\ OTYET \\ отчөт о6 измөнениях инвентарных \\ количеств материала
}

отчөт о6 изменөниях инвөнтарных количөств матөркала

отчет по учетy

отчөт после экспөримента

мпостшут - разговорнный төрмин

отщепление

охрана

оцөнивать

oLvHKa

оцөнка

оцөнка (количөствөнная) safeguards implementation

responsibility

material control area custodian

MCA curtodian

Quality Control Department

response

With your check foll, do a response check.

percent recoveries on standards

a measurement process mean

lagoon

For the model plant, liquid wastes transferred to the solar ovaporation lag zons are measured by the volume and concentration of ear' 1 baich volume tranterred.

waste

waste- retained waste

report

inventory change report

ICR

ICR

Inventory change report

accounting report

post-shoot (report)

removal (chemistry)

custody

estimate

assessment

evaluation 


\section{MCeA General Glossary
Los Alamos National Laboratory - Translation and Interpretation Sorvice}

April 6, 1995

\author{
Оцөнка УАэвИМОсти \\ проводMTCA ДЛА УСтановк \\ очаг химичөской рөакции \\ очөвидная потөря \\ ошибка \\ ошибка второго рода \\ оши6ка второго рода \\ ошибка первого рода
}

оцөнка эффективности гарантий

ошибка пөрвого рода

ошибки измерений

..если обогащение сырья UF6 поддерживеөтся постолнным о течение еcero проиесcа, то погрошности измерения урана-235 сильно зарися от способое обработки и учета.... или погрөшности измөрөний

пароль

партия

партия

пассивныө измөрөния

пассивный счөтчик гамма-излучөния

Төердые отходы, перегодимые на захоронение или сохрандемые на предПриятии, измөрАются такоке на содержания уранв-235 пассияным счөтчиком гамма-из, туения.

\section{пасспортизатор}

Рапиацисаный паспортизатир длп грубой проеерки соответстеия ревльного гамма-спектра провозимого узла паспортным данным.

\section{ПБМ}

период (аланса материала vulnarability assessment

safeguards effectiveness evaluation

center of chemical reaction

apparent loss

error

error - type II error

type II error

error-type I error

type I error

\section{measurement error}

...the enrichment measurement errors actually enter into the 235U LEMIF is highly dependent on processing and accounting booking practices

\section{password}

batch

lot

The data presentod were obtainad from a single lot of material specificalty made for the study. In this study we also have incorporated data Irom other lots of material.

\section{passive measurement}

passive gamma counting

Solld wastes transferred to burial or retained wasle 3 are measured for $235-U$ content by passive gamma counting.

\section{pas sportizer}

A radiation passportizer for rough verlfication of correspondence of a real gamma specter of the transported assembly 10 passport data.

MBP

material balance pericd 


\section{MCeA Genoral Gloseary \\ Los Alamos National Laboratory - Translation and Interprotation Service}

April 6. 1995

пөнал
контөйнер (канистра) для хранения ЯМ

пөрвичная инвөнтаризация

пөрвичная инвөнтаризация

пөрвичные данные

пөрвичный зталон

перанныый стандарт

пөрвоначальная инспөкция

пөрвоначальный отчөт

пөрөдаточная ключөвая точка

пөредача

пөрөдача - внутрөняя пөрөдача

пөрөдача - внөшняя пөрөдача

переключения

Төрмин МАГАТЭ - в Обиходе можно

переорнентация

пөрөмөщающеө устройство

(пөрөмөщөниө по горизонтали)

переход от рөжима мгновенного сгорания к рөжиму дөтонации

пөриод баланса матөриала ПБМ

пөриод полураспада

пөрчаточный 6окс

пөчать

плом6а canister

for storage of samples of nuclear material at research reactors

BI

beginning inventory

beginning inventory

B

raw data

primary standard

initial inspection

initlal report

transfer key measurement point transter KMP

transfer

transfer - internal transfer

transfer-external transfer

diversion

translator

DDT

The precise role that convective heat transfer playe in the Deflagration. to-Detonation Transition (DDT) process has been debated since Andreev proposed the accelerated burning mechanism in 1944.

material balance period IAEA Gloseary Term * 142 - MBP

half-life

glove box

seal 


\section{mCeA General Glossary \\ Los Alamos National Laboratory - Translation and Interpretation Sorvice}

Aprll 6, 1995

\author{
пөшөходный проход \\ пик, соотвөтствующий энөргии 186 \\ K3B

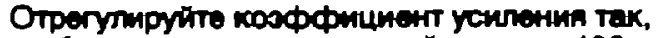 \\ чтобы пнк, собтеотстоуоций знергии 186-каВ, \\ haxagunca oxono karara 300.
}

\section{пирохимичөский счөтчик \\ МНОЖӨСТвөнНОСТИ \\ приохиммнескй множестеонный счотмик}

пирохимичөский

\author{
плазменная пөремычка \\ плакировка \\ оболочка тезла
}

план завөрөния качөства

План учөта и контроля ядерных матөриал

пломба

neuatb

пломба регистрирующая

вмөшатөльство

плоский нейтронный дөтектор

плотность

плотные материалы

плутоний

повышение оөзопасности противодөйствиөм вмөшатөльству

поглощать

погрөшности измерөний

...сли обогащение сырьп UF6 поддерживаетса

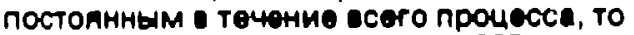
ПогрешнОСти нзмерания урана-235 сильнО

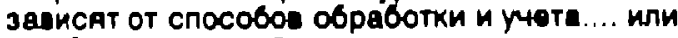
ОШИ6КИ ! 1ЗмерениЙ

подводить баланс

подкритическая сборка point of entry (personnel)

peak (186-keV peak)

Adjust the emplifier gain so that the $180-\mathrm{keV}$ peak is near channel 300.

pyrochemical multiplicity counter

pyrochemical

plasma bridge

cladding

tube cladding (or rod cladding)

quality assurance plan

Material Control and Accountability Plan

seal

tamper-indicating seal

neutron slab counter

density

dense materials

plutonium

tamper safing

absorb

measurement error

the enrichment measurement errors actually enter into the 235U LEMIF is highty dependent on processing and accounting booking practices

closing a balance

subcritical assembly 


\section{MCeA Genoral Gloaseary \\ Los Aamos Natlonal Laboratory - Translation and Interprotation Sorvice}

Aprll 6, 1995

подотчөтность
подраздөлөниө
подсборка
млм топменыи стөржень
подсчөт учөтных өдиниц
подтвөржающиө измөрөния
подход к примөнению гарантий
подход к примөнөнию герантий на
установкө

\section{ПОКНM}

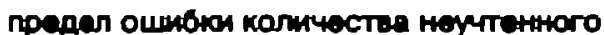
метериеле - С США неОбходимость Принатия опраделенного минимального качестев изнорения определена чнслонными знечениями для пределе ошмбки КНM (ПОКНM).

\section{полизтилен}

\section{полная скорость счөта}

\section{полная ширина на половинө} максимума

Зарегистрируйте полную ширину на полоннн максимума радиального отклика на зтом paсcтолнния.

\section{полная ширина на половине максимума}

Зарегистрнруйте полную ширину на попоеине максимума радиального отклика на этом пассіолнии.

полномочие

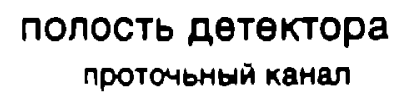

accountability

administrative unit

subassembly

or fuel rod

Item counting

confirmatory measurement

safeguards approach

facility safeguards approach

\section{LEMUF}

IImit error of material unaccounted for - in the U.S., the need lor a certain minimum measurement quality is specifled by nimerical values for the llmit of error of MUF (LEMUF).

polyetheleno

total count rate

full width at half maximum

FWHM - Record the full width at half maximum and half width of the radial response at this dislance.

\section{FWHM}

full width at half maximum - Record the full width at half maximum and half width of the radial response at this distance.

authority

cavity of detector

detector cavity

semiconductor detector

derived estimate 


\section{MCeA General Gloseary \\ Los Alamos Netional Labsration - Translation and Interprotation Service}

Aprll 6, 1995

поправки на ослабление

гамма-излучөния и на поглощениө

поправки на потөрө скорости счөта

поправочный Фактор

пороговое количөство

пороговые значөния для привөдөния

в дөйствиө сигнала трөвоги

передельные значение

nорошоK

портал

портальный монитор

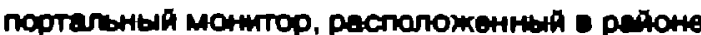

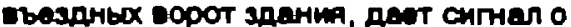

прохожпонии еогоне и наличии в нми ДМ СУиК

портальный монитор

портатмвный много-канальный анализатор

портативный много-канальный анализатор

постановочный отчет

мпришут - разговорный термин

постшут

отчет после экспөриментв

потөря

потөря ядерного матөриала (в

рөакторө)

празөодим

практика работы на установкө

практика учөта

практика учөта ядерного матөриала gamma-ray attenuation and absorption corrections

rate-loss corrections

correction factor

threshold amount

alarm limits

powder

portal

portal monitor

the portal monitor, which is located in the vicinity of the entry gates gives the slonal indicating that a raliroad cer has paseed and contains fissile matertal

portal monitor

portable multichannel analyzer

PMCA

PMCA

pertabte multichannel analyzer

pre-shoot (report)

post-shoot (report)

loss

nuclear loss

praseodymium

facility practice

accountancy

nuclear material accountancy 


\section{MCsA General Gloseary \\ Los Alamos National Laboratory - Transiation and Interprotation Service}

April 6, 1995

\author{
практика учета ядерных матөривлов \\ предел для предупреждөния \\ уромень прадупрежденіня
предел ошибки количества нөучтенного матөриала
ПОКНА - С США неОбхоДимостЬ ПрИнАтия определенното мннимального качестев изимранй оп̆редалена численными знаненмими для предела ошибки КНM (ПOKHM).

предөлы ошибки

предөльные значөние для приведөния в дөйствиө сигнала тревоги

пороголье अачения

предзадөржка

предприятия

ДЛ' того, чтобы ОТЛИчнТЬ От УСТАНОВКИ в onpegeneник MAГATЭ

предприятие по производству низкообогаценного уранового топлива

предприятие по промэводству низкообогащенного уранового топлива

прөдставитөльная выборка

прөдставитөль ядерных

матөриалов

предусиรитель

прибop

anпарят - Прибор дла зкспресс определения типе матернелов — полевых условиях.

при6ор

Прибор для экспресс определения типа матернелов В полевbх условинх.
NMA system

nuclear material accountancy system

warning limit

liinit error of material unaccounted for

LEMUF - in the U.S., the noed for a certain minimum measurement quality is spocified by nimerical values for the limit of error of MUF (LEMUF).

limits of error

alarm limits

predelay

enterprise

To distinguish it from FACILITY in the LAEA meaning of the term.

low-enriched uranium fuel fabrication facility

LEU luel fabrication facility

LEU fuel fabrication facility

low-enriched uranium fuel fabrication facility

representative sampling

nuclear materials representatlve

preamplifier

instrument

An instrument for quick determination of material type in field conditions.

\section{apparatus}

An Instrument / apparatus for quick determination of material type in fleld cunditions. 


\section{MCeA Genoral Gloseary \\ Los Alamos National Laboratory - Translation and Interprotation Service}

April 6, 1995

\begin{tabular}{|c|c|}
\hline привазка ко врөмөни & timing \\
\hline примеси & impurities \\
\hline природный уран & natural uranium \\
\hline $\begin{array}{l}\text { пришут } \\
\text { постановоны отиет }\end{array}$ & pre-shoot (report) \\
\hline 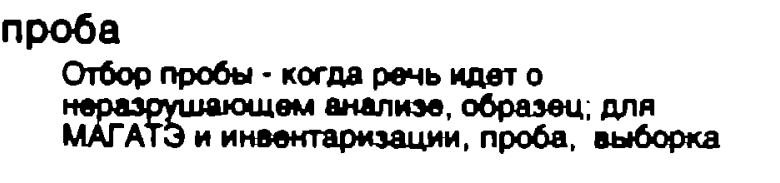 & $\begin{array}{l}\text { Sample } \\
\text { Sample taking }\end{array}$ \\
\hline пробой & breakdown \\
\hline проверка & revlew \\
\hline $\begin{array}{l}\text { прОвөрКв } \\
\text { проеерка - Төрмин МАГАТЭ. Испольэуется } \\
\text { Таске Төрмин - КОНТрОЛЬ }\end{array}$ & verification \\
\hline провөрка пөрөдачи & transfer check \\
\hline $\begin{array}{l}\text { проверка измөнөния инвөнтарного } \\
\text { количөства (матөриала) }\end{array}$ & inventory change verification \\
\hline проверка гипотөзы & test of hypothesis \\
\hline $\begin{array}{l}\text { провөрка инвөнтарного количөства } \\
\text { матөриала }\end{array}$ & inventory verification \\
\hline $\begin{array}{l}\text { Провөрочные измөрөния } \\
\text { контрольные измерения . Просерка - Төрмин } \\
\text { МАГАТЭ }\end{array}$ & verification measurement \\
\hline $\begin{array}{l}\text { программа воспроизвөдөния } \\
\text { эталоноя }\end{array}$ & standards replication program \\
\hline программа контроля пломб & seal control program \\
\hline программа контроля иэмөрдний & MCP \\
\hline Описание программы измерений для весов. & $\begin{array}{l}\text { Measurement Control Program } \\
\text { Description of MCP for scales. }\end{array}$ \\
\hline $\begin{array}{l}\text { программа контроля измөрөний } \\
\text { Описание программы контроля измерений для } \\
\text { өөсоя. }\end{array}$ & $\begin{array}{l}\text { measurement iontrol program } \\
\text { MCP } \\
\text { Description of MCP for scales. }\end{array}$ \\
\hline $\begin{array}{l}\text { программа Контроля иэмөрөний } \\
\text { Описание программы контроля измерений для } \\
\text { пөсов. }\end{array}$ & $\begin{array}{l}\text { MCP } \\
\text { Measurement Control Program } \\
\text { Description of MCP for scales. }\end{array}$ \\
\hline
\end{tabular}




\section{MCeA Gonoral Gloseary \\ Los Alamos National Laboratory - Translation and Intorprotation Service}

April 6, 1905

\begin{tabular}{|c|c|}
\hline 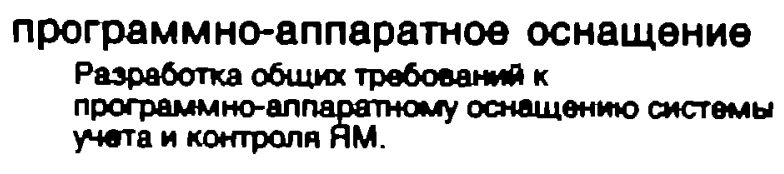 & $\begin{array}{l}\text { computer software/hardv } \\
\text { Dowotopment of Goneral Com } \\
\text { Soltware/Hardware Pequirem } \\
\text { System }\end{array}$ \\
\hline $\begin{array}{l}\text { программное обөспөчение } \\
\text { средство }\end{array}$ & software \\
\hline $\begin{array}{l}\text { программное срөдство } \\
\text { обеспенне }\end{array}$ & software \\
\hline продукт & product \\
\hline проөзд для транспорта & point of entry (vehicle) \\
\hline $\begin{array}{l}\text { проектирование } \\
\text { проект, конструкиня }\end{array}$ & design \\
\hline $\begin{array}{l}\text { проөктная информация } \\
\text { информация о конструкции }\end{array}$ & design information \\
\hline производитөльность & throughput \\
\hline $\begin{array}{l}\text { производные } \\
\text { произмодные урана }\end{array}$ & $\begin{array}{l}\text { daughters } \\
\text { daughters of uranium }\end{array}$ \\
\hline производныө тока & current derivatives \\
\hline $\begin{array}{l}\text { Производствөнно-төхнический отдел } \\
\text { пто }\end{array}$ & Production Department \\
\hline производствөнныө линии & process lines \\
\hline $\begin{array}{l}\text { производство ядөрного матөриала (в } \\
\text { рөакторе) }\end{array}$ & nuclear production \\
\hline произвольная гөомөтрия & generalized geometry \\
\hline промежуточный продукт & intermediate product \\
\hline nponyck & badge \\
\hline $\begin{array}{l}\text { противодөйствие вмөшатөльству } \\
\text { пғ отиводейстеие нарушөнию }\end{array}$ & tamper resistance \\
\hline $\begin{array}{l}\text { проточьный канал дөтөктора } \\
\text { полость дөтөктора }\end{array}$ & detector cavity \\
\hline процедура & procedure \\
\hline
\end{tabular}




\section{MCEA General Gloseary \\ Los Alamos National Laboratory - Translation and Interpretation Service}

Aprit 6. 1995

процедура инспекции

\author{
Процесс \\ Процесс - Пюбоя набор процедр. пршеоднций

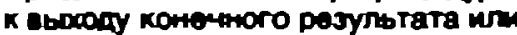 \\ промзапстоу продукта.
}

\section{ПTTO}

Пронзеодственно-технинеский отдеЛ

\section{пункт провоза}

Пункт санкционироеанного проеоза вдерных natopneros.

\section{пункт проноса}

Пункт саншанонированного проноса ндернысх Matepuanos.

путь пөрөключения

ра6очий зталон

crarnapn

$$
\begin{gathered}
\text { равномерное } \\
\text { однородное }
\end{gathered}
$$

радиационный монитор для прохода

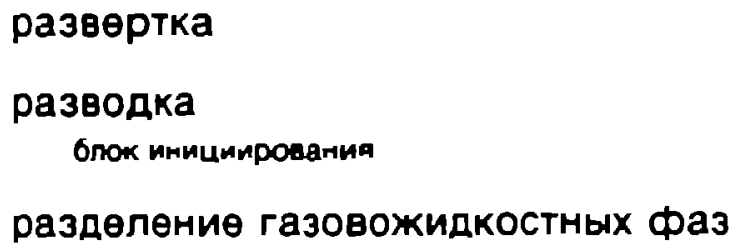

\author{
inspection procedures
}

\section{Process}

Process - Amy set of operations that produces an end result or product

\section{Production Department}

point of transit (vehicle)

Point through which authorized nuclear materials are delrvered to or ahipped from a facility

point of transit (hand delivery) Point through which authorized nuclear materialds are delivered to or shipped from a facility.

diversion path

working standard

uniform

radiation passage monitor

window

initiation block

fluid-fluid phase segregation

Equilibrium chemical composition and possidie

fluid-fluid pnase segregations can nave an

inflience in the total EOS of these mixtures

sampling size

IAEA - Delinizion 24? The number of items which are included in a sample

placement

multiplication

n-utrori multiplication

Jesign of the safeguards approach

cischarge cleaning 


\section{MceA General Gloseary
Los Alamos National Leboratory - Translation and Interprotution Service}

Aprll 6, 1995

pacnan

распределениө

распределитөльная коробка

расслоение

страта

рассматриваөмые области

PO

расстояние, проходимое до детонации

расхождөние

расхождение в данных отправителя и получатөля

расхождение в инвен- тарном количөствө матөриала

расхождөние в инвөн- тарном количөствө матөриала

расхождение по документам мөжду Учөтным КоличөствСМ и фактичөски наличиным количеством ค.м.

расхождение по документам между учөтным количөством и фактичөски наличиным количөством я.м.

РБМК
рөактор большой мощностиб урантрафитный,
кипящий, канөльного типа
рөагировать
рөактив
рөактор
рөактор TRIGA

decay

distribution

junction box

stratum

regions of interest

POHs

run

A proliminary anahris of the data indicates that a $25 \%$ reduction in the pressure predicted for a 25-mm run to detoration in PBX-9502 will decrease the probability of initialion within that distance to $1 \times 10-6$.

discrepancy

shipper/recelver difference

inventory difference

ID

ID

inventory difference

book-physical inventory difference

BPID

BPID

book-physical Inventory difference

LWGR

light water cooled, graphite moderated reactor

react (with)

reagent

reactor

TRIGA 


\section{MCes Ceneral Gloseary}

\section{Los Alamos Matlonal Laboratory - Translation and Interprotation Service}

Aprll 6, 1895

peakTop TRIGA

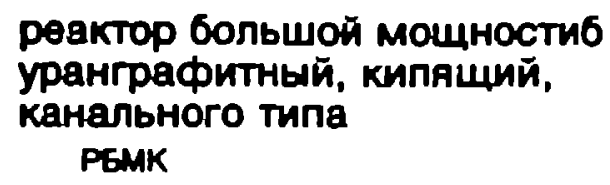

реактор для испьтания материалов

реактор для испьтания материалов

реактор на быстрых нөйтронах

быстрый реактор- разиномотель

рөактор на быстрых нөйтронах

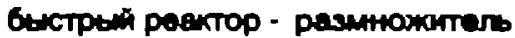

рөактор на кипящей водө

peaкTор РБMK

ревизия

рөгиональный отдөл Министөрства энөргөтики США

рөгиональный отдөл Министөрства энөргөтики СШ'А

рөгистрация нөйтронов

рөгистрировать

считать

пегистрирующие сдвиг часы

рөжим быстрых нейтронов

режим төпловых нөйтронов

рөльсовый пөреключатөль

Ренттенография

PO

рассматриваемые области

российские разводки reactor - TRIGA

light water cooled, graphite moderated reactor

LWaR

materials testing reactor

reactor - materials testing reactor

reactor - fast breecier reactor

fast breoder reactor

boiling water reactor

RBMK reactor

audit

DOE operations office

also: DOE fletd office

DOE field office

also: DOE operations office

neutron detection

count

shift register clock

fast mode

thermal mode

relay switch

$x$-radiography

diagnostics auch as cunductivity pins,

$x$-radlography, stress and strain gauges, lour color pyromeiry, velocity probes.

ROIs

reglons of interest

RIBs 


\section{MC2A Genoral Glossary
Los Alamos National Laboratory - Translation and Interpretation Service}

April 6, 1995

Российский фөдөральный ядөрный центр

POAL

руководящие принципы относительно зкспорта матөриалов и оборудования

руководящие положения, принятые поставщиками ядөрного матөриала и оборудования

РФЯЦ

Российский федерелыный вдерный центр

самоподдерживающаяся

дөтонационная волна

саморазмножение

сборка, крит..ческая

сборка, подкритическая

свөчания Черенкова

сво6одный про6ег

Своевремөнность

сдөрживаниө

согментированное гамма-

сканирующөө устройство

сөрдөчник датчика

синхроимпульс

систөма внутрөннего контроля

система измерений

система информации МАГАТЭ по гарантиям
Russian Federal Nuclear Center

RFNC

material and equipment export guidelines

nuclear supplier guidelines

RFNC

Russian Foderal Nuclear Center

self-sustaining detonation wave

The "pop-plot" for an explosive is a two-parameler quantitative relationship between the initial inpest pressurt and the distance from the input face is the formation of a selt-sustaining dotonation wave.

selfmultiplication

assembly, critical

assembly, subcritical

Cerenkov glow

free path

timeliness

deterrence

segmented gamma scanner

probe core

synch pulse

internal control system

measurement system

IAEA Safeguards Information System 


\title{
Mcen General Gloseary \\ Los Alamos National Laboratory - Translation and Interpretation Service
}

\author{
April 6, 1995
}

\section{Система контроля инвентарного количества адерного матөриала

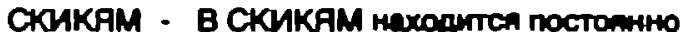

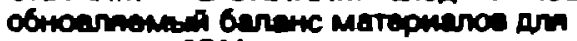

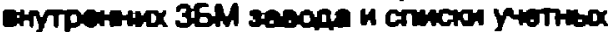

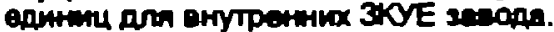 \\ Систөма отчетности о адерном матөриале

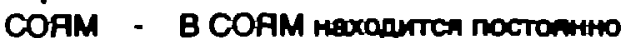

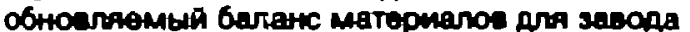

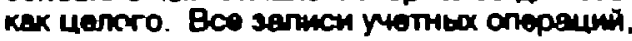

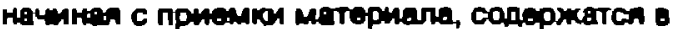 тепуицих Фейлах данtbox. \\ систөма подтверждөния данных отправитөля получателем \\ систөма пространствөнной пасспортизации \\ Вi здрение системы пространстеонно пасспортизеции на одном из сущестоуочих хреннлищ ВНИИЗО. \\ систөма учета и контроля матөриалов (СуиK)}

СУиК упраеляет и контролирует движөние ДМ (дөлящнеся метөриалы)

систөма учета и контроля ядөрных матөриалов

суик

систөма учөта ядөрных матөриалов

систөма(Ы)

систематическая оши6ка

систөматичөская выборка

систөматичөская ошибка

смөщение, отклонение.

систөмы учөта в рамках программы гарантий

Изложенный письменно, Аинамический набор процөдур и правил, разработанных длА Обеспечения целОстности системы учета в рамках программы гарантий

CKaHHGP
Nuclear Inventory Control System

NICS - The NICS maintains a perpetual imventory balence for intarnd plent MBAs and feem listings for Internal piont ICAs.

\section{Nuclear Material Reporting System}

NMRS - The NMPS maintains a perpetual Imventory belance for the plant as a whote. NI transection records since inc eption are maintained in the current data files.

shipper receiver confirmatory system

spatial neutron passportization system

Introduction and placement imto operation of a spatial neutron passportization system at one of the exising VNIIEF storage lacilities.

material control and accounting system; material control and accountability system MC\&A

material control and accounting system controls and monitors the movement of the lissile maierials

material control and accounting system

MC\&A

nuclear material accountancy system NMA system

system(s)

systematic error

systematic sampling

bias

safeguards accountability system

scanner 


\section{MCea Genoral Gloseary \\ Los Alamos National Laboratory - Translation and Interpretation Sorvice}

April 6. 1995

\begin{abstract}
СКИКЯМ

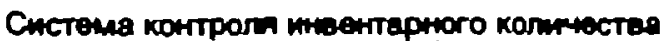

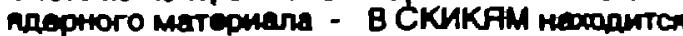

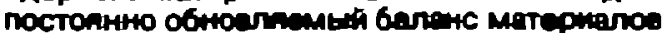

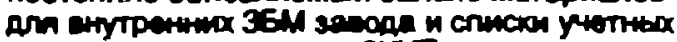

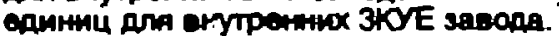

скин-слой

скорость счета
\end{abstract}

.орость счөта нөйтронов

ckpan

случайная ошибка

смөшанныө оксидныө образцы образиы MOKC

смөшаное оксидное топливо MOKC

смөшивание матөриала с различной стөпөнью обогащения

смөщение

отклонение, систөматинеская ошкбKa

Смотритель

хранитель

совпацөния нөйтронов

согласование

имеетса ввиду согласование финансоеых доКументов

согласованность

соглашение

соглашения о гарантиях

corлашение о проенія

содөр.кание компонента в образце по рөзультатам анализа
NICS

Nuclear Imventory Control System - The NICS malntains a perpotual imventory balence for internal plant MEds and item listings for internal plant KCAs.

skin layer

count rate

ratio

neutron count rate

scrap

random error

MOX samples

mixed oxide

MOX

enrichment blending

bias

custodian

neutron coincidence

reconciliatiiion

consistency

agreement

A formal agreement.

safeguards agreement

pro,jet agreement

assay value 


\section{Mces General Gloasary \\ Los Alamos National Laboratory - Translation and Interprotatior Sorvice}

Aprll 6, 1985

coothoweнne

conso

conлo

conоставимость

сопостввление зарегистрированного

и фактичөски наличного количества

сохранения

сохранение материала

сохранөние магнитного потока

сохраняөмыө отходы

COFM

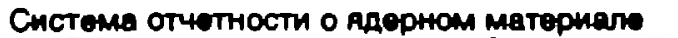

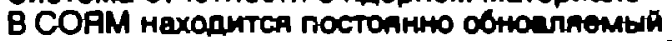
Gananc материалое длғ заsода как целого. Все записи унетных операций, номнан с приемкя материела, содержатся - текуиих файлах данthox.

спекаөмость

спөкающая пөчь

спектромөтрия

спөцальный отчөт

спөциальный вдөрный матөриал

CAM

специальная Физичөская

инвентаризация

спөчөнный диоксид урана

спиральный гөнөратор

список фактичөски наличного количөстөа матөриала

списывание

спонтанно correlation

nozzle, throat

throat, nozzle

traceability

inventory reconclliation

containment

IAEA Glossary Term - i 248

material containment

conservation of the magnetic flux

retained waste

NMRS

Nuclear Material Reporting System - The NMRS maintains a perpotual inventory balance for the

plant as a whote. All transacilon records since

inception are maintained in the current data files.

sinterability

sintering furnace

spectrometry

special report

special nuclear material SNM

special physical inventory

sintered $\mathrm{UO}_{2}$

helical generator

physical inventory ilsting

write-off

spontaneously 


\section{Mcen General Glossary \\ Los Alamos National Leboratory - Transiation and Interpretation Serviso}

April 6, 1995

спонтанно дөлящиөся

среднеө значєние и дисперсия

выборки

средство

Средсте кortpan ДM на KЛП

\section{ссылочная интөгрированность \\ измененип в опном месте влемут изминения в

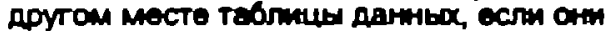

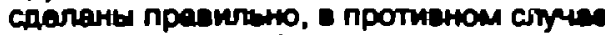

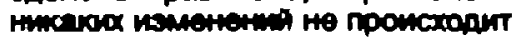

стабилизированный анализаіор. измөритөль

стабилизированньій анализатор, измөритөль

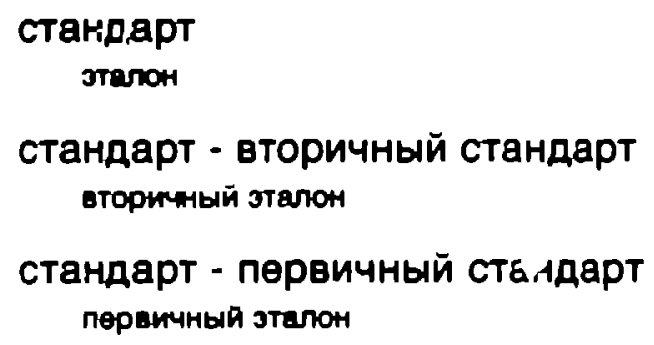

суммарный учөт матөриала spontaneous fission

sample mean and variance

system

Rediation monitoring systems at controlled ecces points. Term includis equipment, trotruments, methods, and even edministrathw procedures.

referential integrity

databasen program Microsoft Access,

Changes done in primary fletds are medo across the whole database for all linked tables, otherwise no changes are mado at all

SAM

stabllized aseay moter

stabilized assay meter

SAM

standard

standard - secondary standard

standard - primary standard

standard deviation (s)

standard error of bias

senior foreman

statistical sampling

stratum

strateglc value

IAEA Glossary - Term \#48

MC\&A system

material control and accounting system

account total 


\begin{tabular}{|c|c|}
\hline \multicolumn{2}{|c|}{ April 0, 1995} \\
\hline $\begin{array}{l}\text { CXema } \\
\text { Grox }\end{array}$ & circuit \\
\hline схөмная плата & circult board \\
\hline сцинтилляционный дөтөктор & scintillation detector \\
\hline СЧөт мНОЖөСТВөнНОСТИ нөйтрОНОВ & multiplicity counting \\
\hline Счөт нөйтронов & neutron counting \\
\hline счөтчик & counter \\
\hline счөтчик, газовый пропорцйальный & counter, gas proportional \\
\hline счөтчик Гөйгөра-Мюллөра & $\begin{array}{l}\text { Geiger-Muller counter } \\
\text { GM counter }\end{array}$ \\
\hline счөтчик Гөйгөра-Мюллера & $\begin{array}{l}\text { counter, Geiger-Muller } \\
\text { GM counter }\end{array}$ \\
\hline счөтчик Гөйгөра-Мюллөра & $\begin{array}{l}\text { GM counter } \\
\text { Goiger-Muller counter }\end{array}$ \\
\hline $\begin{array}{l}\text { счөтчик для инвөтаризацонных } \\
\text { о6разцов }\end{array}$ & counter, inventory sample \\
\hline $\begin{array}{l}\text { Счетчик АЛА топливных сборок } \\
\text { счөтик Аля топливных кассет }\end{array}$ & $\begin{array}{l}\text { fuel bundle counter } \\
\text { tuel assembly counter }\end{array}$ \\
\hline счөтчик инвөтаризацонных образцов & inventory sample counter \\
\hline СчөТчИК МНОЖӨСТВенНОСТИ & multiplicity counter \\
\hline СЧөТЧИК МноЖөСТВөНнОСтөЙ & counter, multiplicity \\
\hline $\begin{array}{l}\text { Счетчик МножөствөннОСТИ, } \\
\text { пирохимичөский }\end{array}$ & counter, pyrochemical multiplicity \\
\hline счөтчик нөйтронных совпадөний & neutron colncidence counter \\
\hline счөтчик нөйтронных совпадөний & counter, neutron coincidence \\
\hline $\begin{array}{l}\text { Счөтчик нөйтронНЫХХ совпадөний, } \\
\text { өысокопоточный }\end{array}$ & counter, high-ievel neutron colncidence \\
\hline & HLNCC \\
\hline счөтчик совпадөний & coincldence counter \\
\hline счөтчик совпадөний & counter, coincidence \\
\hline
\end{tabular}


Los Alamos National Lebosatory - Translation and Interprotation Sorvice

April 6, 1995

счөтчик совпадөний, активный колодезный

\author{
СЧөТчИК С ПОСТОяннОЙ \\ зффектмөностью при разных \\ положениях и энергиях нейтронов \\ считать \\ pernctpwposatb \\ сырьөвой матөриал \\ CPM \\ специальнй яһерный материал \\ табліетка \\ таймирование \\ Средстев таямированип и слөжөния 39 \\ маршрутван. \\ ТВЭЛ ('өпловыделающий элөмөнт) \\ твал \\ төкущеө зарөгистрированное \\ количөство матөриала \\ төлөсный угол \\ төпловыдөляющий элөмөнт \\ TBOת \\ төрмичөский \\ TECT
}

испьтанне

төст качөства

испытание качөсть

Төст качөства

испитание качесіва

төст количөстеа

иситтание количөстев

Төст количөстөа

испытанне количестеа

төхническое заключөние counter, active wall coincidence

AwCC

Flat-Squared Counter

count

ieed matorial

SNM

special nuclsar materiol

pellet

timing

Timing and routing control systems.

fuel rod

...fuel rods that make up a tuel assembly. sometimes referred to as a tuel eternent.

running book inventory

solia angle

fuel rod

...fuet rods that inake up a fuel assermbly; sometimes referred to as a fuel element.

thermal

test

test - attributes test

attributes test

test - variables test

variables test

technical conclusion 


\section{MceA Gemeral Gloaeny
Los Aamos National Laboratory - Trensiation and Intorprotution Sorvice}

April 6, 1995

\author{
төхнолог цеха \\ Төхнолотичөский отдел \\ TO
}

тиражированиө

TO

Twoнnorm+çой отдал толщина плакировки для топливных
стөржнөй

топливная 6ә-арея

топливная пластина

топливная подсборка

ivм стерожень

топливная сборка

мли толлиный пакет

топливная сборка

прмимер выпускаемого прадукта

топливный стөржөнь

или подсборка

топливый элөмөнт

торий

точность

ТСчность

точность Иэмерения

трансмутация

транспортный портал

трөбования систөмы гарантий

... ПопХод, нохопАшиИС - СОотоетСтеии С

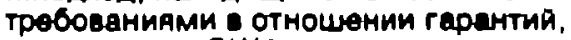
ПринАтЫMH — США

тренировка

обучение

тройник

тру6а shop production engineer

Production Engineering Department

small-scale production runs

Production Engineering Department

cladding thickness for fuel rods

fuel cell

fuei plate

fuel rod

or subasembly

assembly

fud assembly

fuel assembly

an example of a product shipment

fuel rod

or subassembly

fuel element

thorium

accuracy

precision

accuracy of measuremerit

transmutation

vehicle portal

safeguards requirements ... an approach mesting U.S. saleguards requirements

training

$T \cdot$ connector

armature 


\section{uces Genoral Gloseary \\ Los Alamos National Laboratory - Translation and Interpretation service}

April 6, 1995

тругноизмеряемый скрап

тяжелая вода

тяжөловодный рөактор

тяжөловодный рөактор

тяжөловодный рөактор

тяжөловодный рөактор

увөдомлөниө

удаленные пру зачисткө матөриалы

узөл отключения

укорачивать

улучшөнный ядерный матөриал

умолчания

униакльная идент.1Фикация

(установки)

упакованный

гөрмөтиз Арованный, запөчатанный

управлаюощий модуль

уран

уран - өысокообогащөнный уран BOY

уран - низкообогащөнный уран HOY

уран - природный уран difficult-to-measure scrap

heavy water

HWR

heavy water reactor

reactor - heavy water reactor HWR

HWR

heavy water reactor

heavy water reactor

HWR

notlfication

clean-out materials

crowbar

shorten (verb)

improved nuclear material

default

unique identification (facility)

sealed

calıned

supervisor module

uranium

uranium- highly enriched uranium HEU

uranium - low enriched uranium

LEU

uranium - natural uranium 


\section{MceA General Gloasary
Los Aamos National Laboratory - Tranalation and Interpretafion Service}

April 8, 1895

\begin{abstract}
урановыг̆ козффициент

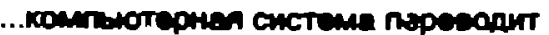

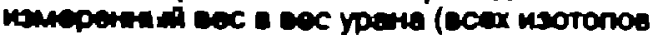

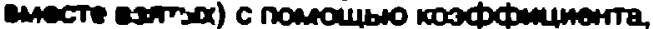

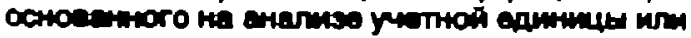

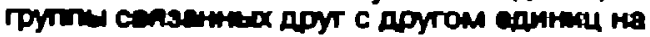
содеросанше чистого урана или с помоиныо козффициента урана
\end{abstract}

уровень значимости

уровень предутреждения

предел для прадурежденмн

усиление

усилитель

усовөршенствованный

газоохлаждаөмый рөактор

усовөршенствованный газоохлаждаөмый рөактор

усовөршөнстеованный газоохлаждаөмый рөактор

устанЈвка

Тармин МАГАТЗ

установка

Яено не В іКнимении термина МАГАТЭ -

'/зготоаление и тестирование

зКспериментальтиго образча устаноек' А АлА

контроля сохранности кпнтөйнерое

установка, криткчөская

установка с ядерным материалом в видө прөдмөтов

уста;нвки с матөриалами в

балк-формө

устойчивость

устройство

устройство для сохрания и наблюдөния element factor (uranium)

...the measured woigtits are converted by the computer besed system to welohts of uranium clement by apphing a specific element factor besed on the uranium aseary of the Hem or tot or by supphying a uranlum-ebmont factor

significance level

warning limit

gain

aniplfier

advanced gas cooled reactor

AGP

reactor - advanced gas cooled reactor AGR

AGR

advanced gas cooled reaclor

facility

unit

Devotopment and testing of a model of a unit to monitor the integrity of combiners with flesile materials

facility, critical

item facility

bulk handling facilities

immurity

derive

C/S device

containment/surveillance 


\section{mcen General Gloseary \\ Los Alamos Netional Laboratory - Transiation end Iriterprotation 8-vice}

April 6. 1995

\section{устройство для сохрания и на.Олюдөния}

устройство рөгистрирующөө
вмөшатөльство (наружөниө)

устройство регистрирующее

вмөшатөльство (нцружение)

уточнение

учет

ччет материала в почти рөальном масштвбе врөмөни

учет матөриала в почти реальном масштабе времөни

учет материала в почти реальном масштабе времени

учөт матөриалов

учөт ядөрного материала

Учөтная өдИница

В рамках МАГАТЭ или инвентаризации для CYnK

\section{учөтная өдиница}

aппаряту, жые средства контроля уеттых өдинид с адерныряи материалами

\section{учөтная запис'}

Учөтноө Измөрениө

Измерение, данмые которого могут использоватьСА АЛА учета

учөтныө документы

матернально - балансовые уметные доқументы

учөтный баланс материала containnient/surveillance device

CSS device

tampering indicator device

TID

TID

tampering indicator device

adjustment

accounting

NRT

neer roaftime material accountancy

near real-time material accountancy

NRTA

NATA

near reat-time material accountancy

mateilal accountancy

nuclear material accounting

item

In IEA or MC\&A inventory terms

item

Instrument - based monitoring systems for items containing nuclear materials. Russian literally means : ITEM OF ACCCUNT

account

accountability measurement

Measurement data that may be used for material accounting.

accountina records

account balance 


\section{Mean General Oloasary \\ Los Alemos Netional Leoratory - Translation and Interprotution Eervice}

April 6, 1905

\author{
Файл рөгистрачии \\ Фактнческое наличное копичество \\ Matepkana

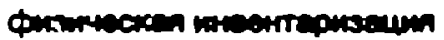 \\ Фактическое наличное количество \\ Matepuara \\ 中uamucecan mientrapuseuman \\ Фактнческая инвентарная разность

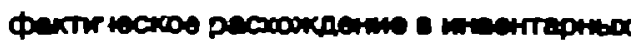 \\ колиместеQх мatepuara \\ фактор разрешения различных масс

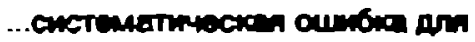

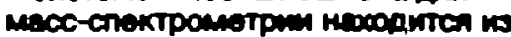

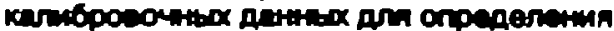

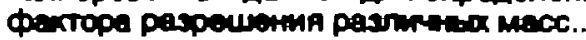 \\ Физико-Энергетический Институт \\ Ф3И, 06rantwx \\ физичөская защита \\ физичөская инвөнтаризация \\ Фактиеское наличное колинесте матернала \\ фоновая рассматриваемая о6ласть

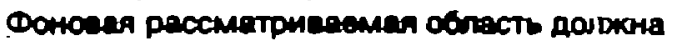

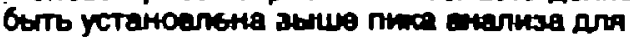 \\ вьмита фона под пиком. \\ фоновые нөйтроны \\ формирующий \\ ФЭท \\ Oизико-Знортетниестай институт. Обнинск
}

химичөский анализ

хищөниө

холодные участки скопления

Отложения в такмх трубах момхот 6ыть ОТнОсительно ОднорОДНьм По Алине или может иметь горачие (загрАзненшь) или холюдние (чистые) учестки скопления, - sеиисимости от реального механизма образсания отложений

хранитөль

смотритель factor log

physical inventory

P

PI

physicad inventiony

actual imventory difference

\section{mass discrimination factor}

...the oy tematic error for the mass spectrometr is dertved from the cellibration data for determining the mass discrimination factor...

Institute of Physics and Power

Engineering

IPPE, Obninak

physical protection

physical inventory

PI

background region of interest

A background regicil of interest must be set abowe the assar/ peak to subtract the continuum under the peak.

backgrcund neutrons

shape(d)

IPPE

Institute of Physics and Power Engineering, Obninsk

chemical analysis

theft

cold spots

The holdup in these plpes may be relattvely univerm with length or it may show hot spots or cotd spots, depending on the actual ahotdupmechanism.

custodian 


\section{MarA Ceneral Oloasary \\ Los Alamos Mational Leborationy - Tianalation and Interprotition service}

Aprt 6, 1905

\author{
хранитель ядерных материалов \\ целевые количества \\ цели оОнаружения МАГАТЭ
}

центральная заводская лаборатория
цзл

Центральная инвөнтаризационная комиссия

цөнтральная станция

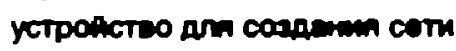

ЦЗЛ

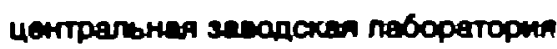

циркалой (сплав)

число нөйтронов в Функции массы

число рөальных нөйтронов в актах совпадений

шаговый двигатөль

шафлер на основө калифорния 252 (252 Cf)

шлак

шлифовальная установ::а

штрих-коды

штрихивой код

бар кар

эквивалент нагрузки

экономист цөха

экран

экспөримент на инженерном уровнө

эксплуатационные учетныө

документы

записи nuclear materials custodian

goal quantities

IAEA detection goals

\section{Central Plant Laboratory}

Central Imventory Commission

hub

computer nutwork

Central Plant Laboratory

zircaloy

reals vs mass

reals

stepping motor

callfornium ${ }^{252}$ shuffler

tails

grinder

bar-codes

barcode

dummy load

shop economist

shield

engineering scale experiment

opeiating records 


\section{ment Caneral Olowary \\ Los Alamos Mational Leboratory - Trenalation end Interpretation servico}

Aprt 6, 1005

\section{зксплуатационны отчет \\ зксплуатация Адерных установок \\ электронные модули преобразования имтульсов}

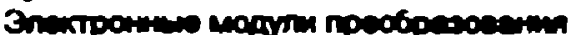

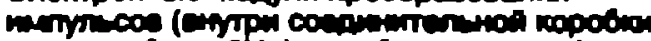

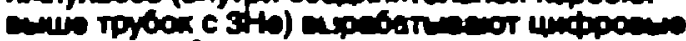
minguces, of conoes

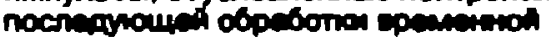
coppen une u cromex cries.

Змиссия нейтронов

Знергетический реактор, останавливаемый для перегрузки топлива

энергетический реактор, пөрегружаөмый на мощности

ॐэргөтичөский реактор, останавливаөмый для пөрегрузки топлива

энөргөтичөский рөактор, пөрөгружаөмый на мощности

энөргия
энөргозффөктивность
эталон

cтанnapn

эталон - рабочий эталон

рабочнй стандарт

эталон - пөрвичный эталон

перенчный стандарт

эталон - өторичный эталон

өторичный стандарт

эталон вөса

эталонный материал

этикетка operating report

facility operations

pulse-processing electonics modules

Puteoproceseding electonice modube ( hatde the unction bou bow the 3th tubes) produces digital

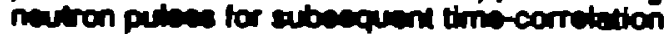
procesing and counting chreitt.

neutron emission

off-loaded fueled power reactor

on-loaded fueled power reactor

reactor - off-loaded fueled power reactor

reactor - on-loaded fueled power reactor

energy

energy efficiency

standard

standard - working standard

standard - primary standard

standard - secondary standard

standard weight

reference material

sticker 


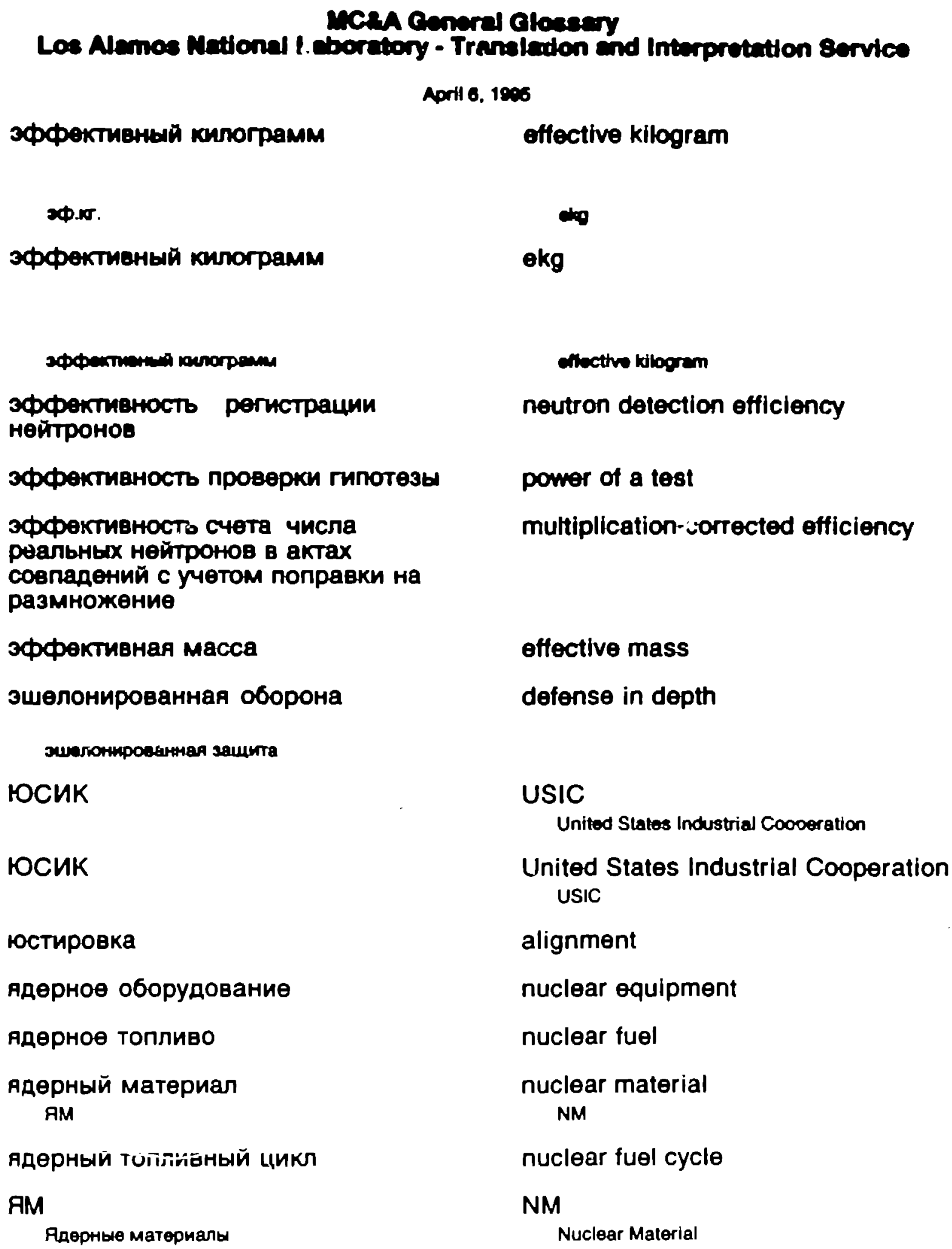




\section{ENGLISH - RUSSIAN GLOSSARY}

MCeA Gonoral Glossary - ACRONYMS

Los Alamos National Laboratory - Translation and Interpretation Service

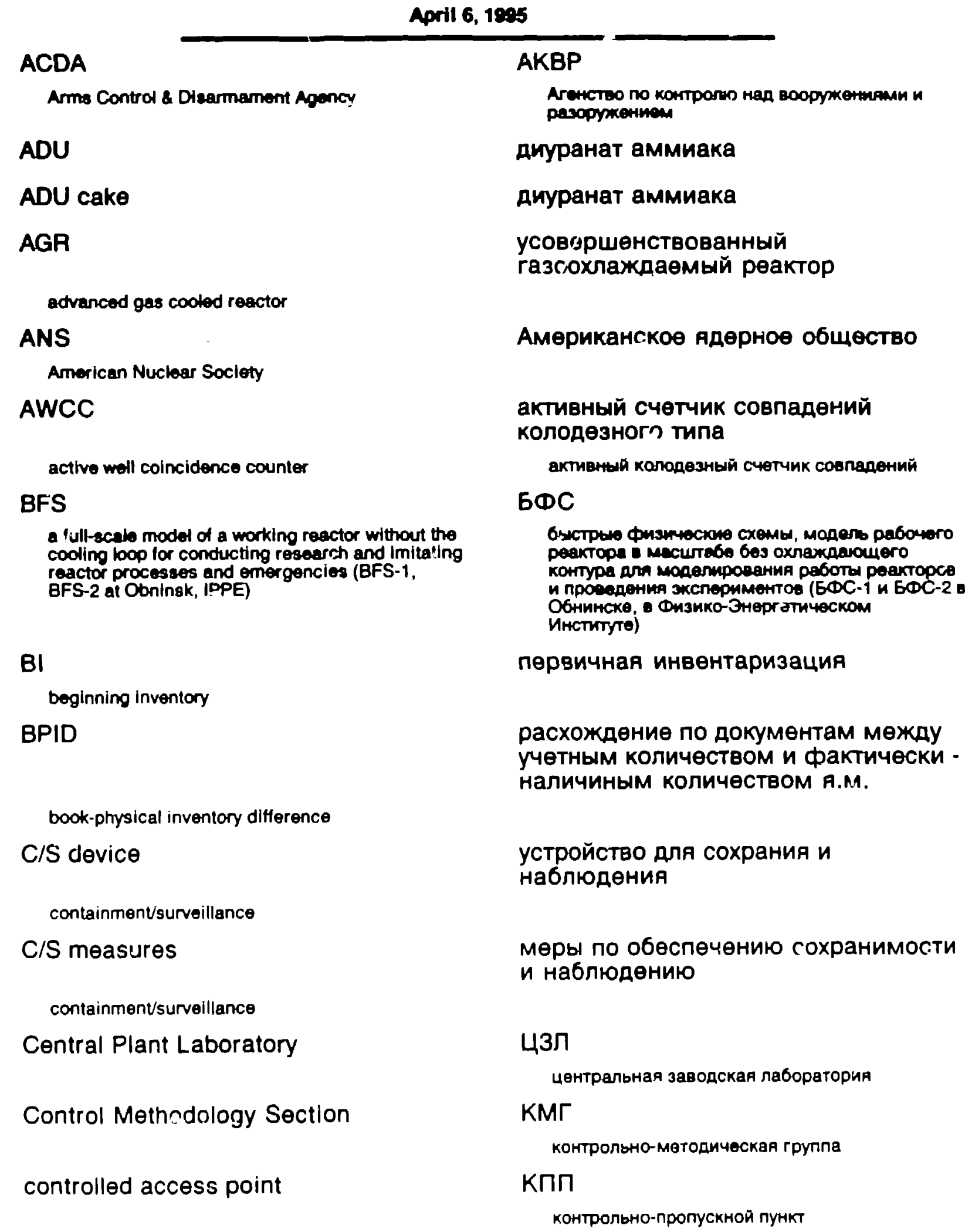


Los Alamos Mational Laboratory - Translation and Interprotation Service

April 6, 1905

CRM

centified reference material

CUSUM

Curnulative surnmation (of the materiol balance)

ekg

effective kllogram

ESARDA

European Safeguards Research and Dovotopment Aseociation

FM

fisalle material

fuel rod

...ful rods that make up a fuel assembly. somelimos reterred to as a fuel element.

FWHM

Iull whtth at half maximum - Record the full width at half maximum and half width of the radial response al this dislance.

GM counter

Geiger-Muller counter

HEU

highly enriched uranium

HLNCC

high-level neutron colncidence counter

HRGRS

high resolution gamma ray spectromelry

HTGR

high temperalure gas cooled reacior

HWA

heavy water reactor аттөстованный эталонный матөриал

Кумулятивная сумма погрөшностөй измерөния

अффективный килограмм

3ффектиеннй килотрамм

Европөйская Ассоциация

Исследоватөльских и

Oпытно-Конструкторских Рa6ot по

Гарантиям 6әзопасности

ДМ

делf tнoch Matepmarta

ТВЭЛ (төпловыдөляюц'!ий элөмөнт)

Tean

полная ширина на половинө максимума

Зарегистрируйте полную ширину не полоеине максимума радмельного откликв на зтом расстопнини.

счөтчик Гөйгөра-Мюллөра

BOY

өысокообогащөнный урян

нөйтронный счөтчик совпадений с высокой скоростью счета

гамма-спектромөтрия высокого разрөшөнния

высокотемпературный

газоохлаждаөмый реактор

тяжөловодный рөактор 


\section{Los Alamos Mationsl Laboratory - Translation and Interprotation Borvice}

April 6, 1806

HWR

heavy water reactor

HWR

heavy water reactor

IAEA

International Atomic Energy Aoency.

The containere are tested in eccordance with LAEA requirements for strength againat the exteml factors that are typtcal of sertous transportation eccidents.

ICA

The Hem control aree (ICA) atructure is deslgned to provido maximum imventory and administrative control over all materiabs not in an Immediate proceasing status and over all items amenable to item control.

ICR

inventory change report

ID

Inventory alference

inventory KMP

key measurement point

IPPE

Institute of Physics and Power Engineering.

Obninsk

IPS

International plutonium storage

ISTC

International Science and Technology Center

KMP

key measurement point - locatione where nuclear material appears in such a form that it may be measured to determine material flow or inventory

\section{LEMUF}

limit error of material unaccounter for - In the U.S., the nead for a certain minimum measurement quality is specilled by nimerical values for the limit of error of MUF (LEMUF). тяжөловодный рөактор

тАжөловодный реактор

\section{MATATO}

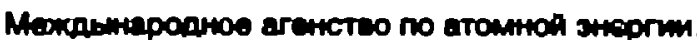

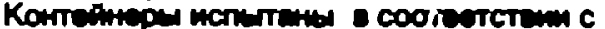

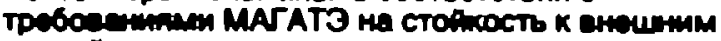

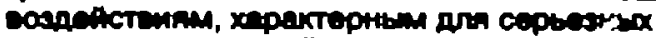

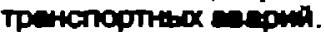

\section{зона контроля учөтных өдиниц}

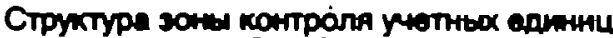

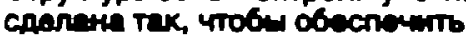

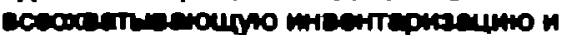

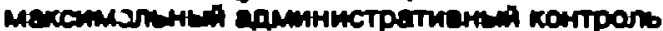

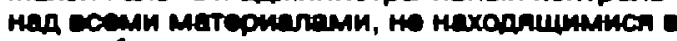

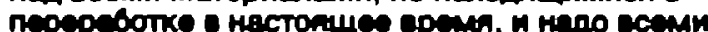

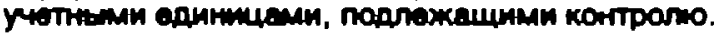

отчет 06 изменениях инвентарных количөсте матөриала

расхождение в инвен- тарном количестеө матөриала

Ключевая точкя измерөнИА

\section{ФЭท}

Физико-Энергетинескй Институт, Обнинск

MX几

международное хранение плутония

MHTL

Мождународный Научно-Төхничоский Цонтр

KTИ

kлnочеsen то4ka нзмеренил - места, где пдерный матермал предстарпен — такоЯ̆ форме,

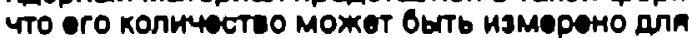
устанолления потока материала или ого инсентарнHог колінесте

\section{ПOKHM}

предеп оши6ки количестеа неуттенного материеле - I США неОбХОДимОСТЬ ПрИнनтиन опреде, Юенного минимельного качестеа измерения определена численншми значениями дाา предела оши(JKh KHM (ПОКНM) 


\section{Los Alamos National Laboratory - Translation and Interprotation Service}

\section{April 6, 1995}

\section{LEU}

low enrlched uranium

\section{LWGR}

llght water cooled, graphite moderated reactor

\section{LWR}

light water reector

\author{
MAA \\ material access area \\ MBA \\ material belance area \\ MBP \\ meterial balance period \\ MBR \\ material balance report \\ MC\&A system \\ material control and eccounting (MC\&A) system \\ controls and monitors the movement of the fisslle \\ materiab
}

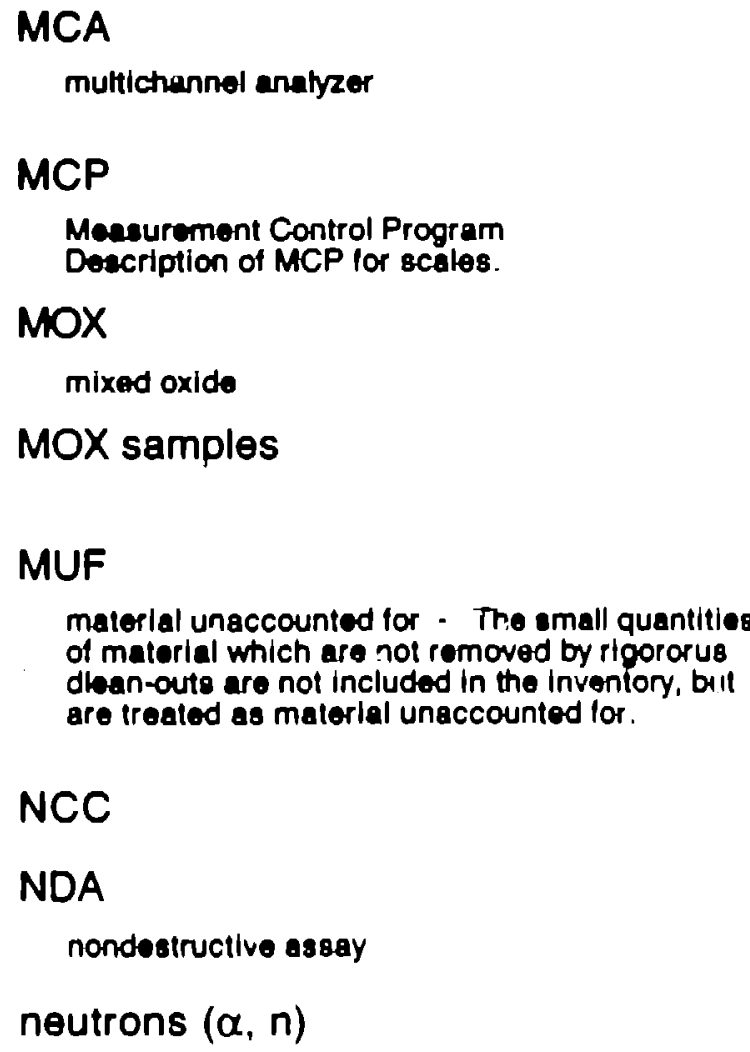

MCA

multichannel anatyzer

MCP

Measurement Control Program

Description of MCP for scales.

MOX

mixed oxide

MOX samples

\section{MUF}

material unaccounted for - The small quantities of material which are nol removed by rigororus dban-outs are not included in the inventory, by Il are treated as materlal unaccounted lor

NCC

NDA

nondestructive essay

neutrons $(\alpha, n)$

HOY

низкооботаценный уран

\section{PБMK}

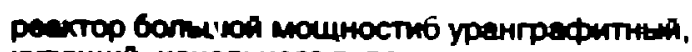

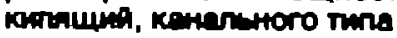

легководный рөактор

зона доступа к материалу

उБM

3oma Garanca matepuara

ПБМ

пернод беланса метериала

матөриально-балансовый отчөт

CYuK

система учета и контроли пдерные матермалов (CYuK) упранлает и контралируот декокение ДМ (делғчиеся матерналы)

MKA

много-канальны анализатор

программа контроля измерений

Описание программы контрола измерения̆ для secos.

MOKC

сменаное оксияное топливо

смөшанные оксидные образцы

ópasub MOKC

KHM

количестео неучтенного материела - Малые Колнчестеа материала, не удаленные

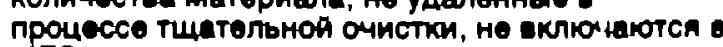

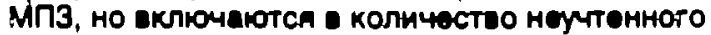
матернала.

нөйтронные счөтчик совпадөний

HPA

нерезрушагоций анализ

нөйтроны, испускаөмыө в рөакции

$(\alpha, n)$ 


\section{MCeA Goneral Oloasary - ACROorrms \\ Los Alamos National Laboratory - Translation and Intorprotation Service}

Aprll 6, 1996

\section{NICS}

Nucleer Imventory Control Syatem - The NICS malntains a peppetial trumentory balance for internal plent Mads end hem thetinge for internal plert KCAs.

NIM

nucied Instrument moduio

NM

Nuchar Material

NMA system

nucker material accountancy orstem

\section{NMRS}

Nucteer Material Reporting Syetem - The NMAS malniains a perpetud imventory batence for the plant as a whole. Al transection records eince inception are maintained in the current data files.

NOL

normal operations loss

NPT

Non-Proliferation Treaty

NAC

Nuclear Regulatory Commiseton

NAT

near real-tlme materlal accountancy

NRTA

near real-time material accountancy

Pi

phyoical inventory

PMCA

portable multichannel analyzer

Production Department

Quality Control Department

\section{CКИKЯM}

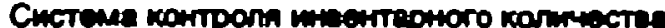

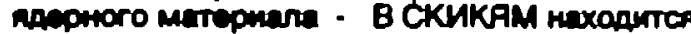

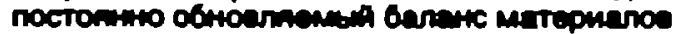

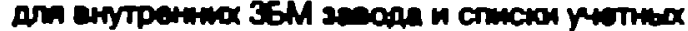

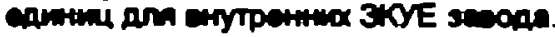

модуль ядерного прибора

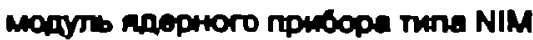

FM

Rhopнere matepmand

практика учета ядерных матөриалов

\section{COAM}

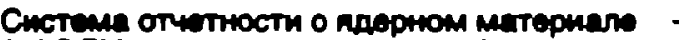

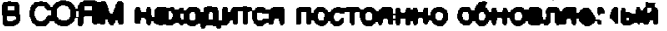

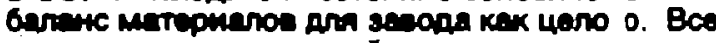

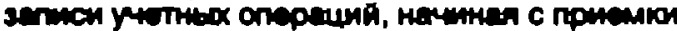
Matepuara, conepsaton a renyuro dabrex garisox.

обычныө производствөнные потөри

Договор о нөраспрос- транөнии ядерного оружия

НРЦ

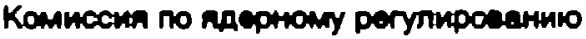

учөт матөриала в почти рөальном масштабе времени

учөт матөриала в почти рөальном масштабе времөни

фактическое наличное количество матөриала

фнзическал иненттаризация

портативный много-канальный анализатор

ПTO

Пронзеодстеенно-техонческиЙ отдел

OTK 


\section{Los Alamos National Laboratory - Translation and Interpretation Sorvice}

Aprll 6, 1995

\section{RFNC}

Russian Fedoral Nuctear Center

ROls

regions of Interaet

SAM

stabllzed asary mater

SNM

opecial nuchar material

so

stoniflcant quantity

SSAC

Stats Syatem of Accounting and Control

T - connector

TID

tempering indicator device

TRIGA

USIC

Unlted States Industrial Cooperation

\section{PФRL}

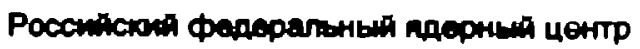
PO

peccusatpuresumin obrecty

стабилизированный анализатор, измеритель

CAM

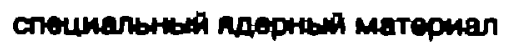

3K

значимое колиместео

ГСУик

Государстенная система унета и контроля

тройник

устройство рөгистрирующөе

вмөшатөльство (наружөние)

peakTop TRIGA

юCUK 


\section{РУССКО - АНГЛИЙСКИЙ ГЛОССАРИЙ}

MCeA Goneral Glossary - ACRONYMS

\section{Los Alamos National Laboratory - Translation and Interprecation Service}

6 April, 1905

\begin{abstract}
AKBP

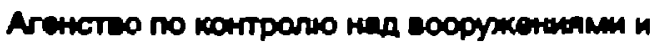
pesoprowatum

активный счетчик совпадөний колодезного типа

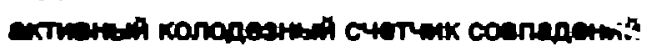

Американское адерное рбщество

аттөстованный этөлонный матөриал

\section{БФC}

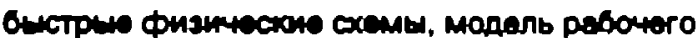

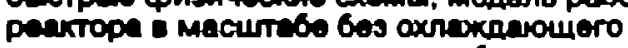

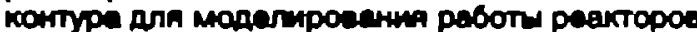
и nposenewha skcnepuanowToe (БФC-1 и БОС-2 a Obnumexe, \& Disuno-3hepretumeckom Институть)

BOY

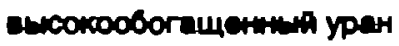

высокотөмпературнЕй газоохлаждаөмый рөактор

гамма-спектрометрия высокого разрөшөнния

ГСУик

Государстенная системе учета и контроля

диуранат аммиака

диуранат аммиака

ДM

делคщиесп матернвли

Договор о нераспрос- транении คдерного оружия

Eвpoпейская Ассоциация

Исследоватөльских и

Oпытно-Конструкторских Работ по

Гарантиям 6езопасности
ACDA

Ams Control \& Dlaurmement Agency

AWCC

ective mell coincidence counter

ANS

American Nuclear Society

CRM

certfied relerence materlal

BFS

a fultecale modet of a working reactor without the cooling loop for conducting research and imltating reactor proceanes and emergencies (BFS-1, BFS-2 of Obninak, IPPE)

HEU

highty enriched uranlum

HTGR

hlgh temperature gas cooled reactor

HRGRS

Figh resolution gamma ray spectrometry

SSAC

State System of Accounting and Control

ADU cake

ADU

FM

fiesile material

NPT

Non-Proliteration Treaty

ESARDA

European Safequards Rusearch and Development Assoolation 


\section{Los Alamos National Leboratory - Translation and Interprotation Service}

April 6, 1905

3БM

soma banarca matepuana

$3 K$

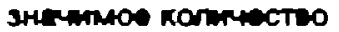

зона доступа к матөрь:алу

зона контроля учөтных өдиниц

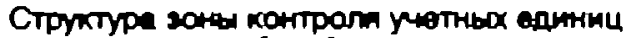

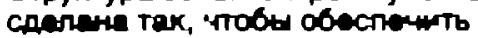

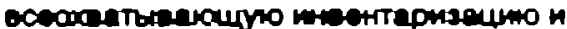

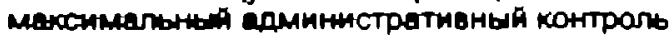
над всеми метермелемн, но находящиниса в пороработіс е нестолще еремл, н надо всеми

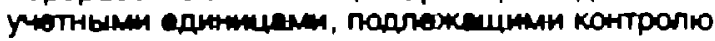

ключөвая точка измөрения

KMI

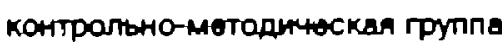

\section{KHM}

калинесте нелтенного матернала - Maлto количесте метернала, не ураленные а

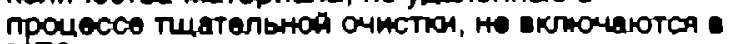

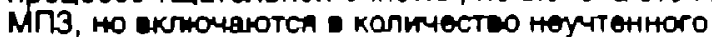
Matopmana.

$\mathrm{K} \Pi$

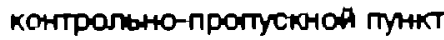

KTH

kлюнеeas точkе измерения - места, где пдерный метернел продстален О такоЯ форме, что еГо КоЛнчестео может бЫть нзмерено длА устаноал⿻нин потока матернала или өго

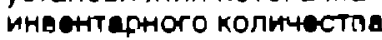

кумупятивная сумма погрешностөй ИзМөрөния

лөгководный рөактор

МАГАTЗ

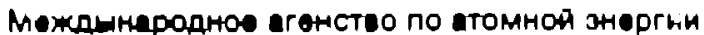

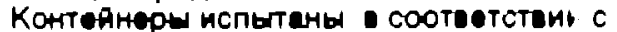
требоеаниями МАГАТЭ не стоЯкость К Фношним ооздөЯстонАм, характөрным дла серьезных транспортнық арарня.

матөриально-белансовый отчөт
MBA

material balance area

SR

signiflcant quartity

MAA

material accose arey

ICA

The Item control arce (KCA) etructure is designed to provide maximum imventory and administrative control over all materiale not in en immodiato processing status and over all Items amenable to flem control.

inventory KMP

koy meas urement point

Control Methodoiogy Section.

MUF

materlal unaccounted for . The smal, quantitles of material which ere not remuved by rigororus dlean-asts are not included in the imventory, but are traled as material unaccounted for

controlled access point

KMP

koy measurement point - locations where nuclear material eppare in such a form that it may be mesesured to dotermine material flow or inventory

\section{CUSUM}

Cumulative oummation (of the material balance)

LWF

light water reactor

IAEA

International Atomic Energy Agency

The containers ape teslod in eccordance with IAEA requirements for etrength againat the uxternal lactore that are typlcal of serious transportation accidente.

MBR

material balance report 


\section{MCRA Genoral Glosenry - ACRONYMS \\ Los Alamos National Laboratory - Transiation and Interpretation Service}

April 6, 1995

мөғ : по обеспөчению сохранимости и наблюдению

MKA

много-ханалыный анализатор

MHTL

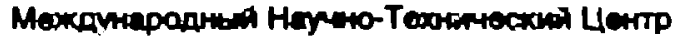

модуль ваерного прибора

модуль ядерното прибора тma NIM

MOKC

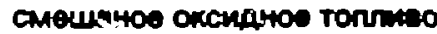

MXก

международноя хранонио плутония

нөйтроннщй счөтчик СОвпадөний с Высокой скоростью счета

нөйтронные счөтчик совпадений

нөйтроны, испускаөмыө в рөакции

$(\alpha, n)$

HOY

низкообогащенный уран

HPA

неразрушающий амелиз

HPL

Комиссия ПО адерному реГУЛнарованию

обычные ппоизводствөнные потөри

OTK

ОТчет О6 измөненияХ инвентарныХ количөств матөриала

ПБМ

пөриод баланса матернала

Пөрөичная Инвөнтаризация
C/S measures

containmentsurvelliance

MCA

muttictiannel analyzar

ISTC

International Sctence and Technology Center

NIM

muclear instrument module

MOX

mixed oxide

IPS

international phitonium stor age

HLNCC

high-fevel neutron coincidence counter

NCC

neutrons $(\alpha, n)$

LEU

low enriched uranium

NDA

nondestructive assay

NRC

Nuclear Regulatory Commission

NOL

normal operations loss

Quality Control Department

ICR

inventory change report

MBP

material balance period

BI

beginning inventory 


\section{mCen Gonoral Gloseary - ACROWYMs \\ Los Alamos National Leboratory - Transiation end Interpretation Service}

April 6, 1986

\section{ПОКHM}

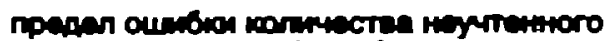

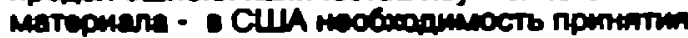

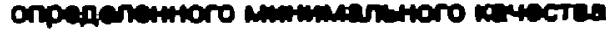

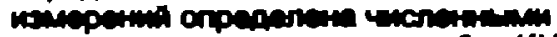

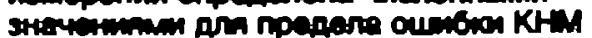
(TOKHM).

\section{полная ширина на половине \\ максимума}

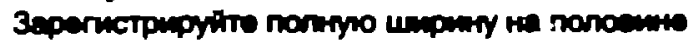

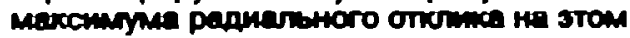
pacctomine.

\section{портативный много-канальный анализатор}

практика учөта ядерных матөркалов

программа контроля измөренкй Описени программы контроли измерений для cocos.

ПTTO

Промзеодстеонно-техониески отдал

расхождение в инвен- тарном количөствө матөриала

расхождение 110 докумөнтам мөжду учөтным количөством и Фактичөски наличиным количөством ค.м.

\section{PEMK}

реактор большсА мошностиб уренгрефитный, Кнпящий, Канального типа

\section{рөактор TRIGA}

PO

рассматриеаемые области

РФЯЦ

Российския федеральный пдерный центр

\section{CKИКAM}

Система контрола инеентарного количества nдерного материала - В СКИКАM находитсп постолнно обноалпемш баланс материалое

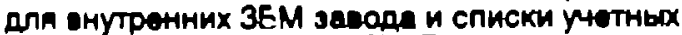
өднниц ФНА внУтренних ЗКУЕ замода.

\section{LEMUF}

Hint error of materlal uneccounted for - in the U.S., the nead lor a certain minimum messuremont qualty ts epocitied by nimerical values for the limit of error of MUF (LENUF)

\section{FWHM}

full with at half meximum - Record the full width at hat maximum end hali width of the redial response at this distance.

\section{PMCA}

portable multichannel analyzer

NMA system nuclear inaterial accountancy system

MCP

Measurement Control Program Description of MCP for ecales.

\section{Production Department}

ID imventory difference

\section{BPID}

book-physical inventory difference

\section{LWGR}

light water cooled, graphite moderated reactor

\section{TRIGA}

\section{ROls}

regions of interest

\section{RFNC}

Russian Federal Nuclear Center

\section{NICS}

$$
\begin{aligned}
& \text { Nuclear Inventory Control System. The NICS } \\
& \text { maintains a perpotual inventory balance for } \\
& \text { internal plant MBAs and item listings for internal } \\
& \text { plant ICAs. }
\end{aligned}
$$




\section{ICeA Generd Oloseary - ACROWMMS \\ Los Alamos National Leboratory - Trensiation and Interpretation Service}

April 6, 1995

\author{
смөшанные оксидные образцы \\ осравиы MOKC
}

\section{CORM}

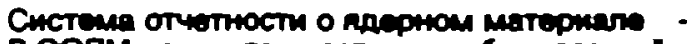

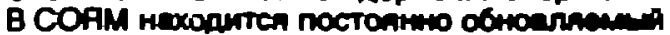
Gerianc matepuarion ana sasone kak uenoro. BCe

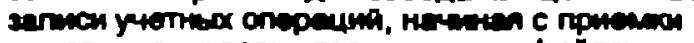

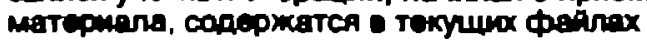
Agmax

стабилизированный анализатор, измеритөль

\section{CУиK}

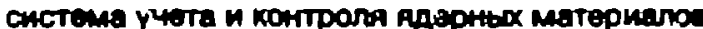

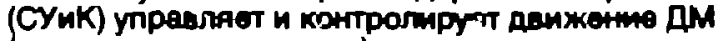
(дептциеса мaтөриant)

счөтчик Гөйгөра-Мюллөра

CAM

специальный вдернтый метериел

ТВЭЛ (төппоеыдөляющий элөмөнт) твзл

трсйник

тяЖөловодный рөактор

тяжөловодный рөактор

тяжеловодный рөактор

усовершөнствованннй газоохлаждаөмый рөактор

устройство для сохрания и наблюдения

устройство рөгистрирующеө вмөшатөльство (наружөние)

\section{MOX samples}

\section{NMRS}

Nuctear Material Reporting Syetem - The NMPS maintains a porpetula imvemiony balance tor the plant as a whole. Alt transection record; atnce inc ption are maintained in the currern' data files.

\section{SAM}

stabilized assay meter

\section{MC\&A system}

material control and accounting (MCsA) system controts and monitors the movement of the fissile materials

\section{GM counter}

Geiger-Muller counter

\section{SNM}

special nuclear material

fuel rod

..tuel rods that make up a fuel assembly; somellimes referted to as a fuel element.

$T$ - connector

HWR

heavy water reactor

HWR

heavy water reactor

HWR

heavy water reactor

AGR

advanced gas cooled reactor

C/S device

containment/survelliance

TID

tampering indicator device 


\section{mcen Ceneral Closesy - ACROWYis \\ Los Alanos National Laborationy - Tramaliation end Interpretition Eervico}

Aprt 0, 1905

унет материала в почтм реальном масштабе времени

учет материала в почти реальном масштабе врөмени

Фактическое наличное количество матөриала

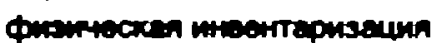

Ф७ท

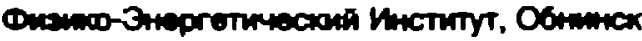

цзл

централыная з68одская лаборатория

зффективный килограмм

зффектианый килотремм

юсик

FM

Rдернын матөриалы
NRT

new reat-the materled eccountancy

NRTA

neer real-time materied eccountency

PI

physical imventory

IPPE

Inotterte of Physics and Powner Enginaering. Obninsik

Central Plant Laboratory

$\theta k g$

effectivo kilogram

USIC

United States Industrial Cooperation

NM

Nuclear Materlal 